
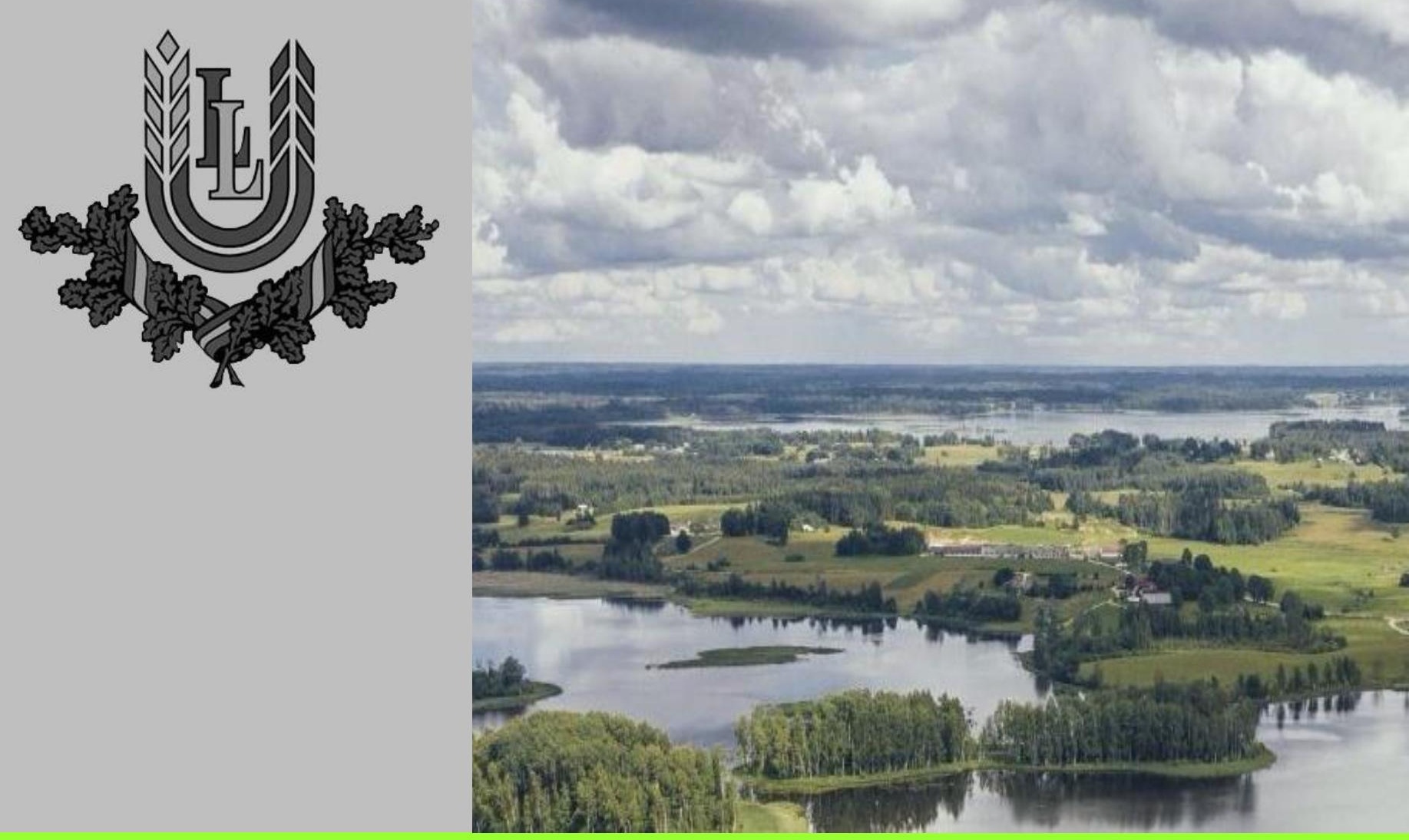

\title{
LANDSCAPE ARCHITECTURE AND ART
}

SCIENTIFIC JOURNAL OF LATVIA UNIVERSITY OF AGRICULTURE

VOLUME 11 NUMBER 11

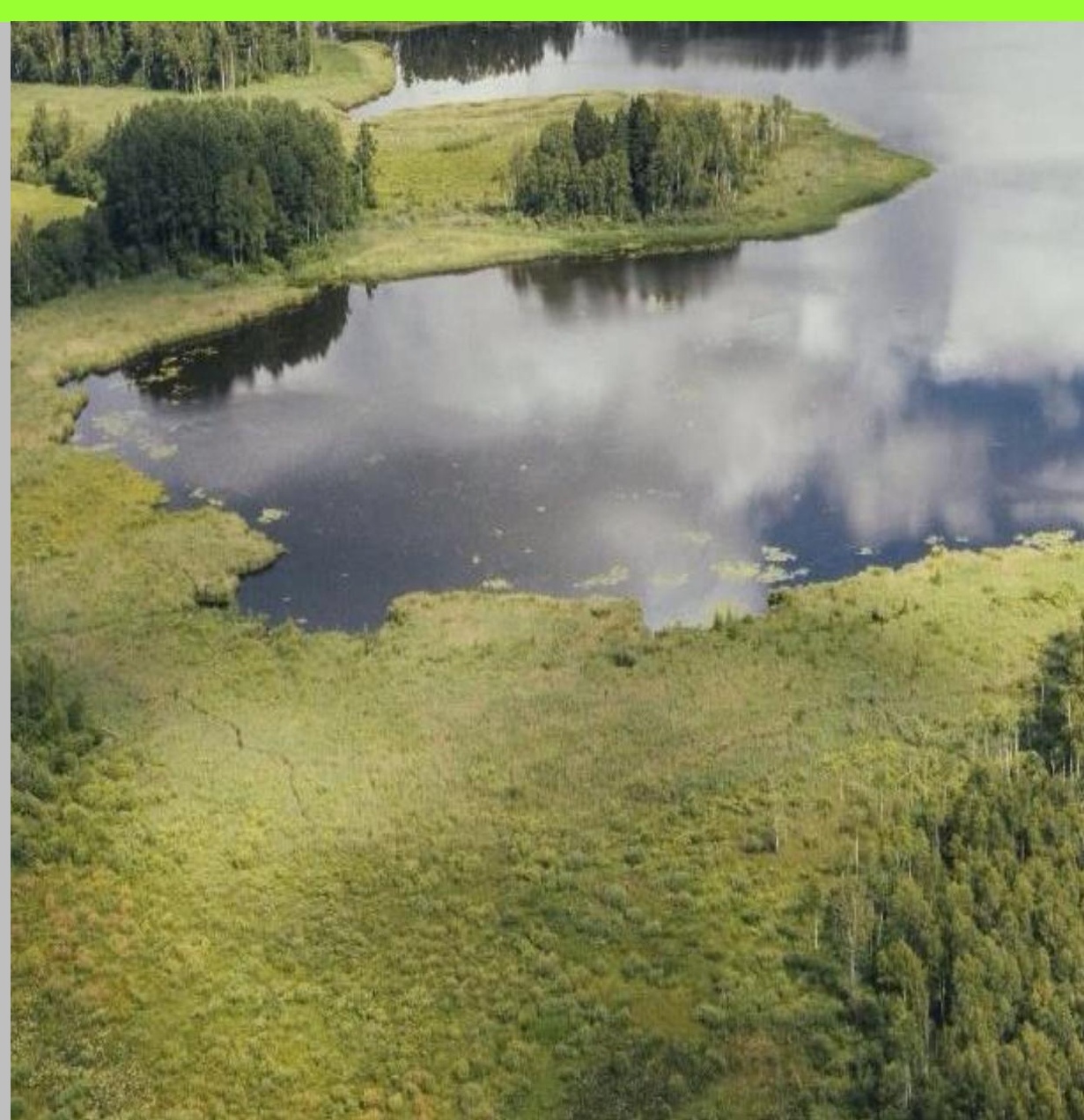


SCIENTIFIC JOURNAL OF

LATVIA UNIVERSITY OF AGRICULTURE

\section{LANDSCAPE ARCHITECTURE AND ART}

VOLUME 11

NUMBER 11 


\title{
EDITOR IN CHIEF
}

Aija Ziemeḷniece, Dr. arch., Professor, Latvia University of Agriculture, Jelgava, Latvia

\section{EDITORIAL BOARD}

Ứgis Bratuškins, Dr. arch., Professor, Riga Technical University, Riga, Latvia Maria Ignatieva, Dr. phil., Professor, Swedish University of Agricultural Sciences, Uppsala, Sweden

Karsten Jorgensen, Dr. scient., Professor, Norwegian University of Life Sciences, Oslo, Norway

Jānis Krastiṇš, Dr. habil. arch., Professor, Riga Technical University, Riga, Latvia Juhan Maiste, Dr. art., Professor, University of Tartu, Tartu, Estonia

Eglė Navickienė, Dr. arch., Assoc. Professor, Vilnius Gediminas Technical University, Vilnius, Lithuania

Thomas Oyen, Professor, Neubrandenburg University of Applied Sciences, Neubrandenburg, Germany

Gintaras Stauskis, Ph.D. arch., Assoc. Professor, Vilnius Gediminas Technical University, Vilnius, Lithuania

Ojārs Spārītis, Dr. habil. art., Professor, Art Academy of Latvia, Riga, Latvia Sandra Treija, Dr. arch., Professor, Riga Technical University, Riga, Latvia Daiga Zigmunde, Dr. arch., Professor, Latvia Univeristy of Agriculture, Jelgava, Latvia

Natalija N,itavska, Dr. arch., Assoc. Professor, Latvia Univeristy of Agriculture, Jelgava, Latvia

\section{SECRETARY AND LAYOUT DESIGNER}

Una Īle, Dr. arch., Latvia University of Agriculture, Jelgava, Latvia

\section{TECHNICAL TEXT EDITOR}

Renāte Čaupale, Ph.D. in Architectural History, Latvia University of Agriculture, Jelgava, Latvia

\author{
ADDRESS OF THE EDITORIAL BOARD \\ Faculty of Environment and Civil Engineering \\ Department of Landscape Architecture and Planning \\ Latvia University of Agriculture \\ 22 Riga street, Valdeka palace, Jelgava, Latvia, LV-3004 \\ Phone: + 37129185575 \\ E-mail: una.ile@1lu.lv
}

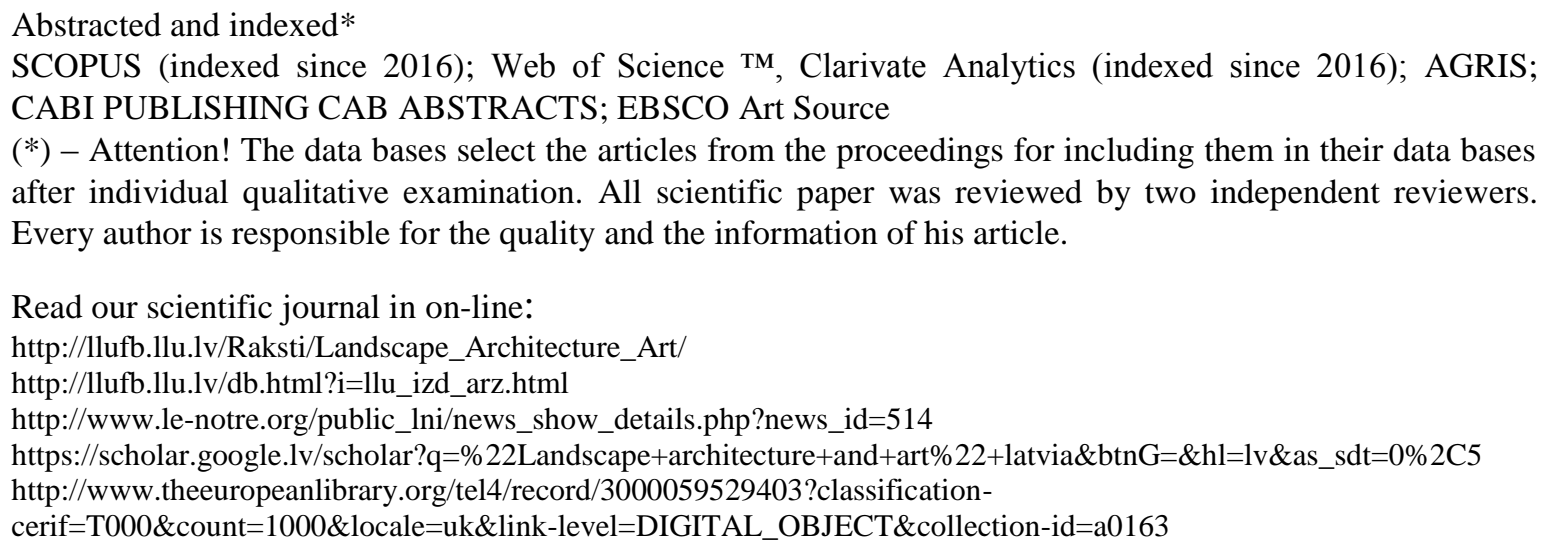

Read our scientific journal in on-line:

http://llufb.llu.lv/Raksti/Landscape_Architecture_Art/

http://llufb.llu.lv/db.html?i=llu_izd_arz.html

http://www.le-notre.org/public_lni/news_show_details.php?news_id=514

https://scholar.google.lv/scholar?q=\%22Landscape+architecture+and+art $\% 22+$ latvia\&btnG=\&hl=lv\&as_sdt=0\%2C5

http://www.theeuropeanlibrary.org/tel4/record/3000059529403?classification-

cerif $=$ T000\& count $=1000 \&$ locale $=$ uk\&link-level=DIGITAL_OBJECT\&collection-id=a0163

Scientific journal cover photo: Mārcis Baltskars

(C) LATVIA UNIVERSITY OF AGRICULTURE, 2017 


\section{INTRODUCTION}

We end up the year with the $11^{\text {th }}$ edition of our journal. It reflects a wide range of studies that examine the cultural and historical values of the manor parks in Latvia from the $18^{\text {th }}$ century up to the time of adjustment of manor ensembles for school needs in the early $20^{\text {th }}$ century. In turn, the contemporary modernist trends in the use of historic parks in large cities create new opportunities for the development of a green recreational space.

The spatial construction of the historic manor ensembles is based on the compositional solution with a clearly readable link to the park, lords' house, driveway, and location of the outhouses. The time of the postwar political attitudes in Latvia against the cultural and historical values has brought very many changes in the compositional structure of the manor ensembles. This applies both to the groups of the new building and tree plantations, excluding the harmony of the historical landscape space. The trends in the preservation of the historic landscape space are attributable not only to the manor ensembles but also to the scale of the city space, which is clearly reflected in the research of Pāvilosta and its industrial zone along the banks of the Saka river. The balance of the existing ecological core and the development of a new urban space are one of the main factors in maintaining the blue-green structure. A similar research on the coastal landscape has been carried out for Engure, by carefully analyzing several criteria and factors affecting the visual aesthetic quality of the populated area. As a common denominator in the above research is a look back at the outdoor and indoor assessment of the context for buildings of a public nature. The publication examines the architectural and landscape values of educational and arts buildings, built in Latvia during the last twenty years, which is appreciated at the national level, giving them the title of the best building of the year.

\section{PRIEKŠVĀRDS}

Gadu noslēdzam ar mūsu žurnāla 11. izdevumu. Tajā atspogulojas plašs pētījumu loks, kas aplūko Latvijas muižu parku kultūrvēsturiskās vērtības no 18. gadsimta līdz pat muižu ansambḷu pielāgošanas laikam skolu vajadzībām 20. gadsimta sākumā. Savukārt, mūsdienu modernisma tendences vēsturisko parku izmantošanai lielpilsētās veido jaunas iespējas zaḷās rekreatīvās telpas attīstībai.

Vēsturisko muižu ansambḷu telpiskās uzbūves pamatā ir to kompozicionālais risinājums, kurā skaidri nolasāma sasaiste parkam, kungu mājai, parādes pagalma, piebraucamā ceḷa un saimniecības ēku novietojumam. Pēckara gadu politiskās attieksmes laiks Latvijā pret kultūrvēsturiskajām vērtībām ir ienesis muižu ansambḷu kompozicionālajā uzbūvē vairākas izmaiņas. Tas ir attiecināms gan uz apbūves raksturu, gan uz koku stādījumu grupām, neievērtējot vēsturiskās ainavtelpas harmoniju. Kultūrvides saglabāšanas tendences ir attiecināmas ne tikai uz muižu ansambliiem, bet arī uz pilsēttelpas mērogu, kas spilgti atspoguḷojas pētījumā par Pāvilostu un tās industriālo zonu gar Sakas upes krastiem. Esošās dabas pamatnes un jaunas urbānās telpas attīstības sabalansētība ir viens no galvenajiem faktoriem zili-zaḷās struktūras saglabāšanā. Līdzīgs pētījums piekrastes ainavtelpai ir veikts par Enguri, rūp̄igi analizējot vairākus kritērijus un to ietekmējošos faktorus, kas iespaido apdzīvotās vietas vizuāli estētisko kvalitāti. Kā kopsaucējs iepriekš minētajiem pētījumiem ir atskats uz ārtelpas un iekštelpas konteksta meklējumiem publiska rakstura ēkām. Rakstā ir aplūkotas pēdējo divdesmit gadu laikā Latvijā uzbūvēto izglītības un mākslas ēku arhitektoniski ainaviskās vērtības, kas atzinīgi novērtētas valsts līmenī, tām piešķirot gada labākās būves nosaukumu.

\author{
Aija Ziemeḷniece \\ Editor in Chief
}




\section{CONTENTS}

Nickolay Vladimirovich Kasyanov

New perspectives for landscape architecture in Russia - Park Zaryadye in Moscow

Aija Grietēna, Aija Ziemelniece, Una Īle

The interactivity of the landscape space and interiors

in the architecture of the Latvian education and art buildings of the $20^{\text {th }} / 21^{\text {st }}$ century

Anna Kalnin,a, Natalija Nitavska

The quality of the public open space in Engure village in Latvia

Dace Ržepicka, Aija Ziemeḷiniece, Una Īle

The industrial heritage around the coast of the Baltic sea at Pāvilosta municipality

Natalija N̦itavska, Artūrs Mengots

Digital Tools in Landscape Architecture

Jānis Zilgalvis

Zasa (Weesen) Manor and Park

Lolita Hercoga, Aija Ziemeļiece

The contextual search in the landscape space of the school and manor building 62 


\title{
New perspectives for landscape architecture in Russia - Park Zaryadye in Moscow
}

\author{
Nickolay Vladimirovich Kasyanov, Scientific Research Institute of Theory of Architecture and \\ Urban Planning (NIITIAG), Moscow, Russia
}

\begin{abstract}
The article considers a recent large-scale landscape-architectural experiment in the historical centre of Moscow. Zaryadye district, mentioned since the XII century, has a rich history, and the most dynamic changes occurred in the XX century, when historical buildings were demolished and several architectural projects of Soviet gigantomania were subsequently tried to realize in this area. By 2010 this territory in the centre of the Moscow turned into a wasteland. By September 2017 a landscape-architectural park was created here according to the project of the American firm Diller Scofidio + Renfro, which won the competition. The park implements an artificial relief, in which a miniature display of different Russian landscapes is integrated with buildings of various cultural purposes. As a result, the sudden transformation of a considerable territory near the Kremlin appeared, and new unexpected and interesting visual landscapes opened. One of the goals is to present a new park to landscape architects and researchers.
\end{abstract}

Keywords: landscape architecture, urban landscape, landscape change, multifunctional park, Moscow, park "Zaryadye"

\section{Introduction}

The work was carried out to explore a new landscape architectural artifact in the centre of Moscow. It should be noted that the work of the Diller Scofidio + Renfro bureau is quite original and innovative, for example, the popular New York High Line park, which was created on the site of the former railway line in Manhattan in 2009 [8]. Park "Zaryadye" (Парк «Зарядье») is the first such large object of urban landscape design in Russia. There are no direct analogs to such a park, but its elements can be compared with some projects of recent years, for example, underground or semiunderground architectural landscape structures, which are quite popular in Europe. So, many buildings can recall works of the architect Peter Vetsch (the Vetsch Architektur bureau), of the architect Friedensreich Regentag Dunkelbunt Hundertwasser or "House of Spiritual Retreat" (Casa de Retiro Espiritual, 2005) [11] of Emilio Ambasch [3], and many others. Trends of sustainable development, ecologization and attempts to humanize the environment on the background of globalization and urbanization are developing, landscape parks integrated into the megacities in different regions from America to South-East Asia are emerging.

Landscape architecture is a dynamic, multidisciplinary field, incorporating architecture, construction, engineering, ecology, garden art and efficiently enhancing the quality of life for the people, protecting the natural environment and saving landscape resources. John Ormsbee Simonds was one of the most influential and well-known

figures in landscape architecture in XX century. He was an environmentalist, professor, and an author of numerous scientific works including the classic "Landscape Architecture" [6], which successfully withstands the test of time, remaining the basic resource for landscape designers. Following books written by M. Laurie, 1975 [5], Alexander et al., 1977 [1], Thompson and Sorvig, 2008 [9] provided data on landscape architecture, environmental design, ecological planning, buildings and construction. Alexander et al., 1977 [1] considered the variety of designs as the realization of a pattern language. Thompson and Sorvig, 2008 [9] argue that the sustainability of ecosystems is a central theme in landscape architecture. J. Steele in his book (1977) [7] interpreted sustainable architecture as the connection between ecological "green" design and sustainable development in countries.

\section{Material and Methods}

The author fulfilled field surveys, photographic fixation, study of different data including printed scientific publications and electronic resources addressing landscape architecture and related topics; descriptive and comparative analysis of the obtained results, using a number of graphic programs and computer tools to create an original schematic map of the park spaces based on cartographic services as well as information materials of the park. The methods used in the construction of the park in Zaryad'e are partially considered in the main text. 


\section{Results and discussions}

This project implemented an attempt to create an islet of nature in the middle of a metropolis, which corresponds to global trends. The very possibility of its appearance allows us to hope for the emergence of other landscape-architectural parks in the urbanized environment.

In the fall of 2017, an unusual landscape architectural park, "Zaryadye" (Парк «Зарядье») was opened in the historical centre of Russian capital. The idea of this object, like its current virtual reality, emerged almost suddenly and was realized relatively quickly. Even at the stage of its project, there was a certain excitement in the society and the media, which reached its apogee after the opening of the park, with positive reviews prevailing in the mass media. This article aims describe the sudden transformation of a considerable territory near the Kremlin and the opening of new visual landscapes in the centre of Moscow.

In Moscow, with its twelve administrative districts, including the new territories, there are about 130 different gardens, parks and squares. "Zaryadye" park is located in the heart of Moscow, near Kremlin; between Varvarka street, Kitay-Gorod, Moskva-river embankment; the nearest metro stations are "Kitay-Gorod" and "Revolution Square". A free entrance from all streets around the park is available each day during 24 hours.

"Zaryadye" is mentioned in written sources from the middle of the XII century [20]. In the 1930s, in Zaryadye it was planned to erect a high-altitude building of the People's Commissariat (Ministry) of heavy industry; many historical buildings and temples were demolished. In 1964, on the foundation of the People's Commissariat the construction of the hotel "Russia" began under the project of D. Chechulin. By the 1990s, the hotel, which had not been modernized for a long time, began to bear losses and was closed in 2006.

Several years ago, a somewhat unexpected for Russia idea of a landscape architectural experiment in Zaryadye emerged. Announced competition for the best concept of the park gathered 87 applications from more than 400 companies from 27 countries. In 2013, the first stage of the competition was held. In the second stage of the competition, six consortiums were selected. The winner of the competition became an international consortium from the Bureau of Diller Scofidio + Renfro, Hargreaves Associates and Citymakers [8]. The studio was founded by Elizabeth Diller and Ricardo Scofidio in 1979. Diller Scofidio + Renfro, based in New York City, is an interdisciplinary design studio that integrates architecture, the visual arts, and the performing arts [2].

The authors of the concept of a new park, assuming the maximum fusion of the urban environment with wildlife, defined it as "wild" or "natural" urbanism. "Our idea is to return the nature to the inhabitants of the city. Every city should have a place where people can relax... Here, people will not be separated from nature...", Elizabeth Diller said. In their concept, architects combined the Kremlin with different types of natural landscapes in Russia, such as the northern tundra, taiga, other forests and meadows, with separate microclimate for everyone [12].

Construction of the park "Zaryadye" began in 2015. To create the park's natural areas, 250 thousand cubic meters of new soil were imported. During the monolithic works more than 100 thousand cubic meters of concrete will be used. The total area of the constructed buildings will be almost 79 thousand square meters. The designed way network has a length of $9 \mathrm{~km}$. Among the priority tasks in the tender documentation was the preservation of the relief with a height difference, as the creation of a system of terraces without tall buildings due to the location next to the UNESCO World Heritage sites - the Moscow Kremlin and Red Square [21]. An important element of the project is that routes are not prescribed, and visitors will be able to navigate the park as desired.

The timing of the delivery of such complex and large-scale facility was quite tough. The park was built in 2,5 years; more than five thousand people worked here all day and night. During this time, near the Kremlin walls forests and meadows, a "Glass Crust" and other constructions emerged, mostly locating underground (Fig. 1). The park was inaugurated on September 9, 2017 on the City Day, the 870th anniversary of Moscow. During the first week more than 250 thousand citizens visited "Zaryadye". On weekdays, the park was visited by 10-30 thousand people. Expected, that the park "Zaryadye" will be visited by 10-12 million people a year [17].

The recreation zone emerged near the very walls of the Kremlin. "Zaryadye" park is a miniature display of Russia's landscapes. The total area of the park is more than 13 hectares, the park itself occupies an area of 10.2 hectares. The total area of the objects is more than 80 thousand square meters [18]. The park represents the main landscape and climatic zones of Russia: the northern tundra, coniferous and mixed forests, birch groves, coastal forest (Fig. 2), meadows, mini-lakes (Fig. 3) with aquatic plants. Landscapes are terraces, 


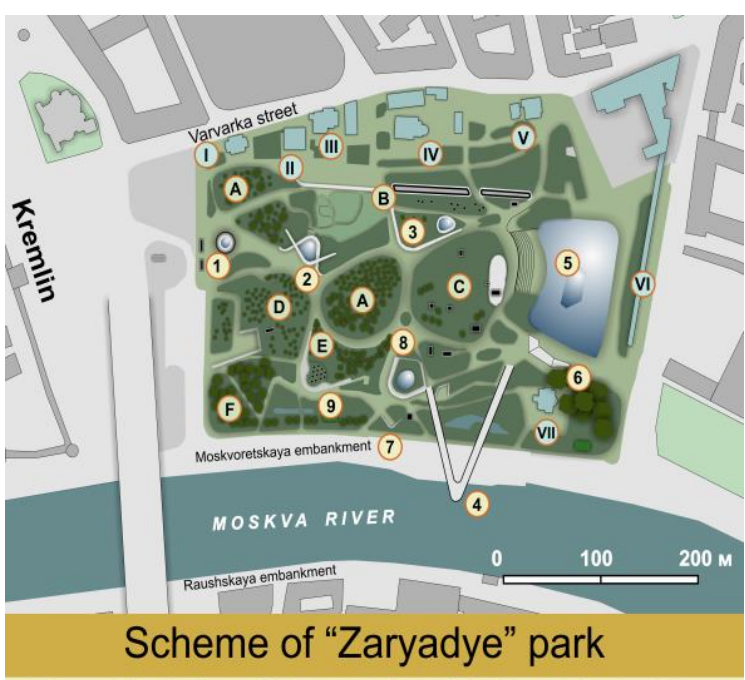

1. Dome; 2. Media Center; 3. Reserve Ambassy \& Ice Cave; 4. Soaring Bridge; 5. Glass Crust, Big Amphitheater \& Concert Hall; 6. Small Amphitheater; 7. Underground Museum; 8. Café; 9 . Restaurant

A. Birch Forest; B. Nothern Landscapes; C. Meadow; D. Mixed Forest; E. Coniferous Forest; F. Coastal Forest

I. Church of Great Martyr Barbara in Varvarka; II. Old English Court Museum; III. Saint Maximus's church; IV. Cathedral of Znamensky Monastery; V. Church of Saint George the Victorious; VI. Fragment of the Kitay-gorod wall; VII. Church of the Conception of St Anne

Fig. 1. Schematic plan of the "Zaryadye" park [created by the author]

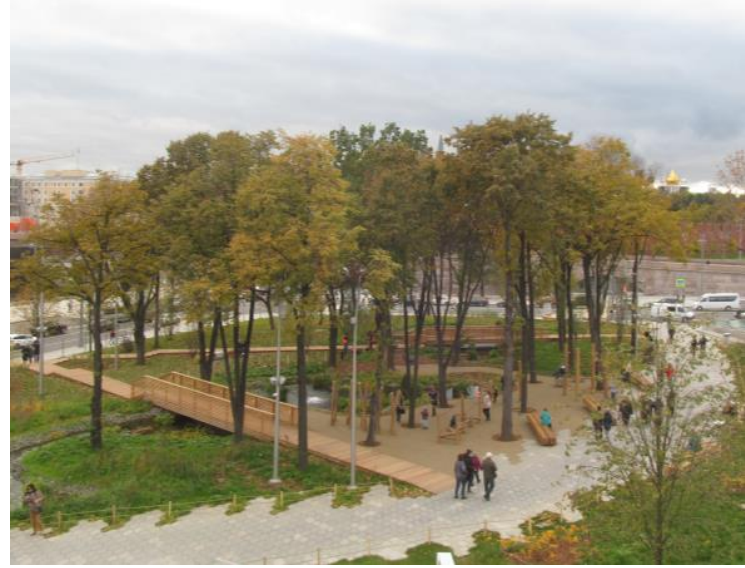

Fig. 2. View of the "coastal forest" [photo by the author]

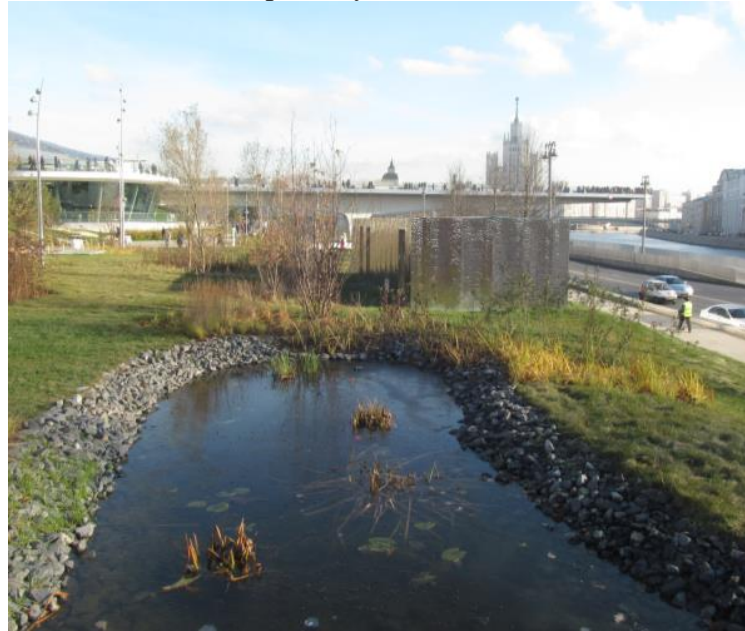

Fig. 3. One of the ponds [photo by the author]

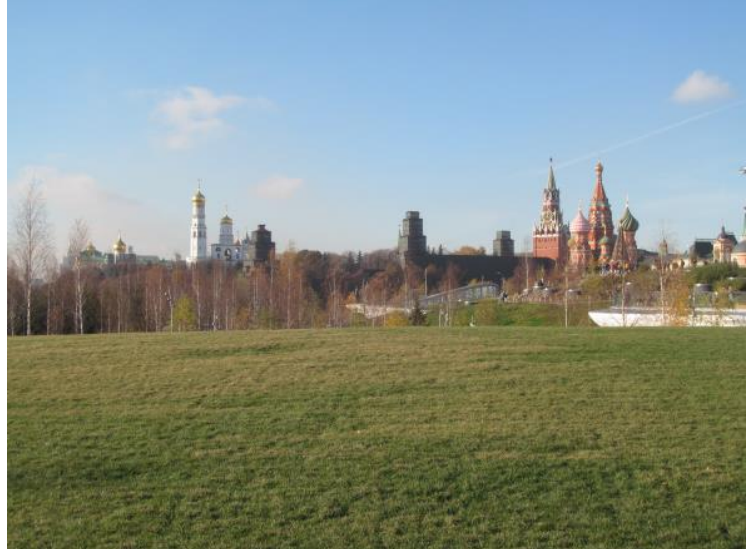

Fig. 4. Unusual panorama of the city centre [photo by the author]

successively descending from the upper level of the site to its lower part (from the north-east to southwest), intersecting and overlapping. Approximately 750 trees, 7000 shrubs, more than 850 thousand perennial flowers, about 150 thousand annual flowers are planted here. In the "Zaryadye" park there were about 120 species of native plants, even plants from the Red Book of Moscow. An additional planting out of 450 thousand plants is planned. In addition, a separate zone of ponds (in place of the former bed of the Neglinka River) has been constructed [17]. Young willows, irises and forget-me-nots were planted along the banks; snow-white water-lilies and reeds appeared in the reservoirs. For the convenience of the visitors of the park, wooden bridges are thrown across the ponds.

Thus, in Zaryadye an artificial relief with unique landscapes, lowlands and hills formed, from which new, unexpected picturesque views are opened. From the tops of the hills you can see the Kremlin, Red Square, St. Basil's Cathedral and the high-rise building on Kotelnicheskaya embankment, as well as the monuments of Zaryadye itself, restored during the creation of the park. In addition, the "Glass Crust" with large amphitheater is best seen from here, from the park it looks like a glass-covered mountain with the amphitheater on a slope. New visual panoramas are opened because buildings in the park mostly are hidden under the landscape (Fig. 4). In essence, the park exploits roofs of buildings [14]. At the same time, "Zaryadye" is a cultural and educational centre with complicated architectural objects, a fairy town with houses-hills, each of which is a multifunctional pavilion. It is simultaneously a park, a city square, and a cultural landmark.

Sometimes a similarity between "Zaryadye" and High Line Park in Manhattan in New York and European parks was found, but the uniqueness of the "Zaryadya" landscape is in its botanical collection, represented by plants from different parts of Russia. Such a variety of plants, revealing the country's natural diversity, is nowhere else. At the same time 
it is a territory of silence, tranquility, recreation [14]. It is necessary more comprehensive description of main architectural objects of the park. Near the entrance to the park "Zaryadye" from the side of Vasilievsky descent there is an information pavilion "Dome". The pavilion is equipped with a set of QRcodes (on walls and ceiling); activating QR-codes with a smartphone or tablet, you can get information about the territory and objects of "Zaryadye" park. The "Dome" is an allusion of Russian Pavilion at the Venice, received a prize at the Venice Architectural Biennale in 2012 [4]. The pavilion symbolized the innovative centre Skolkovo, a modern scientific and technological complex, the first science city built in the post-Soviet Russia.

In the multifunctional interactive complex "Media Center" (Fig. 5) there are also 14 small service places around the park where you can buy or order tickets for exhibitions or master classes.

The white colouring of the outer walls of the pavilions, "half-buried" in the ground, emphasizes the plasticity of concrete "casting"; in sunlight an interesting play of light appears.

In the "Media Center", you can show threedimensional films accompanied by additional "presence effects". The "Flight over Russia" attraction using a huge parabolic screen and chairs on a mobile platform, creates the illusion of soaring above the earth surface; multichannel sound and special effects in the form of water spray, wind generators, smoke and smells simulate the geyser sprays, wind flow, volcanic heat and smoke, smells. Before the eyes of spectators, the active volcano in Kamchatka, fantastic stone columns in Komi appear. Another attraction film, "The Time Machine Zaryadye", using the panoramic screen with a projection of 360 degrees and 5 meters high as "Time Machine", transfer you to the tenth century when the tribe of Vyatichi lived on the banks of the Moscow and Neglinnaya rivers, surrounded by impenetrable forests [17].

The educational centre "Reserve Ambassy" (Fig. 6) includes a scientific centre with lecture halls for lectures and experiments, classes in genetics, biotechnology, microbiology, geography and ecology. During the construction of the underground passage, some disassembled stones of the ancient wall of the Kitay-gorod were moved to the "Reserve Ambassy" for finishing the main entrance wall [14].

In the hall of "Media Center" there is a florarium (Fig. 7) - a hothouse complex under a glass roof for growing more than 500 species of tropical plants using hydroponics, that is, without soil, on the basis of a complex engineering system for preparing nutrient solutions and feeding the root system of plants [16].

On the area of the "Reserve Ambassy", which is 3,300 square meters, there is also the "Ice Cave"

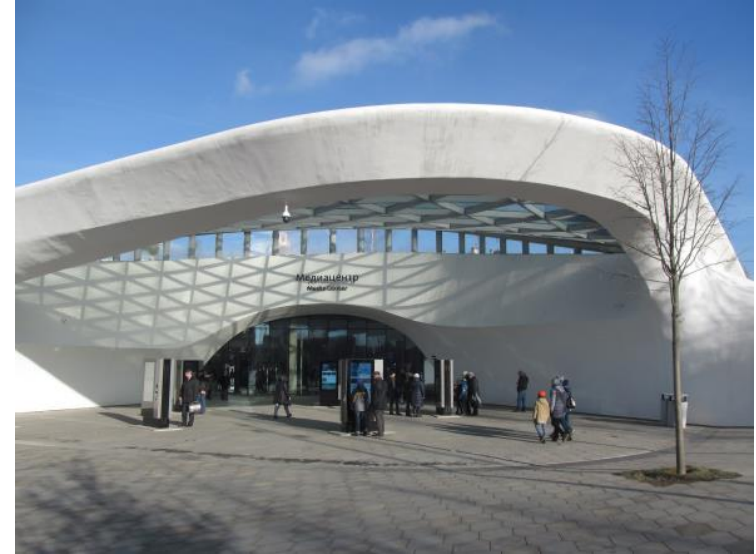

Fig. 5. The entrance in the "Media Center" [photo by the author]

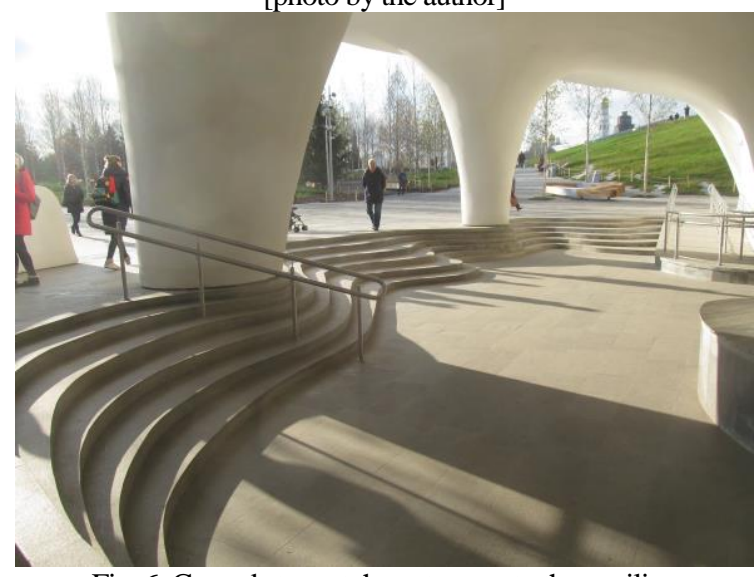

Fig. 6. Curved steps at the entrances to the pavilion "Reserve Ambassy" [photo by the author]

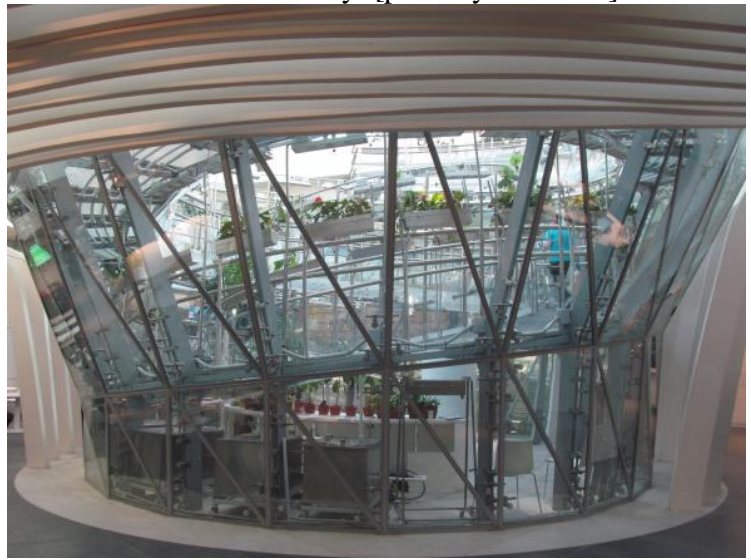

Fig. 7. "Florarium" in the "Reserve Ambassy" [photo by the author]

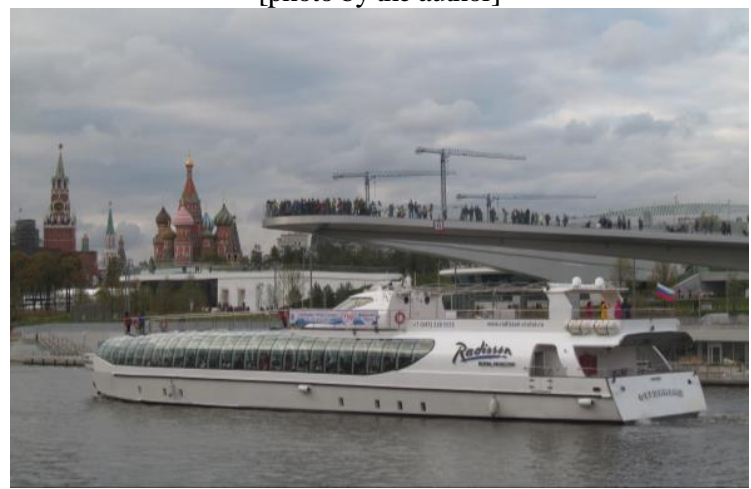

Fig. 8. A view of the "Soaring Bridge" from the Raushskaya embankment [photo by the author] 

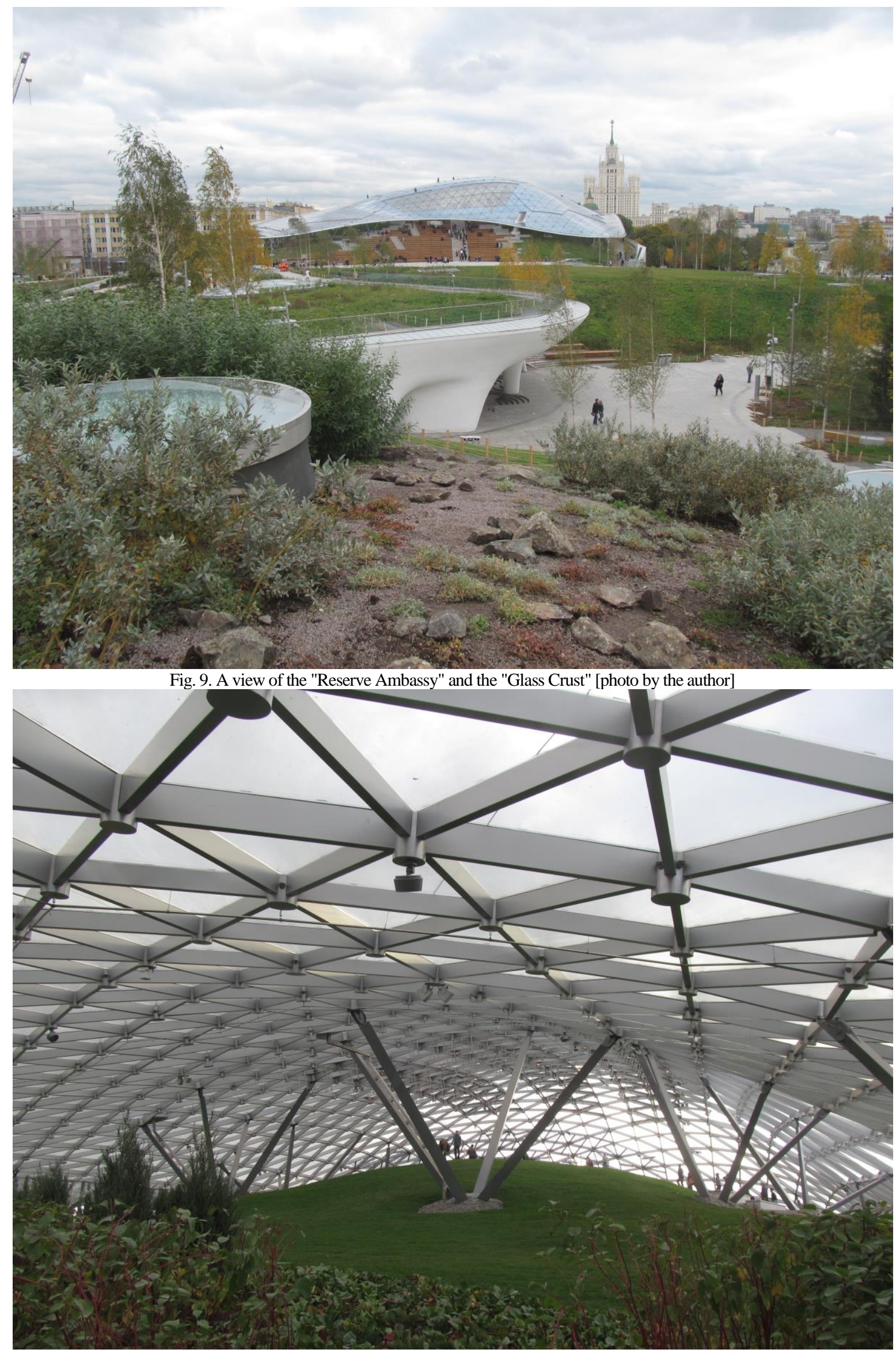

Fig. 10. "Glass Crust" from the inside [photo by the author] 


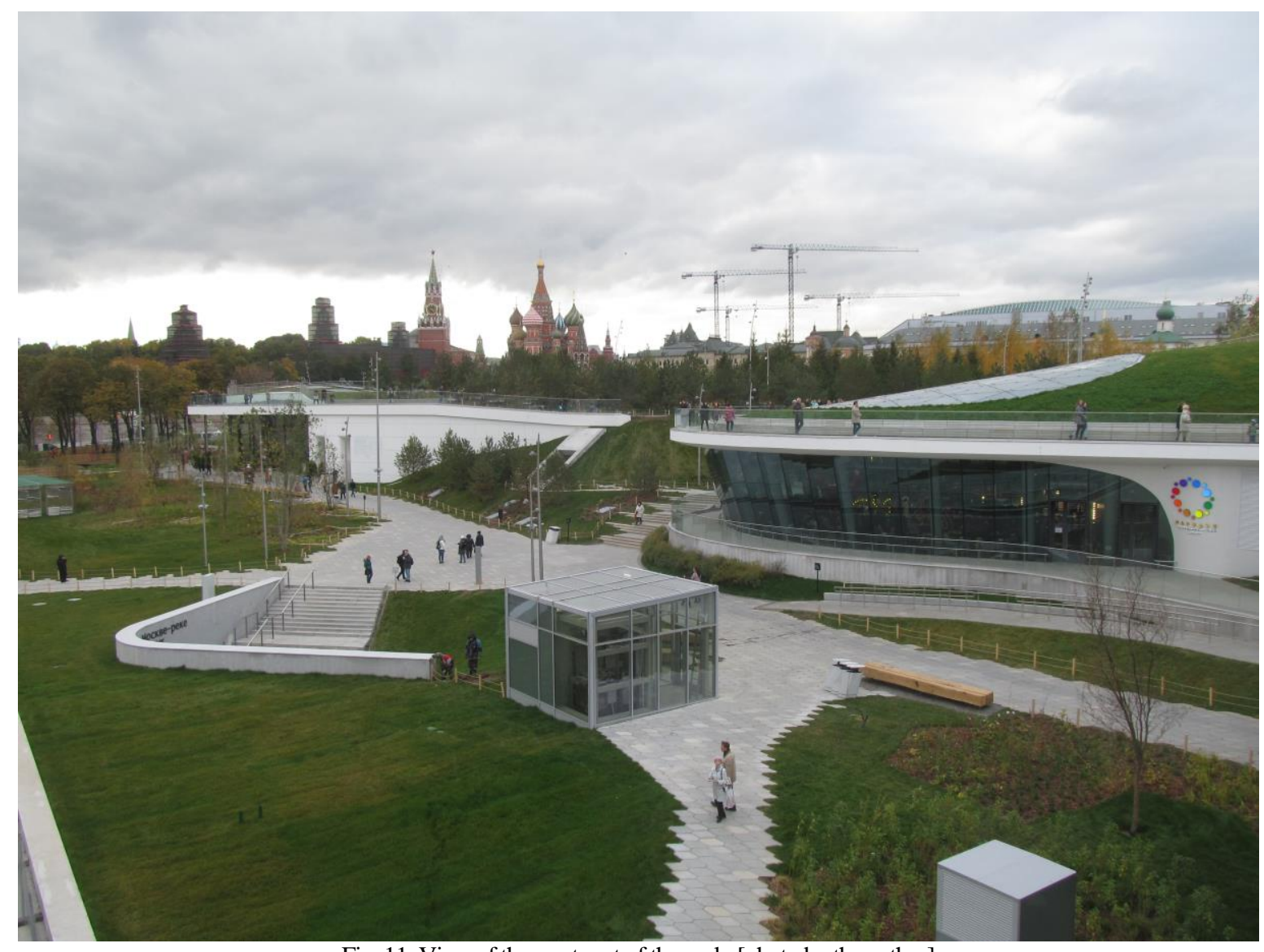

Fig. 11. View of the west part of the park [photo by the author]

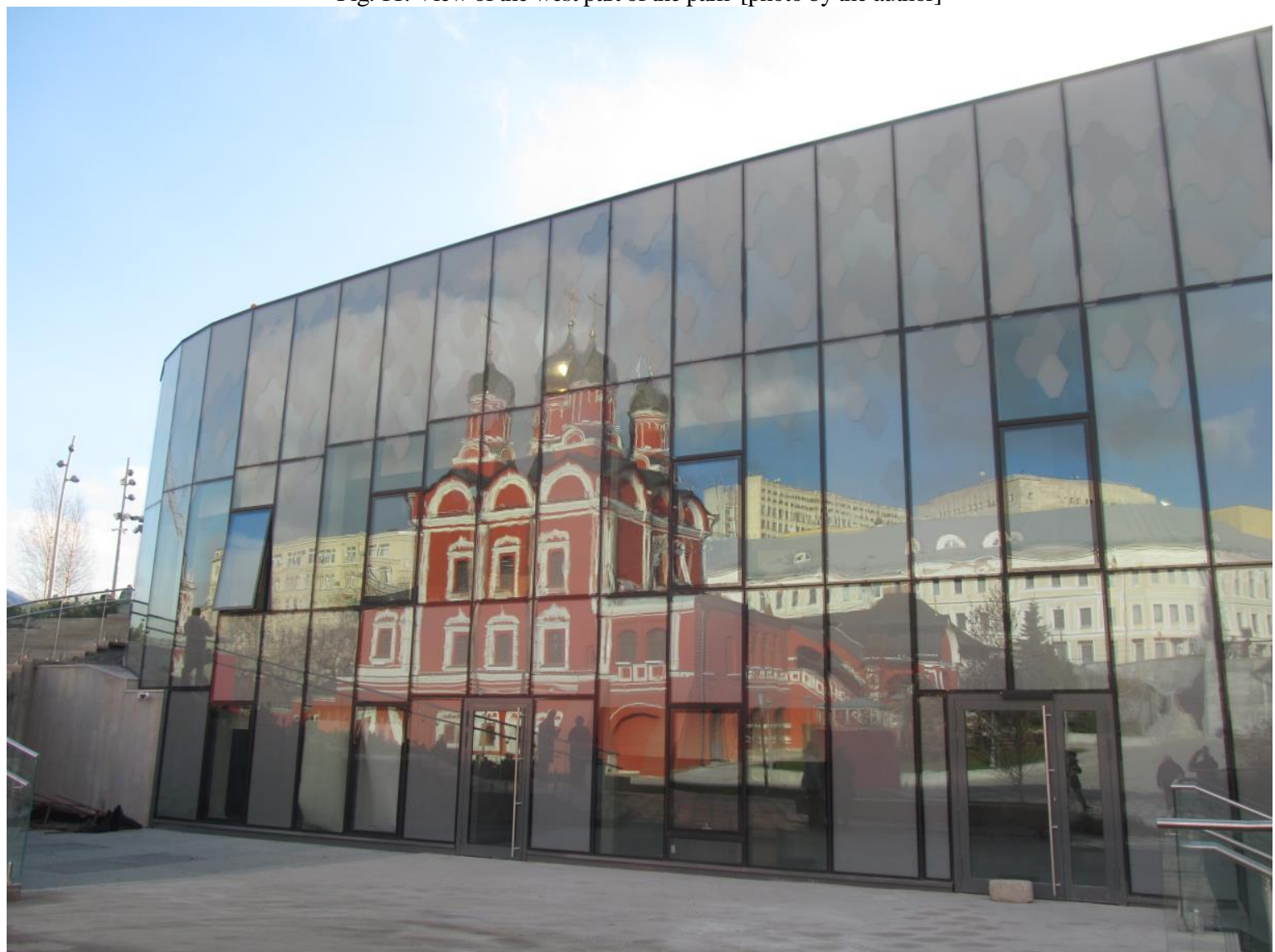

Fig. 12. Reflections of the Znamensky Cathedral in the glass facade constructions of the park [photo by the author] 
with a temperature $-5^{\circ} \mathrm{C}$ inside it. For the formation of the ice, 70 tons of water and a week for its freezing were required. The cave framework is made of seven layers of fiber-reinforced concrete, which includes a large number of fine elastic fibers that reinforce the entire layer, as well as chemical additives to increase plasticity. The northern flora and fauna will be shown with the help of video projections and voice-over text. For one hour, 130 people which in the warm season will receive special mantles, can visit the glacier to inspect the exposition [17].

One of the main attractions in "Zaryadye" is a unique "Soaring Bridge" (Fig. 8), pedestrian overpass in the form of the letter "V" with a 70-meter console without a single support. The bridge supports are installed in the park, and the console with a viewing platform hangs over the Moskva-river at an altitude of about 14 meters. Thus, the effect of soaring over the river is created.

At the same time, 3-4 thousand people can be on the bridge; the structure can withstand a weight of more than 240 tons. The weight of the bridge itself is 3,700 tons. The total length of the bridge is 244,4 meters; The length of the outboard console without supports is 69 meters [16]. The bridge consists of two reinforced concrete beams. In addition to concrete, metal structures and glass are actively used. The bearing structure of the bridge is made of concrete, from below and on the sides "Soaring Bridge" is lined with stainless steel, and the flooring is wooden.

The most large-scale construction of "Zaryadye", one of its dominants is the "Glass Crust" (Fig. 9) a curvilinear spatial covering formed by glass triangles enclosed in a metal frame. With its glass facade, the building is facing towards Kitay-Gorod, and behind it gradually passes into a hill on the slope of which is a big amphitheater. The amphitheater covered with the "Glass crust" is the highest point of the park. Wood-metal frame of glass triangles (Fig. 10) covers about a hectare of territory. This is the world's largest translucent structure without enclosing walls, which protects visitors from the rain and wind. The use of energy-saving technologies allows maintaining a higher temperature than in the open air, even in winter: 150 solar batteries are installed in the southern part of the "Glass crust". The photocells are integrated into the triplex of the double-glazed windows, which fill the cells of the cover; at the same time, the photocells do not occupy the whole area of the glass unit and retain the transparency effect of the "Glass crust", under which one of the main sites of the park is located. The only wall covering the structure is located on the east side, where the "Glass Crust" adjoins the concert hall. Inside, the engineering systems for supplying warm air in winter are installed, as well as for cooling and humidifying the air in summer heat. To operate the structure in winter, there is a system of snow melting and a safety system for climbers who will clean the roof of the snow. Year-round green plants will be under the "Glass crust".

Under the "Glass crust" two transformable halls: a large (for 1560 people) and small (for 400 people), as well as a studio for sound recording, are disposed [17]. The concert platform will be multifunctional. It will sound not only symphonic music, but also variety and jazz concerts. Philharmonic is a closed room with transformable parterre, stage, orchestra pit of the main concert hall.

The underground museum "Zaryadye" has interactive show-windows. In the transition from the park to the embankment one can see a fragment of the Kitay-Gorod wall of the XVI century, customs seals and coin treasures, in the glass window - fragments of the pavement of the ancient Moscow street, Velikaya, at the stands - ancient weapons and horse equipment [13]. There is also a gastronomic centre "Zaryadye", which includes cafes and restaurants (Fig. 11).

Lanterns designed unusual, for illumination of landscape zones, 460 lamps were installed. In the busiest parts of the park, the main light sources are 140 lanterns with a height of 6 to $13 \mathrm{~m}$. The brightness and colour of the lighting in all park lights can be changed depending on the time of day and weather, for example, during rain and fog, the lanterns are brighter [18]. In the grass cover of the park, numerous light windows have been made, illuminating the underground rooms. Underground parking is designed for more than 400 cars. Facades of some buildings are covered with wavy mirror material (Fig. 12), giving them a low-key and somewhat ephemeral look.

The park is surrounded by historical temples and gardens, including the "Old English Court" Museum. It should be noted that the panorama of the historical Varvarka street, in which many historical objects were preserved, became interestingly opened. Along the Varvarka, old churches have been restored: the cathedral, bell tower and buildings of Znamensky Monastery (XVII century), the churches of Great Martyr Varvara (XVIII century), Saint Maximus the Blessed (XVII century), Saint George the Victorious (XVII century), Conception of Saint Anne (XVI century) [15]. Nearby are the chambers of the boyar family Romanovs, as well as remnants of the Kitay-Gorod wall. 


\section{Conclusions}

"Zaryadye" park is the first large-scale object of urban landscape design in Russia. With the opening of "Zaryadye", discussions between supporters and opponents of the project broke out with a new force, remaining opponents in the minority.

Concern for the health of outdoor places is a central theme in landscape architecture integrating natural and manmade worlds. Generally, the task of humanizing the local space has been solved using contemporary tools. This large-scale project integrated various modern trends directed towards the development of sustainable and ecological landscape architecture.

In general, the project is implemented at a sufficiently high level. An unexpected and interesting architectural landscape experiment was obtained. Undoubtedly, in Russia the first most serious attempt was made to create a landscape architectural object of world level.

\section{References}

1. Alexander C.W., Ishikawa S., Silverstein M., Jacobson M., Fiksdahl-King I., Angel S. A Pattern Language: Towns, Buildings, Construction. Oxford University Press, USA. 1977. 1171 pp. ISBN 978-0-19501-919-9

2. Diller Scofidio + Renfro index [online 30.10.2017] https://dsrny.com/

3. Casa de retiro espiritual [online 31.01.2018] http://casaderetiroespiritual.com/index.php

4. Etherington R. Russian Pavilion at the Venice Architecture Biennale 2012 [online 30.10.2017] https://www.dezeen. com/2012/08/29/russian-pavilion-at-venice-architeture-biennale-2012/

5. Laurie M. An Introduction to Landscape Architecture. American Elsevier Publishing Company, Inc., 1975. 214 pp. ISBN13: 978-0-44400-171-9

6. Simonds J.O. Landscape Architecture: The Shaping of Man's Natural Environment. McGraw-Hill Book Company, Inc. 1961. 244 pp.

7. Steele J. Sustainable Architecture: Principles, Paradigms and Case Studies. New York: McGraw-Hill. 1997. 288 pp. ISBN 978-0-07060-949-7

8. The High Line all phases [online 30.10.2017] https://dsrny.com/project/high-line

9. Thompson W., Sorvig K. Sustainable Landscape Construction. A Guide to Green Building Outdoors. Second Edition. Island Press: Washington, Covelo, London. 2008. 412 pp. ISBN 978-1-59726-142-5

10. Ulam A. In Putin's Moscow, an Urban Wilderness Emerges [online 30.10.2017] https://www.citylab.com/design/ 2017/05/in-putins-moscow-an-urban-wilderness-emerges/526872/

11. Vetsch Architektur vetsch architektur [online 31.01.2018] http://www.erdhaus.ch/

12. Zaryadye Park [online 30.10.2017] https://dsrny.com/project/zaryadye-park

13. Бычкова Е. Где укрылось племя вятичей? В «Зарядье» можно погрузиться в глубину веков [online 30.10.2017] http://www.aif.ru/realty/city/gde_ukrylos_plemya_vyatichey_v_zaryade_mozhno_pogruzitsya_v_glubinu_vekov

14. Волкова С. «Зарядье» - это страна в миниатюре [online 30.10.2017] https://stroi.mos.ru/articles/zariad-ie-etostrana-v-miniatiurie

15. Волкова С. Парк «Зарядье» в Москве: 5 особенностей парка, ради которых в нем стоит побывать [online 30.10.2017] https://www.msk.kp.ru/daily/26729.5/3755819/

16. Завершнева О. Строители рассказали, как возводили парк «Зарядье» [online 30.10.2017] https://stroi.mos. ru/articles/glazami-stroitieliei-kak-sozdavali-park-zariad-ie

17. Зарядье: парк настоящего будущего [online 30.10.2017] http://www.zaryadyepark.ru/

18. Никитская Е. «Зарядье»: настоящий парк будущего [online 30.10.2017] http://www.mk.ru/moscow/ 2017/09/13/zaryade-nastoyashhiy-park-budushhego.html

19. Парк «Зарядье» - новый символ Москвы [online 30.10.2017] http://www.zaryadyepark.ru/smi/park-zaryadenovyy-simvol-moskvy/ здесь много всего

20. Сытин П. В. Из истории московских улии. Москва: Московский рабочий, 1958, с. 67.

21. Уриханян А. С южных гор до северных морей [online 30.10.2017] http://portal-kultura.ru/articles/moskva/ 140223-s-yuzhnykh-gor-do-severnykh-morey/

\section{INFORMATION ABOUT AUTHOR:}

Kasyanov Nickolay Vladimirovich. Born in 1973, Leningrad. Educational background: 1993-1999 Architectural Institute of the Far Eastern State Technical University (Arch IDVGTU), now part of the Far Eastern Federal University), diploma with honors. 1999-2002 the postgraduate program. Since 2004 a candidate of architecture. Employment: 1999-2004 the teaching staff, Arch DVGTU, Vladivostok. Since 2004 - Senior Research Fellow, Scientific Research Institute of Theory of Architecture and Urban Planning (NIITIAG), Moscow. Since 2006 - Head of Lab of Architectural Form Creation, NIITIAG. The author of more than 60 published works, with experience of design works. Scientific interests: form creation in architecture and nature, innovative technologies in architecture, fortress architecture. 111024 Moscow, Dushinskaya str., 9, tel/fax +7 (499) 95182 72, phone 891513879 72. E-mail: kas_nv@mail.ru

Kopsavilkums. Rakstā tiek aplūkota parka Zarjadje (Парк «Зарядье») teritorija, kas ir kā viens no pēdējiem liela mēroga ainavu arhitektūras projektiem Maskavas vēsturiskajā centrā. Parks veidots kā inovatīvs piemērs, kas ietver mūsdien̄̄gus risinājumus un ir kā izziņas teritorija gan ainavu arhitektiem, gan pētniekiem. 


\title{
The interactivity of the landscape space and interiors in the architecture of the Latvian education and art buildings of the $20^{\text {th }} / 21^{\text {st }}$ century
}

\author{
Aija Grietēna, Aija Ziemeḷniece, Una Īle, Latvia University of Agriculture
}

\begin{abstract}
The article summarizes a small part of the research material, which considers the context search of the landscape space, architecture, and the indoor space in the architecture of education and art buildings. The schools and art buildings built at the turn of the 20th/21st century awarded with the Prize of the Year at the Latvian Architecture Best Works Award are used in the research. The context of the language of architecture and landscape space is formed by the knowledge of interdisciplinary directions of science that essentially affect the ecological, visual, visually aesthetic, and economic indicators. Studying more closely at this, this is also true of the aesthetic-psychological interactions among landscape architecture, architecture, and interior design, which are achieved in building sites with widespread glazed facades. Thanks to today's highly advanced construction technology capabilities, the visual transparency and illusory ease of buildings are increasingly able to create visual interconnections among the landscape space, architectural form creation, and interior.
\end{abstract}

Key words: indoor/outdoor harmony, landscape architecture, architecture, interior, glass systems.

\section{Introduction}

At the Latvian level, as well as at the global one, environmentalists, in their practices experience an increasing need for interdisciplinary co-operative planning, and we all, as environmental users, in our routinely day-to-day activities are pursuing the integrity and harmony of the environment [1-4; 6-19]. It is supported by the growing use of transparent, wide exterior glazed planes in architecture, which with a new, illusory, and plastic architectural form creation is clearly evident in the modern architecture of Latvian education and art buildings at the turn of the $20^{\text {th }} / 21^{\text {st }}$ century. This tendency is also evidenced by the results of the annual major architectural and construction competitions in Latvia for the last 25 years [12].

The modern education and art buildings in the contemporary Latvian landscape are characterized by higher multifunctionality and transformability than they had before. The new technological possibilities promote a wider creativeness of the environment makers, creating a higher degree of synthesis of architecture with landscape architecture, interiors, design, and other creative disciplines. By combining the visual interconnections among the landscape architecture, form creation of building volumes, and the indoor space, there are more opportunities and freedom to form creation. Therefore, today the environment makers and users are in front of the opportunity and responsibility by visually linking the landscape space with the indoor space through widely glazed translucent planes in architecture.
With the increase of the general level of education in aesthetics, ethics, and ecology of Latvia's society, nowadays it is increasingly involved in various environmental development processes through public comments. Due to the social sensitivity of sites and their widespread public character, the aspect of the integrity of architecture, the interior, and landscape of the educational and artistic buildings is often sparked by a wide public resonance. In order to create the integrity and harmony of the environment, opening the indoor space to a mutually qualitative interaction with the landscape requires an appropriate theoretical basis, which is manifested through scientifically sound mechanisms for the adjustment of urban environmental processes. Currently, the theoretical basis consists of a set of separate aspects $[4 ; 10]$.

Professor I. Strautmanis wrote about the lack of the environmental quality in Latvia in his publications in the last century, reflecting the results of research carried out [9]. But today 'the technical possibilities of the architects' creative work have changed, the range of materials and technological equipment has expanded but the quality of the environment is improving slowly. Due to the restoration of the private land ownership, harmonious planning of the urban environment is very difficult. The desire of entrepreneurs and investors to obtain the most favorable place in the city at all costs and to earn money with architecture also often improves not only the overall visual image of the environment, but, on the contrary, generates regular "shoe box" displays along the city's important highways. Architecture is 
increasingly losing its stagnant quality over the course of the century, becoming more and more illuminated and dummy. Today, the informational and emotional potential of architecture is a completely unattractive and undervalued quality. An in-depth research is needed to create a common platform for a dialogue between architects and designers in the light of the recent scientific discoveries [10].

The aim of the research is to determine the factors contributing to the psycho-emotional quality of the landscape space and interiors in the art of building the environment in the architecture of the Latvian education and art buildings that arose at the turn of the $20^{\text {th }} / 21^{\text {st }}$ century, studying the experts' highly rated three concert halls, two libraries, and eight educational buildings.

\section{Two tasks are ancillary to the aim:}

- to evaluate the interaction of the landscape space and the indoor space in the context of the socially sensitive typology of the public education and art buildings in the architecture of Latvia, created at the turn of the $20^{\text {th }} / 21^{\text {st }}$ century;

- to formulate harmonious interaction factors of landscape space and interiors in the art of building the environment of architecture of the Latvian educational and art buildings, in their typological context.

The theoretical and practical significance of the work is the formation of psycho-emotionally more harmonious and high-quality spatial environment in Latvia, through better cooperation between architects, landscape architects, and interior design specialists.

In practice, andscape architects, successfully cooperating with architects, interior designers, and designers, have been able to create a number of artistically high-value environmental sites that are characterized by the integrity or wholeness of the environment, thus fragmentarily improving the quality of our urban landscape space. In cooperation with Latvian and international experts, three concert halls, two libraries, eight educational buildings have been especially appreciated in this regard, analyzing of which, knowledge is obtained that in the future could be used in the art of creation of the environment, as well as in the interdisciplinary cooperation to create a high-quality environment.

\section{Materials and Methods}

The subject of the research is the interaction of landscape space and interiors in the architecture of Latvian education and art buildings at the turn of the $20^{\text {th }} / 21^{\text {st }}$ century, passing through wide glazed, transparent outer planes of the building volumes within the visual linking boundary (Fig. 1).

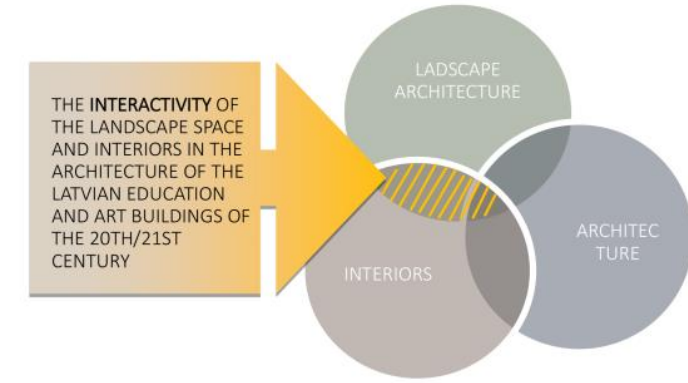

Fig. 1. The visual-aesthetic and psychological interaction of the landscape space and interiors [created by the authors, 2016]

\section{Research methods:}

The empirical and comparative analysis - for surveys of educational and art buildings in nature (for photo-fixing, analysis of interaction factors according to common criteria), interview collection and analysis, clarifying the opinions of experts, specialists in the sector of the society, spatial planning, and architecture, as well as social respondents about the interaction between the outdoor space and the indoor space in the context of typology of the education and art buildings in the architecture of Latvia, which dates back to the turn of the $20^{\text {th }} / 21^{\text {st }}$ century.

The graphically comparative and inductive cognition method, determining the factors contributing to the psycho-emotional quality of the landscape space and the indoor space interactions in the art of building the environment in the architecture of the Latvian education and art buildings.

\section{The application of the comparative method in} summarizing information for the research:

1. Principles of the glass system application in architecture:

- Composition of glass panel areas in space and their proportion - massiveness in relation to parts without glass.

- Compositional application of colors and chiaroscuro under the insulation impact.

- Research of visual accents created by the chiaroscuro play.

- Assessment of the semantic correspondence of indoors/outdoors and level of emotionality according to the functional program of the respective space.

2. Summary of studies on the impact of the mutual compositional build of indoors/outdoors:

- Architectural shape-building, glass systems, and the landscape around sites as the main criteria in the search for harmony between indoors and outdoors, compliance with the supreme spiritual task following the function of spaces.

- Assessment of the indoor/outdoor harmonysummary of opinions of experts and other respondents on correspondence of the 
indoor/outdoor dialogue to the supreme task of a site under consideration.

In the analytical generalization phase, the priority factors of the outdoors/indoors harmony were determined by virtue of the inductive cognitive method.

\section{Results and Discussion}

The research covers the best (winning) architectural sites of Latvia in the typological context of the educational and art buildings but in reality, there are many times more harmonious, remarkable sites in Latvia, so narrowing the boundaries (Table 1) has been set in order to preserve consistency in the quantity and quality of the selection of sites. The site research uses the matrix described in the introduction, which includes both an analytically descriptive situation analysis and a psycho-emotional quality assessment of interactions.

As the first of the criteria, the use of glazed area compositions and proportions in relation to the nonglazed parts in the interior were analyzed. An excellent example of the proportionality of glazing, with the integration of the urban landscape into the ballet hall and the lobby, wide stairs along the outer glazed inner wall of the southeastern facade raise the visitor's sight points at several levels above the city's roofs (architect Volker Giencke) is the interior of the Concert Hall "Lielais Dzintars" with a cylindrical glazed shape. Also, the University of Latvia's Academic Training Center for Natural Sciences in Tornakalns, the vertical extension of the glazing of which is extended in a parallelpiped form brings in balance with the nearby landscape space. The silhouette of the National Library of Latvia, designed by the architect Gunārs Birkerts, reminds of the spiritual literary riches. It should be noted that the proportion of the library's glazing in relation to the non-glazed part leaves a bright and light presence of the landscape space in the interior. The presence of the river Daugava and the silhouette of Old Riga is easily and unobtrusively apparent in the reading rooms on all the floors. In turn, the part of the southern facade glazing is raised so as to ensure insulation of the rooms. An essential role in the sphere of space formation art is the game of the entire light, which enters the building volume from the peak of the illusory hill. The Pārventa library in Ventspils has a compositionally powerful solution with a rounded, triangular cylindrical game of shapes, which is integrated into the residential building. The glass facades in the reading rooms and lobby link the indoor with the street plantings. As a vivid example, the new annex of the Academy of Arts, in contrast to the glazed planes, the rough concrete forms of the inclined parallelepiped, which are in contrast with the glazed planes and indirectly
TABLE 1

The study sites in the typological context with the placement in nature [created by the authors, 2017]

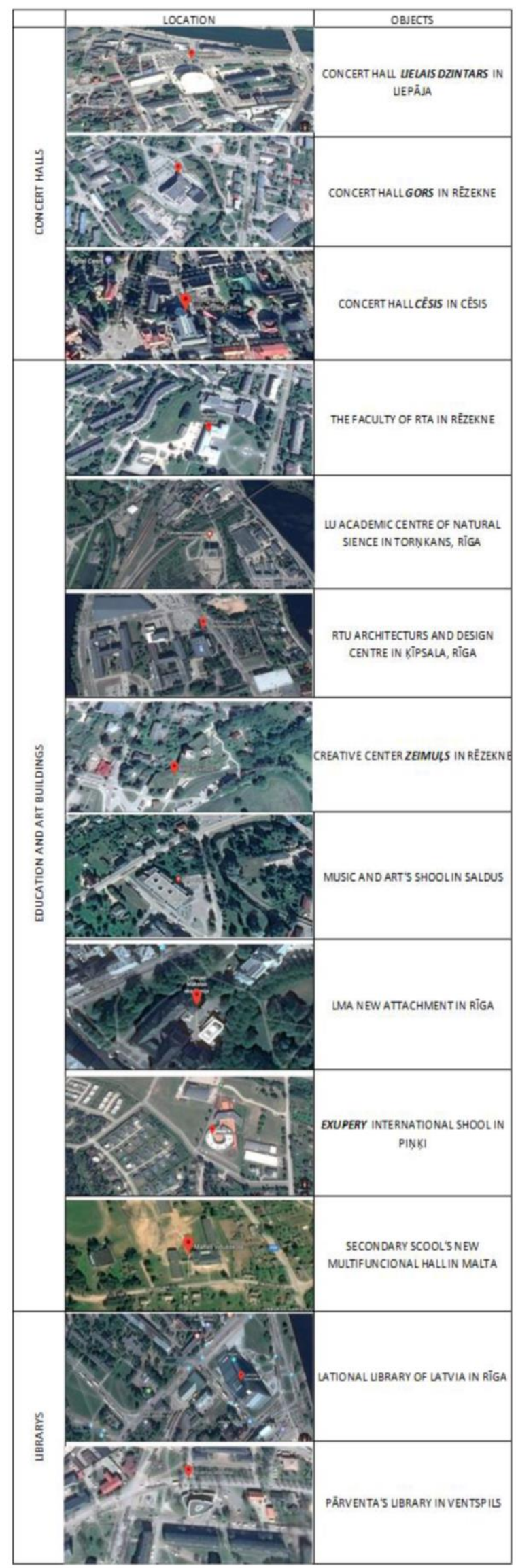


point to the landscape space as a living painting in the corridor's interior. A powerful impression has been achieved by using a ledge leading to the glassed plane that connects the park with the inner space, creating a "painting" in the background of the State Art Museum. In turn, in the upward sight point from the staircase, a "painting" with the sky is readable.

As the second of the criteria, the compositional use of colors and chiaroscuro in interiors was analyzed in the effects of the sunshine. The artistically powerful idea is brought to the orange outer glass planes in the interiors of the concert hall "Great Amber" in Liepāja. Thanks to the sunshine, it brings a surreal character to the interaction between the outer space and the inner space. As the sun moves in its rhythm, all the inner space adjacent to the outer space lights up one by one, thanks to glazing and the shape of the building volume that resembles an overturned, truncated pyramid segment. Due to the sunshine, the mood of the interiors is changing. As seasons change, the silhouette and colors adjacent to the greenery change, which cyclically refreshes the interior with a new colorful mood. The benefits of Latvia's natural beauty in interiors have been successfully used in the interior of the lobby of the Faculty of Engineering at Rezekne Academy of Technologies, in the auditoriums and workshops of Architecture and Design Center of Riga Technical University, in the Rēzekne "Zeimulss" workshops, and in the classrooms and recreation rooms of the Exupery International School in Pinki (Rīga).

As the third of the criteria, the visual accents of the chiaroscuro game were analyzed in the interiors. The newest annex of the Academy of Arts with a passage looking like a tunnel with the light at the end is most prominent in this category. The spatially extended proportions and the rough gray concrete wall finish, as a result of the chiaroscuro game, obtain a more dramatic character that contrasts with the scenic landscape in the outer space.

The fourth criterion that was under the analysis was the semantic correspondence between the outside space and the inner space. The urban landscape space, semantically complementary to the interior, best of all is manifested in projects where artistically high architectural tasks are implemented. Here, we have to mention Liepāja Concert Hall in the diverse urban landscape space, which emotionally engages art life in the urban rhythm and opens the art to the sound of an uproar of the adjoining quarters and streets. The National Library of Latvia should be noted, in the interior of which the silhouettes of Old Riga and the river Daugava semantically magnificently manifest their presence [5]. The academic study center for natural sciences semantically meets the greenery of Tornakalns, mutually complementing each other. The creative center "Zeimuls" on the green, low hill brings a semantic harmony with its natural plastic and serene peace of mind that is needed for creative performers.

As the fifth criterion, the context of the architectural form creation of the site in the landscape space was analyzed. The percentage psycho-emotional quality assessment is used not only for the purpose of a mutual comparison of sites but also for obtaining two-way research results:

- the language of form creation of the landscape space and architecture - the search of the context of the landscape space and the indoor space. The results of the percentage evaluation of the psycho-emotional quality in the gradation from $100 \%$ (for the assessment of the interaction of the destructive interiors and the landscape space) to $+100 \%$ (for the harmonic integration of the interiors with the landscape space assessment) are shown graphically (Fig. 2).

Evaluating each of the above-mentioned sites, in detail, the context of the sites of the landscape space and the architecturally-compositional structure are considered. The workshop rooms of Saldus Art School are visually matched with the space of creative activities located in the outdoor space, which serves not only for art classes but also for the location of expositions. In turn, in the southern part of the space, there is a recreation or relaxation space with loungers and small plantations of small trees. The aforementioned outdoor space of the school is located near the picturesque bank of the river Ciecere, linking the creative activity around the school to the riverbank meadows. A semi-circular landscape space around the school building is formed that spatially unites activities, relaxation, and the ecological core.

A similar harmony of the architectural character and the landscape space is readable in Rezekne Art School "Zeimuls"s". Visually, the overall emotional harmony is created by sloping green roof planes, which expressively complement the side-by-side relief game on the western edge. In turn, on the eastern side of the building volume, there is a bank of the river Rēzekne with separate groups of trees, thus forming a context with its green roofs on the opposite side of the building. With the change in the seasons, tree color, the picturesqueness of the compositional space changes in the main sight points. A very similar compositional change of the landscape space is typical for the building of Faculty of Architecture and Urban Planning of Riga Technical University. Its southern facade is hidden in a birch grove, the foliage of which changes in seasons, each time changing the dark facade finishing. The change of the external image of the 
construction volume creates an intrigue and many facets of both immediate and distant sight points. The simulated plant vein in the facade of the building of Academic Center for Natural Sciences is particularly well readable in the artificial lighting. Visually powerful is the sight point, while in between the building and the green area of the Kileveina ditch: on one side of Vienības gatve - a group of woody plants of the Kileveina ditch but on the opposite side of the street - the facade plant vein desiring to butt together to form a simulated green canal, which brings you into the city. The pronounced symmetry of the building of the Faculty of Engineering of Rezekne Academy of Technologies is increased by a semi-circle front varea with a longitudinal axis where the semi-circle of the eastern edge is introduced by a large group of trees. The Ventspils library, situated in between Tārgale and Ozolu streets, has a wide front square, which is separated from the library building by a dense group of trees. The green tree crown mass creates an intrigue for the perception of two different scales of the urban construction space. The factors of a harmonious interactivity can be divided into three influential basic blocks:

- The quality block of the architectural and compositional environment (the structure of the architectural and spatial planning, the perception of the panorama and silhouette, the semantic relevance of the outdoor and indoor space).

- The block, covering the role and impact of the natural factors on the structures of the architectural design of the urban environment (water basins, the relief, the green system, seasons).

- The block, covering the activity of the gravity field of the urban environment in the settlement system (the factor of the service sector, the factor of attracting tourists, the factor of the cultural and historical heritage).

They are mutually closely linked and in a dynamic interaction. A decisive role in the interaction of multi-factors is played not only by a successful cooperation of specialists but also by the contracting authority, legislation, and engineering communications (Fig. 3).

\section{THE AVERAGE RATING OF LANDSCAPE SPACE AND INDOORS FROM THE PERSPECTIVE OF EXPERT}

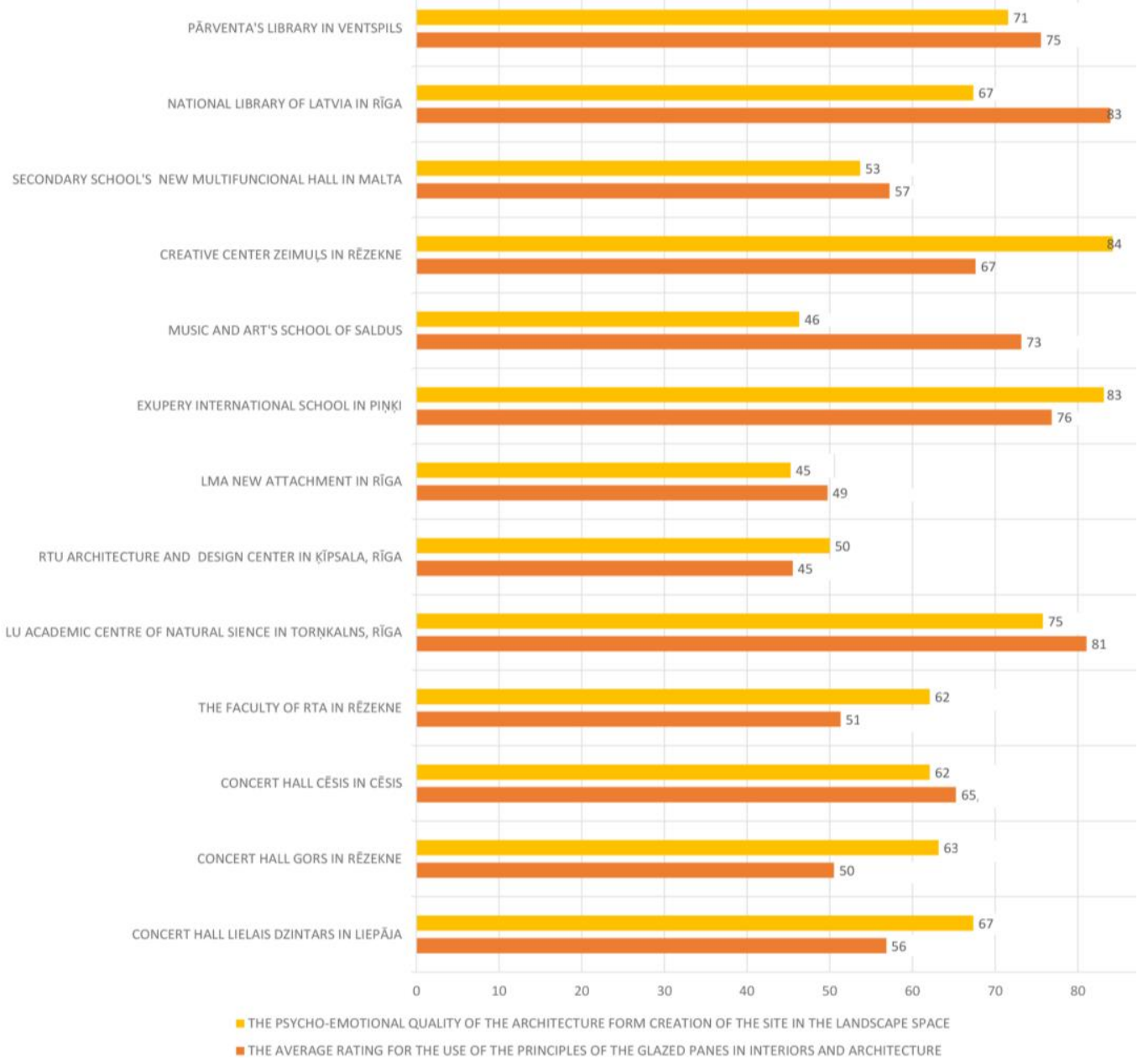

Fig. 2. The mutual comparison of the external and internal criteria creating harmony of the landscape space, architecture, and the interior of various sites [created by the authors, 2017] 


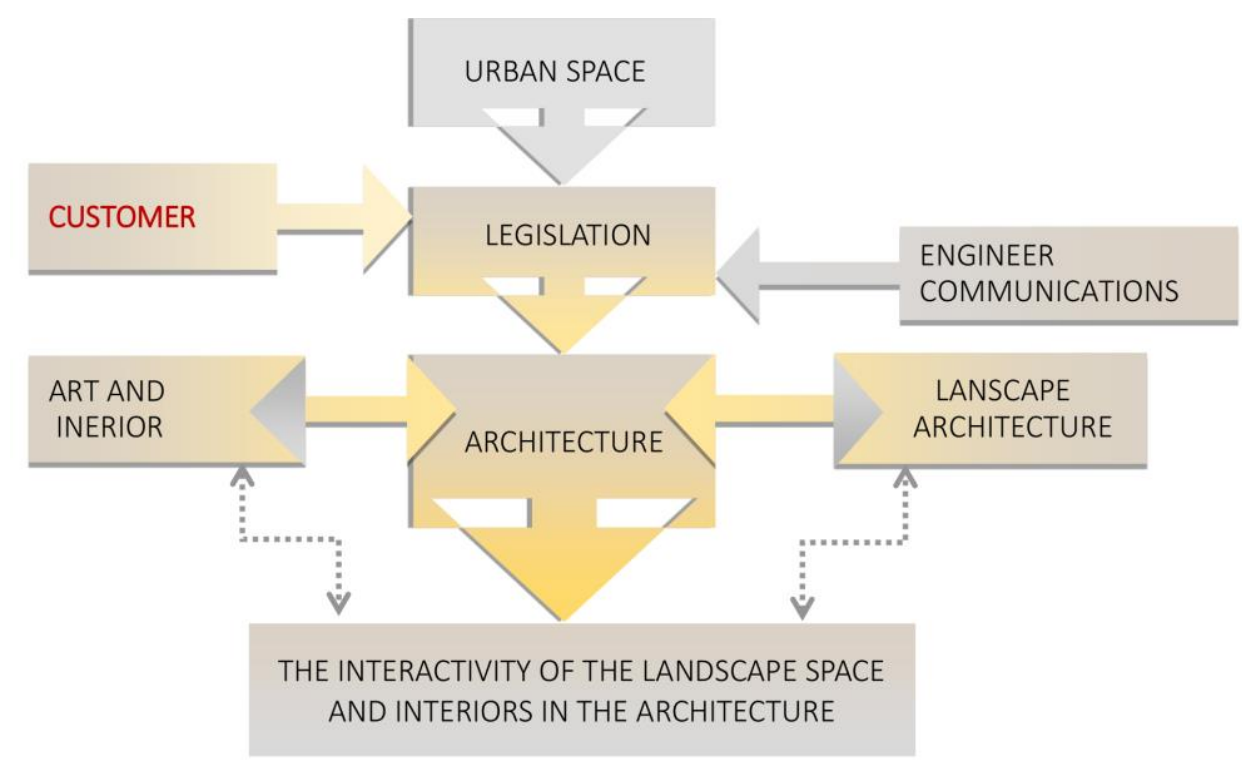

Fig. 3. The aspects forming harmony of the landscape space, architecture, and interior of the urban environment [created by the authors, 2015]

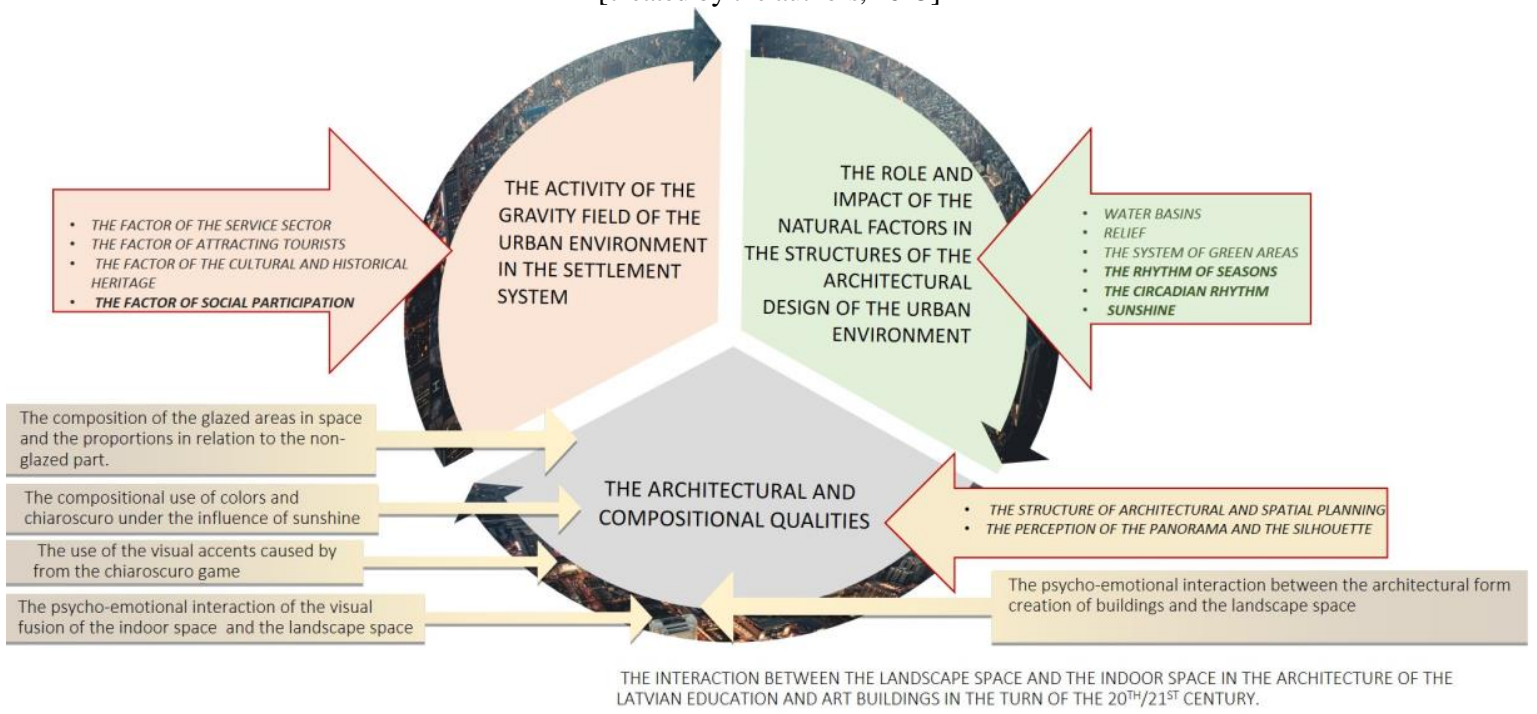

Fig. 4. The criteria of the aesthetic and informative qualities of the art of space creation, consisting of landscape architecture, architecture, and interiors, the author's created, 2017 [according to Brinkis, Buka, 2006; created by the authors, 2017]

\section{Conclusions}

The visual, aesthetic, and psycho-emotional quality of architecture in the landscape space of Latvia and in the architecture of art buildings, linking the interior and the landscape space with widely glazed planes, generally is rated as very good, often showing remarkable results. Excellence in the assessment of the psycho-emotional quality of architecture is reached by sites with integrated, high artistic value, appropriate to the function with the interior and a corresponding landscape space secondary to it.

The results obtained during training at the educational establishments confirm that outdoor and indoor dialog creates a new architecturally landscaped space. The close linking of nature and the interior in the recreational and transit zones is one of the keys of the outdoor and indoor harmony in educational institutions.

In libraries, excellent results can be achieved, combining the light shafts, tunnels, skylights, the reflected light with traditional window planes in facades if the second ones are alternative to the first ones in terms of light intensity.

The study confirms the efforts to find harmony not only with nature in the art of creating the environment but also in the interaction of the landscape space and the indoor space, keeping pace with the scientific developments.

The implementation of the artistically stylistic concept that is alternative at the interdisciplinary level is the most important mission of the environmentalists in the interaction of a harmonious 
landscape space and the indoor space, to which, in turn, the psychologically emotional and material tasks are subordinated. The architectural and spatial proportions in the interaction of the landscape space and the indoor space in an artificial environment, balanced with the ecological core are a powerful tool in attaining high artistic and stylistic objectives in the art of building the environment. The impact of natural conditions on the interaction of the landscape space and the indoor space through the game of chiaroscuro, sunlight, and color, in an artificially created environment is vitally important and appropriate to use in attaining high artistic and stylistic objectives in the art of building the environment and raising the psycho-emotional quality of architecture.

\section{References}

1. Alle, E. Mūsdienu māksla Latvijas kultūrainavā [tiešsaite]. Promocijas darbs Arhitektūras doktora (Dr. arch.) zinātniskā grāda iegūšanai ainavu arhitektūras apakšnozarēe LLU [skatīts 08.19.2016]. http://llufb.llu.lv/promoc_darbi.html?i=promoc_darbi_freims.html\&c=Alle

2. Spriṇge A. Arhitektūra, kas sasilda un atvēsina pilsētas. Saruna ar arhitektu Jakobu Kureku [tiešsaite]. Pastaiga. [skatīts 10.12.2017]. http://jauns.lv/raksts/pastaiga/262714-arhitektura-kas-sasilda-un-atvesina-pilsetas-saruna-ararhitektu-jakobu-kureku

3. Briṇķis, J. Reǵionālās attīstības arhitektoniski telpiskie aspekti. RTU Zinātniskie raksti: 10. Sērija: Arhitektūra un pilsētplānošana. Rīga: RTU, 2007, 1. sēj., 101.-109. lpp.

4. Grietēna, A. Glass as means of indoor/outdoor communication in architecture. Scientific Journal of Latvia University of Agriculture. Landscape Architecture and Art. Jelgava: LLU, 2015, Vol. 6, Nr 6, p. 58-67.

5. Grietēna, A. Study of Harmony in the Indoor / Outdoor Context of Architecture from G. Birkerts at the new building National Library of Latvia. Scientific Journal of Latvia University of Agriculture. Landscape Architecture and Art. Jelgava: LLU, 2014, Vol. 5, p. 48-57.

6. Jencks, C. Architecture becomes music [online]. Architectural Review, May 2013. Vol. 233, p. 91-108. [cited 7.12.2013] http://web.ebscohost.com.ezproxy.llu.lv/ehost/detail?vid=5\&sid=e7587d84-8bc1-4686970139967f6fbea5\%40sessionmgr114\&hid=4212\&bdata=JnNpdGU9ZWhvc3QtbGl2ZQ\%3d\%3d\#db=asu\&AN=87 467917

7. Jencks, C. God, the Architect of the Universe - Universe, the Architect of God [online]. Center: Architecture \& Design in America, 2010. 19 p. [cited 4.12.2013]. https://ezproxy.llu.lv/login?qurl=http://web.ebscohost.com $\% 2$ fehost $\% 2$ fdetail\%3fvid\%3d8\%26sid\%3de7587d84-8bc1-4686-970139967f6fbea5\%2540sessionmgr114\%26hid \%3d121\%26bdata\%3dJnNpdGU9ZWhvc3QtbGl2ZQ\%253d\%253d\#db=asu\&AN=82876453www.1lu.lv

8. Jencks, C. The New Paradigm in Architecture [online]. Architectural Review, February 2003. Vol. 213, p. 72-77. [cited 6.12.2013] https://ezproxy.llu.lv/login?qurl=http://web.ebscohost.com\%2fehost $\% 2 \mathrm{fdetail} \% 3 \mathrm{fvid} \% 3 \mathrm{~d} 7 \% 26 \mathrm{sid}$ \%3de7587d84-8bc1-4686-9701-39967f6fbea5\%2540sessionmgr114\%26hid\%3d121\%26 bdata\%3dJnNpdGU9ZWhvc3QtbGl2ZQ\%253d\%253d\#db=asu\&AN=505047624

9. Strautmanis, I. Dialogs ar telpu. Rīga: Liesma, 1977, 136 lpp.

10. Strautmanis, I. Dzīve arhitektūrāa. Rīga, RTU izdevniecība, 2007, 137 lpp.

11. Strautmanis, I. Māksla arhitektūrāa. Rīga: Liesma, 1982, 103 lpp.

12. Visu gadu uzvarētāji [tiešsaite]. Latvijas Arhitektūras savienība [skatīts 10.10.2017]. https://www.latarh.lv/gadabalva/visu-gadu-uzvaretaji/

13. Ziemeḷniece, A. Context seeking of cultural heritage and green struckture in urban environment. Scientific Journal of the Latvia University of Agriculture: Landscape Architekture and Art. Jelgava: LLU, 2012. Vol. 1, p. 67-73.

14. Zigmunde, D. Estētiskās kvalitātes kritēriji urbanizētas ainavas izpētē. LLU Raksti: LLU Arhitektūras un būvniecības katedra. Jelgava: LLU, 2010, 25 (320), 1.-12. lpp.

15. Zigmunde, D. Latvijas urbānās un lauku ainavas estētiskā un ekologiskā mijiedarbe. Promocijas darba kopsavilkums. Jelgava: LLU, 2010. 84 lpp.

16. Большакова, И. Современные проблемы объединение внешних и внутренних пространств [online]. «Архитектон: известия вузов», № 42, приложение, сентябрь 2013 [cited 10.02.2015]. http://archvuz. $\mathrm{ru} / 2013 \_22 / 70$

17. Власов, В. Дизайн - архитектура и 21. век [online]. «Архитектон: известия вузов» № 41, март 2013 [cited 10.02.2015]. http://archvuz.ru/2013_1/1

18. Гликин, Я.Д. Методы архитектурной гармонии. Ленинград: Стройиздат, Ленинградское отд., 1979. 95 стр.

19. Швидковский, О.А. Гармония взаимодействия. Москва: Стройиздат, 1984. 279 стр.

\section{INFORMATION ABOUT AUTHORS:}

Aija Grietēna graduated in Architectural Sciences - Master of Architecture and Planning. At 2012 Aija Grietēna started Doctoral studies in Latvia University of Agriculture. E-mail: aijagrietena@ gmail.com Aija Ziemelniece, Dr.arch., Professor at the Faculty of Environment and Civil Engineering, Department of Landscape Architecture and Planning of the Latvia University of Agriculture, 22 Liela iela, Jelgava, Latvia, LV-3001. E-mail: aija@k-projekts.lv

Una İle, Dr. arch., Assist. Prof. (since 2012) at the Faculty of Environment and Civil Engineering, Department of Landscape Architecture and Planning of the Latvia University of Agriculture, 22 Liela iela, Jelgava, Latvia, LV-3001. E-mail: una.ile@1lu.lv 
Kopsavilkums. Darba teorētiskā un praktiskā nozīme ir psihoemocionāli harmoniskākas un augstvērtīgas telpiskās vides veidošana Latvijā, kvalitatīvāk sadarbojoties arhitekturas, ainavu arhitektūras un interjeru speciālistiem. Veiksmīgi sadarbojoties ainavu arhitektiem, arhitektiem, interjeristiem un dizaineriem, ir radīta virkne mākslinieciski augstvērtīgus vides objektus, kam raksturīga vides viengabalainība jeb veselums, tādējādi fragmentāri uzlabojot pilsētbūvnieciskās ainavtelpas kvalitāti. Latvijas un starptautiskiem ekspertiem sadarbojoties, šai ziņā īpaši novērtētas trīs koncertzāles, divas bibliotēkas, astoņas izglītības ēkas.

Vizuāli estētiskā un psihoemocionālā arhitektūras kvalitāte Latvijas ainavtelpā izglītības un mākslas ēku arhitektūrā, kopumā vērtējama kā l,oti laba, nereti uzrādot izcilus rezultātus. Izcilību arhitektūras psihoemocionālās kvalitātes vērtējumā sasniedz objekti ar integrētu, funkcijai atbilstošu augsti māksliniecisku vērtību.

Izglītības iestāžu pētījumā iegūtie rezultāti apstiprina, ka ārtelpas un ainavtelpas dialogs veido jaunu risinājumu meklējumu virzienu. Dabas pamatnes elementu un arhitektūras formveides cieša sasaiste rekreācijas un tranzīta zonās ir viena no harmonijas atslēgām izglītības iestādēs. Ainavtelpas turpinājums iekštelpā mākslas un izglītības ēkās ir iegūstams, kombinējot gaismas šahtas, tuneḷus, virsgaismas, atstarotās gaismas ar tradicionālām logu plaknēm fasādēs, ja otrās pakārtotas pirmajām gaismas intensitātes ziņā.

Pētījums apstiprina centienus rast harmoniju ne tikai ar dabas elementiem vides veidošanās mākslā, bet arī ainavtelpas un ēkas arhitektūras mijiedarbē ejot kopsolī ar zinātnes sasniegumiem. Māslinieciski stilistiskās koncepcijas realizācija, kas pakārtota vizuāli estētiskās kvalitātes uzdevumam starpdisciplinārā līmen̄̄, ir svarīgākais vides veidotāju virsuzdevums iepriekš minētajai mijiedarbei, kurai pakārtoti psiholog̣iski emocionālie un materiālie uzdevumi. Arhitektoniski telpiskās proporcijas ainavtelpā, kas sabalansētas ar dabas pamatni, ir spēcīgs līdzeklis augstu mākslinieciski stilistisku mērķu sasniegšanā vides veidošanas mākslā. Dabas elementu konteksta meklējumi, gaismēnu spēle, izsauļojums, gadalaiku kolorīts un kokaugu dendrologiskās īpatnības ir nozīmīgs un lietderīgi izmantojams kritērijs, kas veido svarīgu lomu arhitektūras psihoemocionālās kvalitātes celšanā. 


\title{
The quality of the public open space in Engure village in Latvia
}

\author{
Anna Kalniņa, Natalija N̦itavska, Latvia University of Agriculture
}

\begin{abstract}
The role and significance of the public open space in the world in the context of urban and populated areas is increasing and becoming important among both for professionals of related areas and for the population. The relevance of this topic in Latvia has also increased in recent years. Public open space is one of the most important aspects of the quality of the living environment, which affects the economic and sociological factors of the place. It creates the identity of the place and characterizes the society that makes it and resides there. The public open space of Engure village is evaluated in the research. Engure village is one of the coastal fishing villages in Latvia, which was formed in the $2^{\text {nd }}$ half of the $13^{\text {th }}$ century, later developing as one of the small port villages on the western coast of the Gulf of Riga. There are about 1500 inhabitants in Engure, but in the summer season, the village becomes a favorite destination for tourists and holidaymakers. Using the comparative method for the analysis of the scientific literature in the research, main determining factors of the public open space were defined and the basic criteria for the assessment of the quality, accessibility and functionality of the open space were selected. Through the evaluation of the public open space of the village, gained results reflect the quality of the public open space of Engure village, which is characterized by the availability of the place, the overall evaluation of general improvement, the greenery and the environmental quality.
\end{abstract}

Keywords: public open space, quality, accessibility, coastal landscape

\section{Introduction}

The public open space is a freely available area and space for everyone. Such public areas as streets, boulevards, roads, squares, parks, city gardens, courtyards, embankments, passages, promenades and other places that have been placed for public use irrespectively of their property ownership are considered as a public open space [15]. The public open space forms in dependence to various changes and processes that take place in the placesociological, political or economic. The factors that determine the frequency of the use of a place are its quality, which includes the location in the populated area and its function, accessibility, approachability, shape, size, aesthetic quality and attractiveness, views, climate and elementsof amenities $[8 ; 7 ; 6]$. The quality of the public open space is regarded as an important urban environmental factor, as the public open space itself is one of the main basic elements of the structure of this environmental landscape. In the same way, with its functionality and a set of activities possible to do in the place, it is a significant indicator of the quality of living environment of the surrounding population, the basis of mental and physical health [12].

One of the most urgent issues in researches of the public open space in recent years is how to evaluate the most important of the public open space determining factors, which should be considered as the basic factors determining the quality of the public open space and how to evaluate these factors. According to the research conducted by PPS (nonprofit organization "Project for public space"), the four basic factors that make up the public open space are defined accessibility, comfort or environmental quality, function and social environment $[9 ; 16]$.

In rural areas, the role of the public open space is more economical than recreational, it is an open space where trade takes place - in the markets and in storefronts, or events, it is a place of rendezvous that solves necessary everyday needs, such as moving from work to home, waiting. Nature territories that are characterized to the structure of rural settlements, are mainly used for recreation, forming the uniqueness, identity of the place, natural, cultural and historical values, on the basis of which hiking trails and natural tourism objects as public open spaces are being developed, which becomes a significant contributor to the economic factors of a local municipality [10]. The public open space is not only a place for society activities and the provision of functional needs, but it also forms a general visual image and identity of a populated area, characterizing the populated area, its inhabitants, traditions and values. In the absence of the public life and the public open space, the emotional connection of the inhabitants to the place is reduced $[11 ; 2]$.

By providing the satisfaction of some physical and psychological needs of every individual who visits and resides in the public open space, promoting the improvement of the quality of the living environment to the populated area as a whole, the public open space creates the economic and social common benefit that refers both to every citizen and visitors of the place, as well as to the populated area as a whole. Three main factors determining the quality of the populated area are the physical, economic and social environment. 


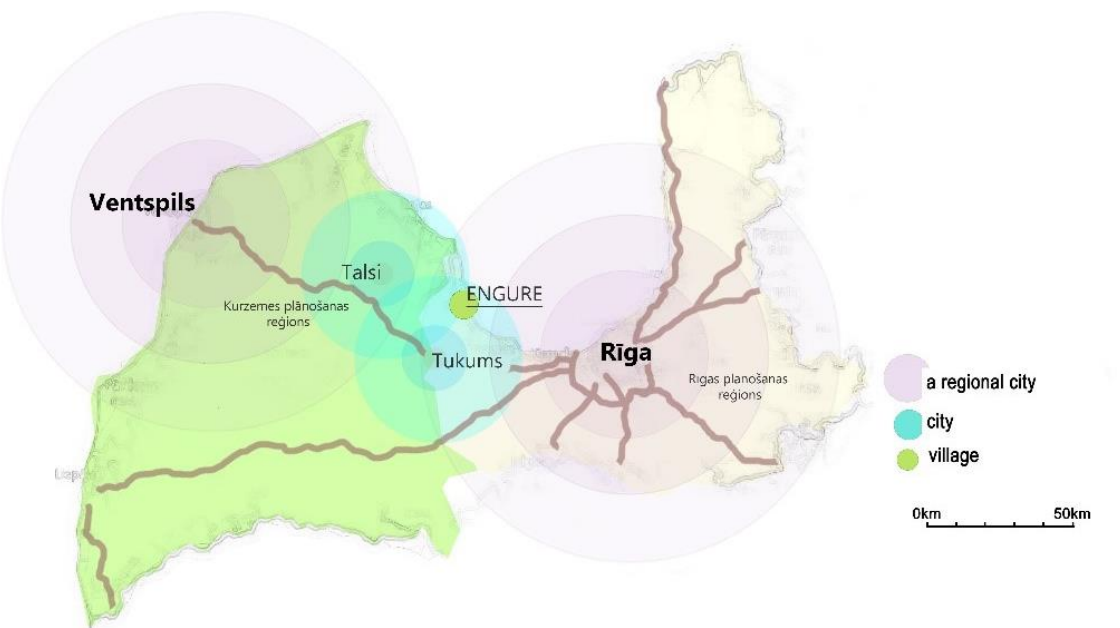

Fig. 1. Engure village on the map of Latvia [created by the authors]

The public open space is an integral part of the structure of the populated area, an integral part of the physical environment, which can also provide a positive increase of the factors affecting a social and economic environment in the populated area [12].

The public open space has been studied in the world extensively. It has become one of the topical themes among urban planners, architects and landscape architects in recent decades. The first public open space researches were carried out in the middle of the $20^{\text {th }}$ century, and as well-known researchers of the public open space are Jane Jacobs, Jan Gehl and William H. Whyte [5]. Researches of the public open space in Latvia were made relatively small, although the processes of its design and development happen every day. In regard to the coastline in the field of the landscape architecture there has been conducted a research on the identity of the coastal landscape of the Baltic Sea so far [13]. Studies on the public open space on a Latvian scale are mainly made on a city scale and on the field of spatial planning. One of the most comprehensive and largest research about the public open space has been carried out to Riga - "Development of the guidelines for the provision of greening structures and public open space networks in Riga" (2014-2015) [14].

Both in Latvia and in the world the public open space is rarely considered as an important part of rural (populated) areas. Rural areas of Latvia are becoming less populated in recent years, influenced by both social and economic conditions and urbanization processes in general. The quality of the public open space as one of the tools for improving the quality of the living environment can be a significant factor contributing to the return of the population to rural villages and cities.

Engure village on the West Coast of the Gulf of Riga was selected as a research object. The coastal landscape and the historically developed cultural environment is one of the fundamental aspects that characterizes not only Engure village and its public open space, but also the identity of the coastal landscape and environment of Latvia. It is a landscape rich of folk traditions and historical events, with coastal fishing villages and small towns were developed in the $19^{\text {th }}$ and $20^{\text {th }}$ centuries as economically developed coastal areas, today have become an integral part of the coastal landscape and a significant part of the structure of the populated areas for sustainable development of the country. The natural and cultural historical values of the place, geographical location and cultural heritage with folk traditions make Engure as a potential final destination for holiday or place of residence.

The purpose of the research is to analyze the public open space made structure of Engure village and its fundamental factors as functionality, quality and accessibility, as a result to understand the constituent factors of the surrounding factors and their characteristic criteria, the spatial structure created by the public open space in the populated area. As a result, defining the improvements of the structure of the public open space of the village as a means of promoting the quality of the living environment and positively affecting the social and economic aspects of the populated area.

\section{Objects}

Engure is located in the district of Engure and is one of the largest villages in the district and is a part of the Riga planning region. Engure is located $70 \mathrm{~km}$ from the capital of Latvia, Riga (Fig. 1). Engure is a district service center, crossed by a regional highway, the village has 1580 inhabitants [3], which has a tendency to increase during the summer season at the expense of holidaymakers.

The historical development of Engure dates back to the $2^{\text {nd }}$ half of the $13^{\text {th }}$ century - in 1245 the name of Engure was mentioned for the first time in the chronicles as a Liv settlement on the Lake of Engure. The economic and rapid development of the village is mainly related to the $17^{\text {th }}$ century - the reign of Duke Jacob. During this time extensive economic activities, trade and provision of export 


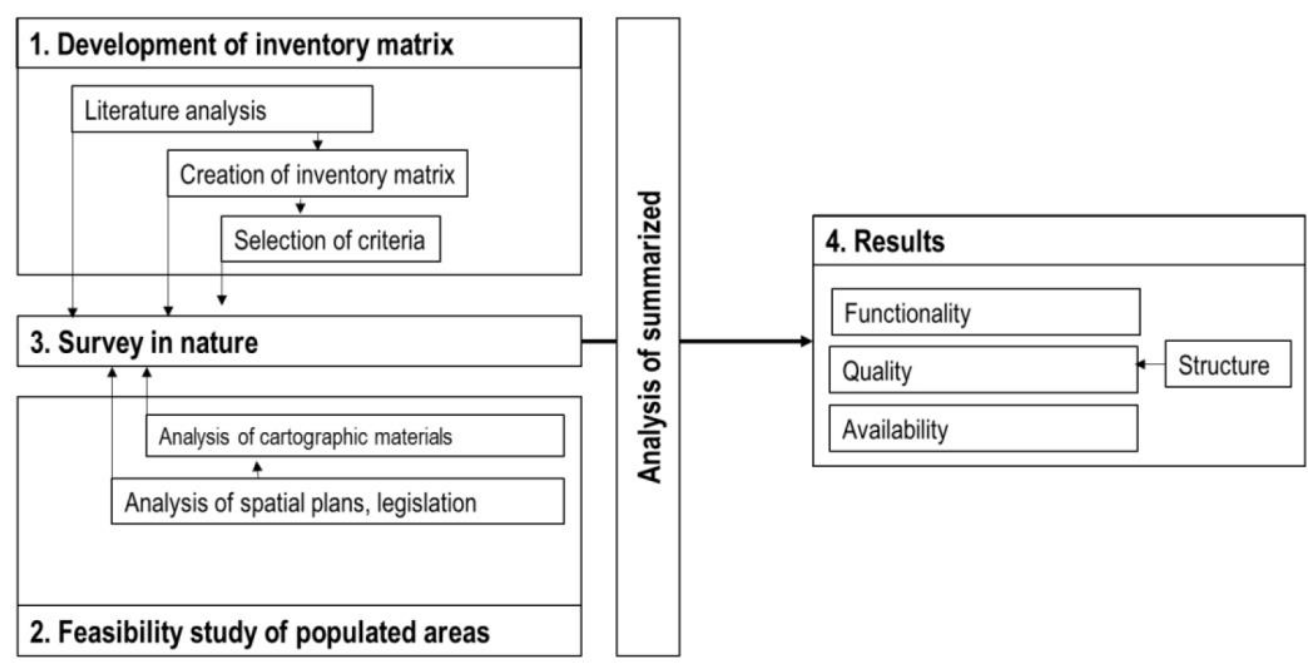

Fig. 2. The research process map [created by the authors]

services took place in the village, thus developing Engure as one of the small ports on the coast, for the needs of the Duchy of Courland [4].

Fish processing, fishing, parish administration, retail trade, logging and conversion and wood processing, agricultural production as the main areas of activity of the population are mentioned in the national economy. Historically the port should be mentioned as one of the largest and most important drivers of economic development. The port of Engure today has mainly become a tourist port, focusing on yachting tourism, docks of small fishing boats. The village has educational institutions such as kindergarten, high school, music and art school. Traditional cultural institutions as a folk house or cultural center, a meeting room with a museum, a library, a youth center. An important role in the cultural, tourism and recreation field of coastal villages has the traditional fishermen's festival, various art festivals, ancient fire nights, green balls that attract large number of visitors and guests in the summer season [3].

\section{Method}

In order to evaluate the public open space of Engure village, an overall assessment of its quality, availability, functionality and structure in the populated area, an inventory matrix was created and a survey in nature was conducted, aggregating 10 public open spaces in total. Excel software was used for analysis and interpretation of the gained data, results. The total period dedicated by the research is from autumn 2015 to spring 2017.

The research process is divided into 4 stages (Fig. 2), certain intermediate results were gained after the completion of each stage, which determined the beginning of the next stage. Each stage has to be done in sequence in order to carry out the next stage completely.
The research process can be divided into the following stages:

1. Selection of criteria characterizing the basic factors and sub-factors and creation of inventory matrix;

2. Feasibility study of populated areas;

3.Survey in nature;

4. Analysis of summarized data and results. Stage 1

The theoretical basis of research includes an analysis of scientific literature and monographs in order to understand the basic factors creating the public open space. On the basis of the defining fundamental factors forming the public open space, which are further subdivided into sub-factors, an inventory matrix is created and criteria are selected that characterize each of the sub-factors (Fig. 3).

The quality, availability and function of the public open space are defined as the key factors forming the public open space. According to the analysis of the scientific literature, the basic researched factors and the most appropriate criteria for the development of an inventory matrix were selected, derived from the methods applied in J. Gel and the PPS research, adapting them to the conditions of this research, identifying the factors to be investigated, which can be surveyed and inventoried in a short period of time in order to obtain a general but comparable view of the overall quality of the public open space.

\section{Stage 2}

In advance of performing the survey, in the process of feasibility study, it is necessary to identify the potentially surveyed public open spaces, their location and historical development, in order to be able to fully explore the place in nature and recognize the values of the place - landscape, cultural, historical, ecological. This was done by 


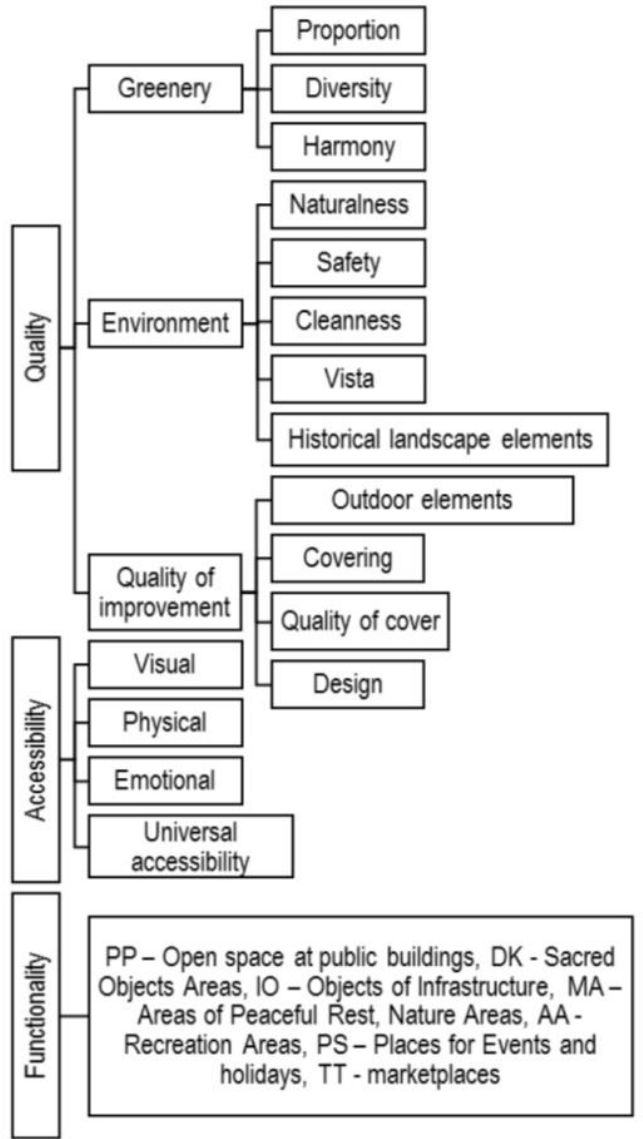

Fig. 3. Factors which forms public open space [created by the authors]

analyzing and exploring cartographic imagery of the populated area - a map, aerial photographs of the village, Google Street images, graphic materials and explanatory descriptions of the spatial planning of the district, available historical photographs and historical evidence in archives.

\section{Stage 3}

The observation was selected as a main research tool - a survey in nature, which helps to capture the social life of the public open space and form a set of its activities [5; 16]. In this way, all the data needed to complete the study inventory matrix are collected.

Being on the place, following the pre-mapped public open spaces, there were inventoried all areas freely accessible and visible from the main village streets or indicated by indication signs in the village. Such areas as parking lots - recreational areas, squares at public buildings, piers, freely accessible port areas, hiking trails, beach, open air estates, areas near the churches, marketplaces were surveyed in the research.

The inventory matrix was filled on site assigning a certain number of points to each of the underlying sub-factor according to the given criteria. In order to obtain an evaluation of the public open space, subfactors (greenery, environment, quality of improvement, visual, physical, emotional, universal accessibility) for each basic factor (quality, accessibility, functionality) are distinguished, which, according to its characteristic features, are evaluated for a point on a scale from 0 to 4 , giving it the appropriate clause for a point value or critera (Table 1; Table 2).

By evaluating the function of the public open space, they are identified by type, thus defining the basic function of the open space. Open spaces are divided by type according to the functional open types created by S. Carr [2]. By adjusting and combining types according to the types of open spaces found in villages, the following functional modes of the open space are distinguished in research: $\mathrm{PP}-$ Open space at public buildings, DK - Sacred Objects Areas, IO - Objects of Infrastructure, MA - Areas of Peaceful Rest, Nature Areas, AA - Recreation Areas, PS - Places for Events and holidays, TT - marketplaces. By the graphical analysis method, analyzing and mapping the location and functionality of the public open space in the village, a map of the structure of the public open space was created. It maps the surveyed public open spaces by their functional division and deplores the area of the central part of the village of $1 \mathrm{~km}^{2}$, determined on the basis of the amount and type of the public open space, defining village service centers.

In addition, during the process of the survey, a photo fixation of the place was made and the public open space was marked on the previously prepared aerial photography of the village. The survey of the public open space for Engure village was made within one day.

\section{Results}

\section{Functionality}

A map of the structure of the public open space was created by examining, analyzing and mapping the location and functionality of the public open space in the village (Fig. 4). It maps the surveyed public open spaces by their functional division and deplores the area of the central part of the village of $1 \mathrm{~km}^{2}$, determined on the basis of the amount and type of the public open space, defining village service center, which plays an important role in the development of sustainable and balanced populated area and in the development of place of economic, social, cultural activities and public interest of a certain area [1].

The structure of Engure village is characterized by a distinctly centric construction, arranged by public open spaces of various functions, such as open spaces at public buildings, infrastructure objects, events, holidays and market areas, in the central part, within a short distance from each other. In the outskirts of the village, creating areas of peaceful rest, nature areas, which is explained by the existing spatial plan of the village - the development 
Characteristic features of public open space quality [created by the authors]

\begin{tabular}{|c|c|}
\hline \multicolumn{2}{|c|}{ Quality (max -37 points) } \\
\hline Characteristic feature & Points - criteria \\
\hline \multicolumn{2}{|c|}{ Greenery (max - 10 points ) } \\
\hline Proportion & $\begin{array}{l}4 \text { - More than half of the territory consists of greenery or natural base; } 3 \text { - Less than half } \\
\text { of the territory consists of greenery or natural base; } 2 \text { - Less than } 1 / 4 \text { of the territory } \\
\text { consists of greenery or natural base; } 1 \text { - Less than } 1 / 10 \text { of the territory consists of } \\
\text { greenery or natural base. }\end{array}$ \\
\hline Diversity & $\begin{array}{l}\text { 3-The diversity and richness of the plant species, plant species typical of the region; } 2 \text { - } \\
\text { Small variety of plant species, plant species suitable for the region; } 1 \text { - The diversity and } \\
\text { richness of the plant species that are not characteristic of the region. }\end{array}$ \\
\hline Harmony & $\begin{array}{l}\text { 3- Greenery are in harmony with the environment; } 2 \text { - Greenery are interconnected, but } \\
\text { not in harmony with the environment; } 1 \text { - Greenery are made chaotic and unprofessional } \\
\text { or non-functional or Not specially made greenery / natural base. }\end{array}$ \\
\hline \multicolumn{2}{|c|}{ Environment ( $\max -15$ points) } \\
\hline Naturalness & $\begin{array}{l}3 \text { - Semi-natural or natural environment with minimal infrastructure; } 2 \text { - An environment } \\
\text { similar to the urban environment; } 1 \text { - Erosion-affected, degraded area or degraded } \\
\text { environment. }\end{array}$ \\
\hline Safety & 3- Safe; 2- Insecure in certain cases or groups of society; 1- Insecure. \\
\hline Cleanness & $\begin{array}{l}\text { 3- Clean environment, there are waste containers and urns; } 2 \text { - There is no waste } \\
\text { containers or urns, but the place is not dirty; } 1 \text { - Dirty environment. }\end{array}$ \\
\hline Vista & $\begin{array}{l}3 \text { - Expressive and beautiful landscape views or surrounding; } 2 \text { - There are no beautiful } \\
\text { views, but the surroundings are attractive and pleasant, well-organized; } 1 \text { - Views and the } \\
\text { environment around is degraded or is not pleasant or there are potentially landscape-rich, } \\
\text { sight-seeing views that are hidden. }\end{array}$ \\
\hline \multicolumn{2}{|c|}{ Quality of improvement (max -12 points) } \\
\hline Outdoor elements & $\begin{array}{l}3 \text { - All kind of necessary outdoor elements; } 2 \text { - Almost all kind of necessary outdoor } \\
\text { elements; } 1 \text { - There is no required outdoor elements. }\end{array}$ \\
\hline Covering & $\begin{array}{l}\text { 3- Separate pedestrian, cycling and road transport zones; } 2 \text { - Separate pedestrian and car } \\
\text { parking area, but no separate bicycle path; } 1 \text { - There are no separate pedestrian, cycling } \\
\text { and road vehicle zones. }\end{array}$ \\
\hline Quality of cover & $\begin{array}{l}3 \text { - Functional, good quality, coherent design; } 2 \text { - Functional but not qualitative or non- } \\
\text { functional and qualitative; } 1 \text { - There is no appropriate cover quality and functionality. }\end{array}$ \\
\hline Design & $\begin{array}{l}\text { 3- Interconnected outdoor elements, in harmony with the environment; } 2 \text { - Interconnected } \\
\text { outdoor elements, but not in harmony with the environment; } 1 \text { - The elements of the } \\
\text { improvement do not have a uniform design. }\end{array}$ \\
\hline
\end{tabular}

Characteristic features of public open space accessibility [created by the authors]

\begin{tabular}{|l|l|}
\hline Accessibility (max - 12 points) \\
\hline Characteristic feature & Points - criteria \\
\hline Visual & $\begin{array}{l}\text { 3- The territory is visible and easy to see from the main street of the village; 2- The } \\
\text { territory is not visible from the main street of the village, but there is a visible sign on the } \\
\text { street, which guide to the place; 1- The territory is to be seen only in the immediate } \\
\text { vicinity. }\end{array}$ \\
\hline Physical & $\begin{array}{l}\text { 3- The area is easily accessed by both pedestrians and cyclists and by car. There is } \\
\text { connection to the main street of the village; 2- The area is easily accessed by both } \\
\text { pedestrians and cyclists and by car. There is no connection to the main street of the } \\
\text { village; 1- The area is accessible only to pedestrians and cyclists. It is impossible to drive } \\
\text { by car. There is no place for parking. }\end{array}$ \\
\hline Emotional & $\begin{array}{l}\text { 3- The area is freely available and inviting; 2- The territory is freely available only to a } \\
\text { specific group of people; 1- The territory is freely accessible but not encouraging or it is } \\
\text { unclear whether the territory is freely available or not. }\end{array}$ \\
\hline Universal accessibility & $\begin{array}{l}\text { 3- Available to everyone, it is multifunctional and thoughtful about all groups of society; } \\
\text { 2- The place is not accessible to people with disabilities but is accessible to other groups }\end{array}$ \\
\hline
\end{tabular}


Assessment of the quality and accessibility of public open space [created by the authors]

\begin{tabular}{|c|c|c|c|}
\hline \multirow{4}{*}{ 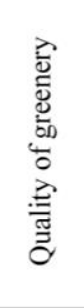 } & Assessment & Points & Valuation \\
\hline & LOW & $3-5$ & $\begin{array}{l}\text { The proportion of greenery in the area is less than } 1 / 4 \text { and mainly consists of a few } \\
\text { local plant species or broadly decorated plantations that do not harmonize with the } \\
\text { environment and landscape. }\end{array}$ \\
\hline & MEDIUM & $6-8$ & $\begin{array}{l}\text { Approximately half of the area is covered with greenery - a small variety of indigenous } \\
\text { plant species that form harmony with the environment and fits into the landscape. }\end{array}$ \\
\hline & GOOD & $9-10$ & $\begin{array}{l}\text { Most of the territory consists of greenery, plant species typical of the local area, or } \\
\text { skilled and successfully planed greenery. }\end{array}$ \\
\hline \multirow{3}{*}{ 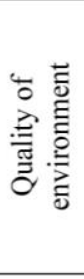 } & LOW & $5-7$ & $\begin{array}{l}\text { The environment is disordered and chaotic or even degraded, and therefore unsafe. It } \\
\text { has a potentially valuable landscape, scenic views, or cultural and historical elements } \\
\text { in it. But their presence in the territory is not visible and accentuated. }\end{array}$ \\
\hline & MEDIUM & $8-11$ & $\begin{array}{l}\text { The environment is clean and tidy, enjoyable, similar to the urban environment, thus } \\
\text { losing some of the identity of the coastal village. There are cultural and historical } \\
\text { elements in the territory, but they are not emphasized or highlighted. }\end{array}$ \\
\hline & GOOD & $12-15$ & $\begin{array}{l}\text { The environment is inherent or semi-natural, safe, landscape-rich, with the presence } \\
\text { of cultural and historical elements as main dominations in site. }\end{array}$ \\
\hline \multirow{3}{*}{ 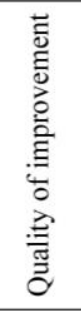 } & LOW & $4-7$ & $\begin{array}{l}\text { The territory is not well-developed, its functional zoning and infrastructure is not } \\
\text { organized. There is no consistent quality of the surface, as well as the design of the } \\
\text { outdoor elements. }\end{array}$ \\
\hline & MEDIUM & $8-9$ & $\begin{array}{l}\text { The area is partially landscaped with minimal, functional infrastructure. The quality } \\
\text { of surface is sufficient. Improvement elements and the design of the pavement are not } \\
\text { in harmony with the environment. }\end{array}$ \\
\hline & GOOD & $10-12$ & $\begin{array}{l}\text { The area is well-equipped with a convenient and well-organized infrastructure. The } \\
\text { quality of the surface is good and the design of the elements of the amenities is } \\
\text { harmonious and in harmony with the surrounding environment. }\end{array}$ \\
\hline \multirow{3}{*}{ 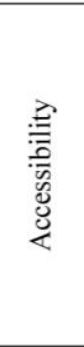 } & LOW & $4-6$ & $\begin{array}{l}\text { Place can be seen only when it is in close proximity and accessible only to pedestrians. } \\
\text { From the point of view of emotional perception, it is unclear whether it is freely } \\
\text { accessible, or restricted, and is only available to certain groups of the population. }\end{array}$ \\
\hline & MEDIUM & $7-9$ & $\begin{array}{l}\text { The place is not visible from the main village street, but there is a noticeable, attention- } \\
\text { grabbing reference to the place. There is a possibility that there is no convenient road } \\
\text { network connecting to the main village street. From a perceptive point of view, the } \\
\text { area is freely accessible but not encouraging. It is not accessible to people with } \\
\text { disabilities. }\end{array}$ \\
\hline & GOOD & $10-12$ & $\begin{array}{l}\text { The area is visible from the main village street and is accessible to all sections of the } \\
\text { community, whether on foot or by car or bicycle. It is freely available and inviting. }\end{array}$ \\
\hline
\end{tabular}

and location of residential areas, as well as the existing natural base, its values. As the most common types of public open spaces in Engure there are - open space at public buildings, infrastructure objects and areas of peaceful rest, nature areas.

\section{Quality}

In evaluating the quality of the public open space in the village, the low-quality assessment in Engure is in assessment of the sub-factors of the improvement and greenery, but the quality of the environment is assessed as medium. Analyzing the assessment matrix of Engure village (Table 4) and diagrams (Fig. 5), it is seen that the quality assessments of the greenery of each individual open space have split up into similar parts $-30 \%$ of the surveyed open spaces in Engure are evaluated with good and medium quality of greenery, but almost half $-40 \%$ low. The low greenery quality is rated for the following public open spaces: Southern Mall, the dock of the yacht port, market, and stadium. The assessment is considered to be partially appropriate, as the Southern Mall and the dock of the yacht port are considered to be industrial or infrastructure objects whose greenery is not essential first of all and does not affect the quality of the whole. On the other hand, the greenery located on the market, located in mobile boxes, is considered to be inappropriate (species selection), but around the stadium it would be advisable to place a group of protective greenery which would shelter territory from wind. Half of the surveyed public open spaces in Engure are of low quality, and only $20 \%$ of open spaces are considered to be of good quality. Such public open spaces as the parking lot near the church, the South Mole, the dock of the yacht port, the market, the area near the meeting house have low improvement quality.

The low assessment is the reason of the lack of elements of improvement in place to ensure the full and comfortable use of the place, as well as the poor quality of the condition of the surface and the design coherence for both the surface and the elements of the improvement.

In the environmental quality, $80 \%$ of the surveyed open space is rated as medium, which is assessed as well-tended and clean, but the potentially valuable elements of the place are not interfaced with it - hidden valuable landscape views or uncovered elements of cultural and historic significance in the village landscape. 


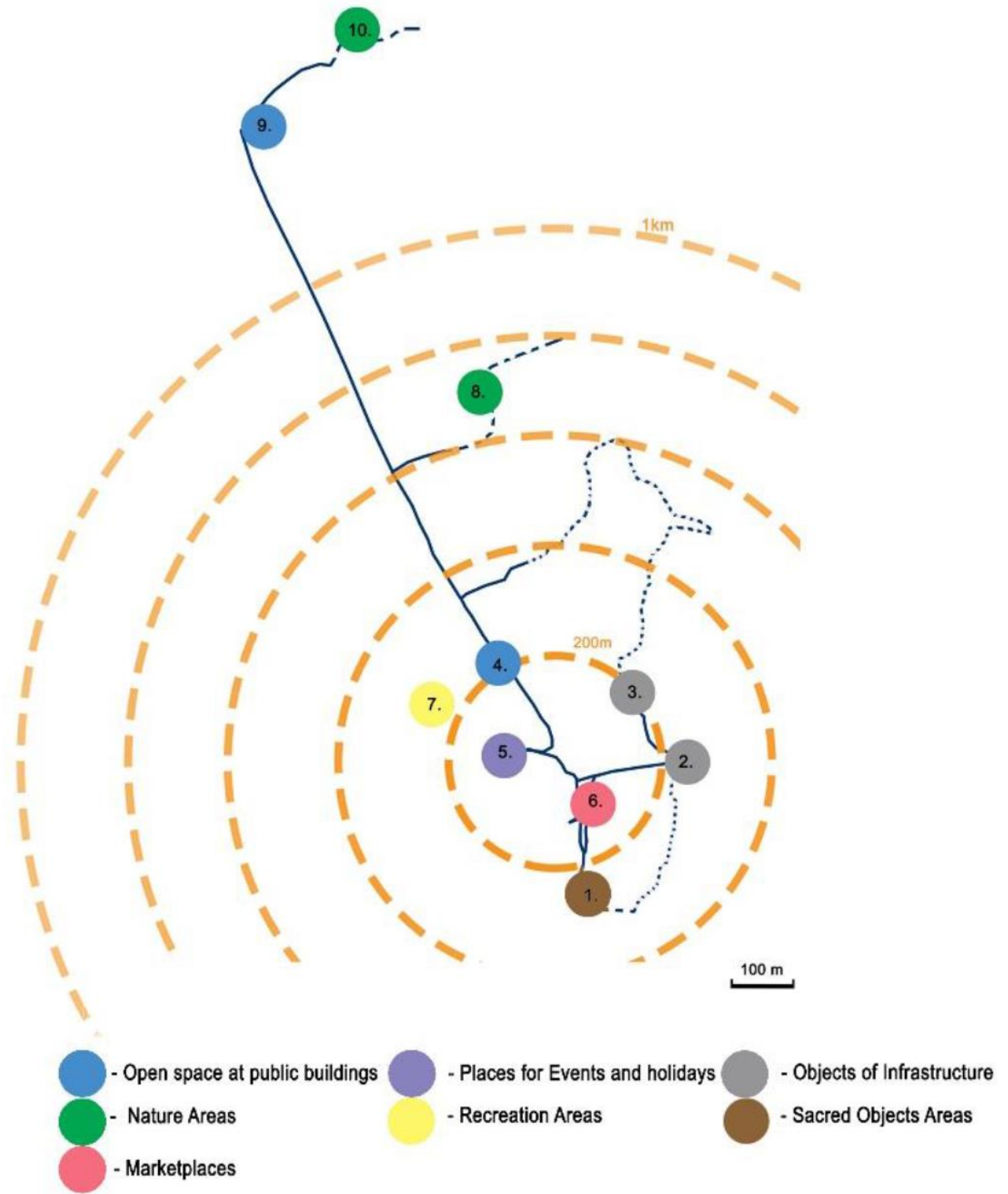

Fig. 4. Public opne space structure in engure [created by authors]

1 -Parking and church; 2 - Mole; 3 - Harbor; 4 -Square; 5 - Bandstand; 6-Market; 7 -Stadium; 8 / 10 - Hiking trail and beach; 9 - Meeting house

Assessment of the quality of public open space [created by the authors]

\begin{tabular}{|c|c|c|c|c|}
\hline & 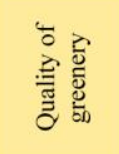 & 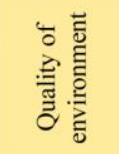 & 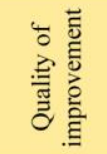 & 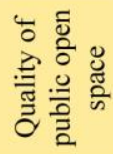 \\
\hline 1. Parking and church & medium & medium & low & medium \\
\hline 2. Mole & low & medium & low & low \\
\hline 3. Harbor & low & medium & low & low \\
\hline 4. Square & medium & medium & medium & medium \\
\hline 5. Bandstand & good & medium & medium & medium \\
\hline 6. Market & low & medium & low & low \\
\hline 7. Stadium & low & medium & medium & medium \\
\hline 8. Hiking trail and beach & good & good & good & good \\
\hline 9. Meeting house & medium & medium & low & medium \\
\hline 10. Hiking trail and beach & good & good & good & good \\
\hline
\end{tabular}




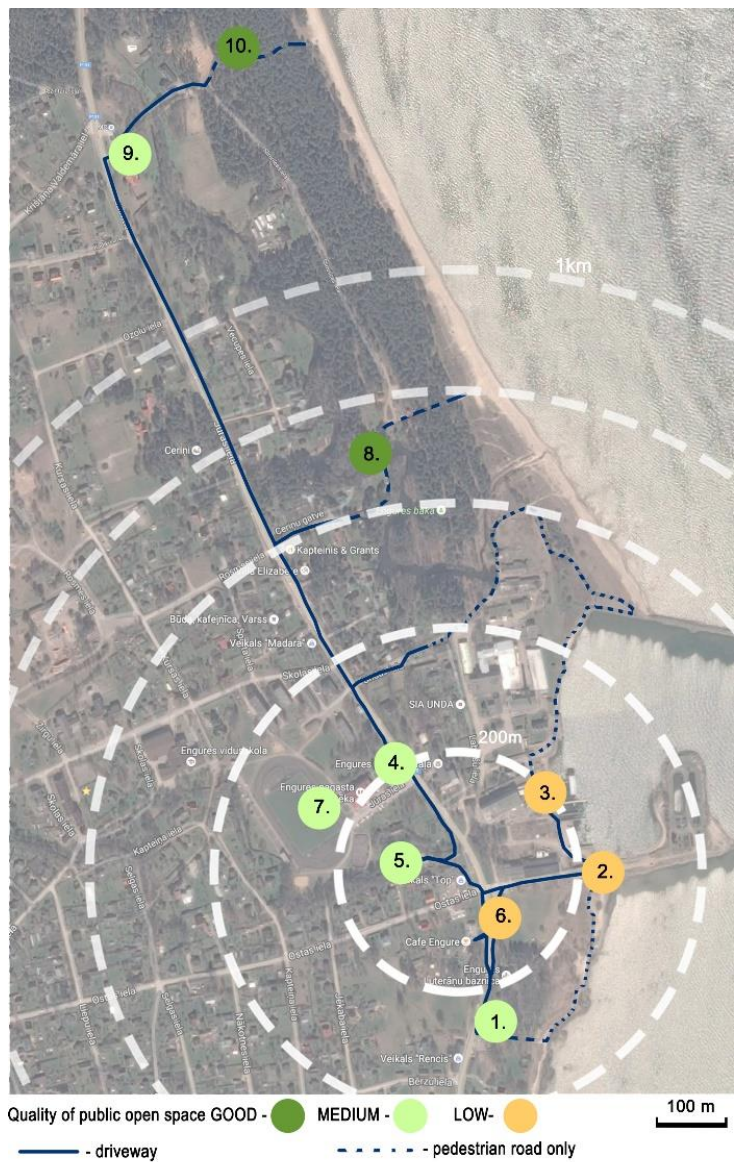

Fig. 5. Public open space quality diagrams [created by authors] 1 -Parking and church; 2 - Mole; 3 - Harbor; 4 - Square; 5 Bandstand; 6-Market; 7 -Stadium; 8 / 10 - Hiking trail and beach; 9 - Meeting house

TABLE 5

Assessment of the accessibility of public open space [created by the authors]

\begin{tabular}{|c|c|c|c|c|c|}
\hline & $\begin{array}{l}\overline{\underline{g}} \\
\overline{3} \\
\frac{3}{2}\end{array}$ & 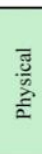 & 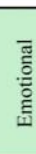 & 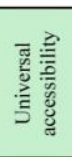 & 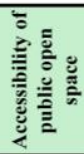 \\
\hline 1. Parking and church & 3 & 3 & 1 & 2 & medium \\
\hline 2. Mole & 1 & 3 & 1 & 2 & medium \\
\hline 3. Harbor & 1 & 3 & 1 & 2 & medium \\
\hline 4. Square & 3 & 3 & 3 & 3 & good \\
\hline 5. Bandstand & 2 & 1 & 3 & 1 & medium \\
\hline 6. Market & 3 & 3 & 3 & 3 & good \\
\hline 7. Stadium & 2 & 2 & 1 & 1 & low \\
\hline 8. Hiking trail and beach & 2 & 1 & 3 & 2 & medium \\
\hline 9. Meeting house & 3 & 3 & 2 & 2 & good \\
\hline 10. Hiking trail and beach & 2 & 3 & 3 & 2 & good \\
\hline
\end{tabular}

\section{Accessibility}

On evaluating the availability of the public open space of Engure village gained results shows that $80 \%$ of the universals, physical and visual availability of the surveyed open spaces are good or medium. The emotional approach has the lowest of accessibility rating / valuation. Half of the surveyed open spaces has an emotional a vailability of good,

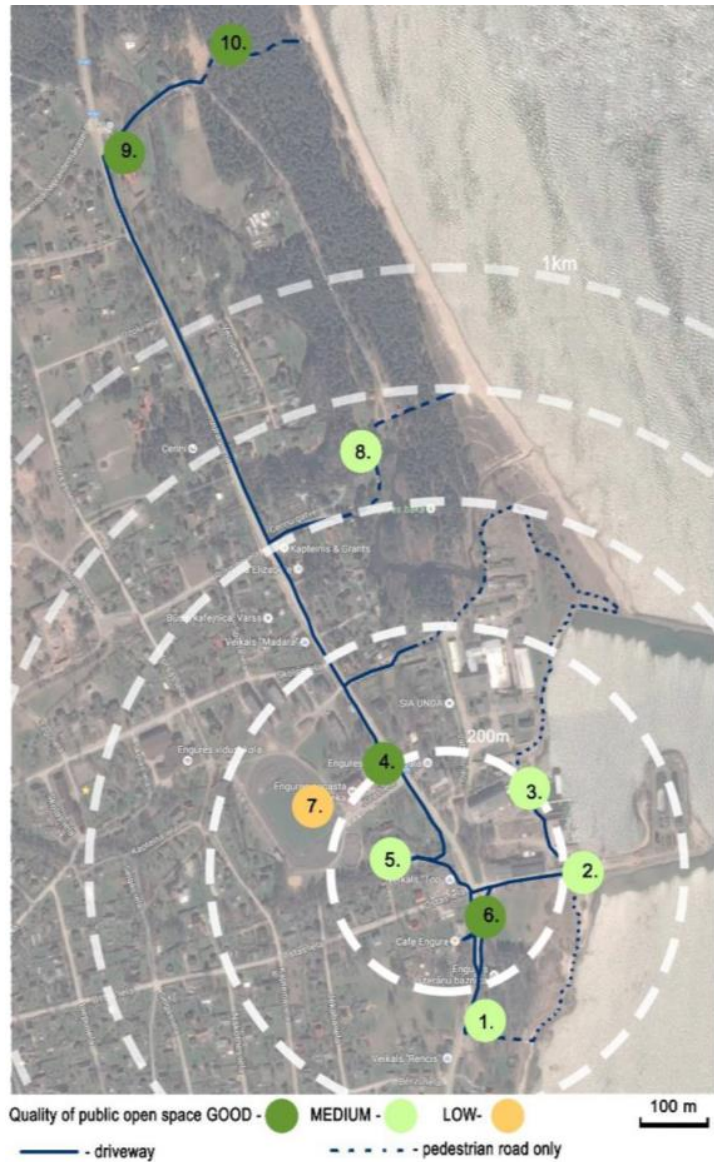

Fig. 6. Public open space accsesibility diagrams [created by the authors]

1 -Parking and church; 2 - Mole; 3 - Harbor; 4 - Square; 5 Bandstand; 6-Market; 7 -Stadium; 8 / 10 - Hiking trail and beach; 9 - Meeting house

$10 \%$ medium, but $40 \%$ of the open spaces is low, i.e. a parking lot near the church and the church area, the Southern Mall, the dock of the yacht port and the stadium. However, after the total number of points, these individual low values are offset by good values and, as it is seen in the availability matrix of Engure village (Table 5), and the mapping schema of the availability assessment (Fig. 5), that the low availability quality was obtained only for the stadium

The first three of the low ratings are because of the functional layout of the place or the elements of the improvement. Of course, the church is freely available to all inhabitants, but it is located behind a small fence and large gates - visually hardly noticeable, as large trees are grown around it, and without adequate fore and improvement, there is a feeling that it is better not to stay in this place and guests are not invited. Port territory is a private property and although the physical availability of moles and the port area is freely accessible, it is not clear whether this is allowed or not allowed to stay free of charge. Also, the visual accessibility of these two objects is considered low, because the place is 
almost invisible of the main village street. The sight of this is obscured by the industrial building of the port. Similarly, the quality of the surface of the stadium and the playing field is low - inappropriate for sporting activities, the only seats are arranged in the stands, the place is not accessible to people with special needs.

\section{Conclusion}

Researching the functionality and location structure of the public open space of Engure village there is a clearly defined central part of the village with public open spaces such as a port area, stage, square near a cultural house, stadium, and church area with a parking lot near the sea.

The quality of the public open space in Engure village is assessed as medium, with a tendency to poor quality of improvement and greenery, which would be prime improvement indicators to increase the overall quality of the public opens space in Engure village. On the other hand, the accessibility of the public open spaces of the village is considered good. Such an assessment is determined by the proximity of the public open spaces to the main street of the village, which ensures their availability or visibility. In cases where the open space is not located in immediate proximity to the street, signs of information indicate them.
Obtained results of the quality and accessibility assessment can be applied for purposeful management and maintenance of existing public open spaces. Based on assessments of quality, availability and functionality, cartographic and graphic materials as primary improving public open spaces in the village there are defined:

- Areas in the center of a village with low availability or quality rating.

- Areas of a village with a low availability or quality rating.

- Areas in the center of a village with a medium accessibility or quality rating.

- Areas of a village with a medium availability or quality rating.

Obtained results of the research can be applied in practice, planning work in local municipalities - in the arrangement of the public open spaces in populated areas. Detailed analyzing the evaluation matrix of each public open space and its results, understanding the reasons for the low evaluation and their possible solutions, which are divided into short-term and long-term works.

The obtained results of quality and accessibility, functionality assessment and graphical materials obtained as a result of analysis can be applied for purposeful management and maintenance of existing public spaces, planning of new public open spaces.

\section{References}

1. Briṇkis J., Buka O. Reǵionālā attīstība un prognostika pilsētplānošanas kontekstā. Rīga, 2008, 194 lpp.

2. Carr, S., Francis, M., Rivlin, L. G., \& Stone, A. M. Public space. Cambridge: Cambridge University Press, 1992, Vol. 40, $400 \mathrm{p}$.

3. Engures novada teritorijas plānojums (The spatial planning of the district of Engure) [online 15.01.2017.] http://www.enguresnovads.lv/uploads/filedir/terit_planojums/Paskaidrojuma_raksts.pdf

4. From the archive of the museum of Engure.

5. Gehl, J. Svarre, B. How to Study Public Life. Washington, DC: Island Press, 2013. 179 p.

6. Gehl, J., \& Gemzøe, L., Public Spaces, Public Life: Copenhagen. $3^{\text {rd }}$ ed. Copenhagen: Danish Architectural Press \& the Royal Danish Academy of Fine Arts, School of Architecture Publishers, 2004. 96 p.

7. Giles-Corti, B., Broomhall, M. H., Knuiman, et.at. Increasing Walking. How Important Is Distance To, Attractiveness, and Size of Public Open Space? American Journal of Preventive Medicine, 2005, Vol. 28, p. 169-176.

8. Herzele, A. Van, \& Wiedemann, T. A monitoring tool for the provision of accessible and attractive urban green spaces. Landscape and urban planning. Elsevier: 2003, Vol. 63, p 109-126. ISSN 0169-2046

9. Jalaladdini, S. Oktay, D. Urban Public Spaces and Vitality: A Socio-Spatial Analysis in the Streets of Cypriot Towns. Procedia - Social and Behavioral Sciences. Elsevier: 2012, Vol. 35, p. 664-674.

10. Kianicka, S., Buchecker, M., Hunziker, M., \& Müller-Böker, U. Locals' and tourists' sense of place: A case study of a Swiss Alpine village. Mountain Research and Development, 2006, No. 26 (1), p. 55-63.

11. Leng, H., \& Li, T. Research on Public Open Space of Rural Areas in Severe Cold Regions Based on Survey of Residents on the Behavioral Activity. Procedia Engineering. Elsevier: 2016, Vol. 146, p. 327-334.

12. Nasution, A. D., \& Zahrah, W. Community Perception on Public Open Space and Quality of Life in Medan, Indonesia. Procedia - Social and Behavioral Sciences. Elsevier: 2014, Vol. 153, p. 585-594.

13. Nitavska, N. The Baltic Sea coastal landscape identity in Latvia. Ph.D. thesis. Latvia University of Agriculture, 2014. 128 p.

14. Vadlīniju izstrāde apstādījumu struktūras un publisko ārtelpu tīklojuma nodrošināšanai Rīgā: (Development of the guidelines for the provision of greening structures and public open space networks in Riga) [online 20.10.2016.] http://www.sus.lv/sites/default/files/media/faili/ii_sejums_petijums_vadliniju_izstrade_apstadijumu_strukturas_un_p ublisko_artelpu_tiklojuma_nodrosinasanai_riga.pdf

15. Vispārīgie teritorijas plānošanas, izmantošanas un apbūves noteikumi (General spatial planning, use and building regulations) [online 17.11.2016.]. https://likumi.lv/doc.php?id=256866

16. What makes a successful place? [online] Project for public spaces [cited 20.10.2015.]. https://www.pps.org/reference/grplacefeat/ 
INFORMATION ABOUT AUTHORS:

Anna Kalniņa - Lector at Latvia University of Agriculture, Faculty of Environment and Civil Engineering, Department of Landscape architecture and Planning. E-mail: anna.kalnina@llu.lv

Natalija Nitavska - Asoc. professor at Latvia University of Agriculture, Faculty of Environment and Civil Engineering, Department of Landscape architecture and Planning. E-mail: natalija.nitavska@1lu.lv

Kopsavilkums. Pasaulē publiskās ārtelpas loma un nozīme pilsētu un apdzīvoto vietu kontekstā aizvien pieaug un kḷūst nozīmīga gan saistīto jomu profesionāḷu, gan iedzīvotāju vidū. Arī Latvijā šīs tēmas aktualitāte pēdējo gadu laikā ir palielinājusies. Publiskā ārtelpa ir viens no nozīmīgākajiem dzīves vides kvalitātes raksturojošajiem aspektiem, kas ietekmē vietas ekonomiskos un sociologiskos faktorus. Publiskās ārtelpas kvalitāte vērtējama kā svarīgs urbānās vides faktors, jo pati publiskā ārtelpa ir viens no šīs vides ainavas struktūras galvenajiem pamatelementiem, kas var būt nozīmīgs ietekmējošais faktors, lai veicinātu iedzīvotāju atgriešanos lauku rajonu ciemos un pilsētās. Tā veido vietas identitāti un raksturo sabiedrību, kas to veido un tajā uzturas. Pētījumā vērtēta Engures ciema publiskās ārtelpas. Engures ciems ir viens no Latvijas piekrastes zvejniekciemiem, kas veidojies 13. gs. 2. pusē, vēlāk attīstoties kā viens no mazo ostu ciemiem Rīgas jūras līča rietumu piekrastē. Engurē dzīvo ap 1500 iedzīvotāju, bet vasaras sezonā ciems kḷūst par iecienītu tūristu un atpūtnieku galamērḳi. Piekrastes ainava un vēsturiski veidojusies kultūrvide raksturo ne tikai Engures ciematu, un tās publisko ārtelpu, bet arī Latvijas piekrastes ainavas un vides identitāti. Tā ir tautas tradīciju un vēsturisku notikumu bagāta ainava ar piekrastes zvejniekciemiem un mazām pilsētām, kas 19. un 20. gadsimtā veidojās kā ekonomiski attīstītākās piekrastes vietas, šodien kḷuvušas par neatṇemamu piekrastes ainavas elementu un nozīmīgu apdzìvoto vietu struktūras sastāvdaḷu ilgtspējīgai valsts attīstībai. Vietas dabas un kultūrvēsturiskās vērtības, ǵeogrāfiskais novietojums un kultūras mantojums ar tautas tradīcijām, Enguri veido kā potenciālu brīvdienu atpūtas vai dzīves vietas galamērķi. Pētījumā izmantojot salīdzinošo metodi zinātniskās literatūras analīzei, tika noteikti publiskās ārtelpas veidojošie pamatfaktori un atlasīti pamatkritēriji ārtelpas kvalitātes, pieejamības un funkcionalitātes novērtējumam. Veicot ciema publisko ārtelpu novērtējumu, iegūtie rezultāti atspoguḷo Engures ciema publiskās ārtelpas kvalitāti, kuru raksturo vietas pieejamība, labiekārtojuma, apstādījumu un vides kvalitātes kopvērtējums. Iegūtos kvalitātes un pieejamības, funkcionalitātes novērtējuma rezultātus un analīzes rezultātā iegūtos grafiskos materiālus, iespējams pielietot mērķtiecīgai esošo publisko ārtelpu apsaimniekošanai un uzturēšanai, jaunu publisko ārtelpu plānošanai. Balstoties uz kvalitātes, pieejamības un funkcionalitātes novērtējumiem, kartoshēmām un grafiskajiem materiāliem iespējams definēt primāri uzlabojamās. 


\title{
The industrial heritage around the coast of the Baltic sea at Pāvilosta municipality
}

\author{
Dace Ržepicka, Aija Ziemeḷniece, Una Īle, Latvia University of Agriculture
}

\begin{abstract}
Today, in the coastal area of the municipality of Pāvilosta, preservable natural riches meet - the seashore bluff of the Baltic Sea, the nature reserves "Ziemupe", "Gray Dune", the old and still living craft of the fishery of the inhabitants of the coastal region. The values of the industrial heritage of the end of the $19^{\text {th }}$ century are readable - the jetties, Pāvilosta, the lighthouse of Akmeṇrags, chimneys of kilns, farm buildings at Upesmuiža, which presently create the opportunities for prospective management and development of the society. The historical experience and the technological requirements of the management of the $21^{\text {st }}$ century affect the existing cultural landscape and motivate the perspective of development.

This is attributable to tourism and the trend of searches for the living space in the municipality of Pāvilosta, proving that this location has the uniqueness of the ecological core and identity of the location. The fishery sector at Pāvilosta is strengthened by the newly built fishing quay and the modern marinas on the right and the left bank of the river Saka, reconstruction works of the jetties and the lighthouses. In renovating the existing building or constructing new buildings, there is an expressed tendency to maintain the scale of the building volume, coloring, and texture of building materials that promote the historic and the new spatial harmony. The lighthouse of Akmeñrags, which creates a pronounced dominant in the landscape, has become a favorite tourist destination.

Keywords: cultural and historical landscape, industrial heritage, building scale, coloring, texture
\end{abstract}

\section{Introduction}

Through researching the landscape space of the industrial heritage in the municipality of Pāvilosta along the coastline of the Baltic Sea, the five kilometers wide coastline is surveyed, according to the Protection Zone Law [8] and the available histories and archive data are compared with the existing natural situation on the site typology and the current situation. In the municipality of Pāvilosta, the industrial heritage of the coastal zone consists of factories and household structures of the former manor estates, as well as fishery and shipping facilities, lighthouses, road building, and bridges. The industrial heritage also includes the narrowgauge railway and the station built at the start of the $20^{\text {th }}$ century. The most significant industrial heritage focuses at Pāvilosta with the port founded in 1879. The boom began with the construction of Liepāja Karaosta and the opportunity to transport thither both stones and agricultural production. At the start of the 1920s, fishery, shipping, shipbuilding, and trading have already been developed at Pāvilosta.

The most remarkable sites of the industrial heritage in the municipality of Pāvilosta have survived since the start of the $70 \mathrm{~s}-80 \mathrm{~s}$ of the $19^{\text {th }}$ century and the start of the $20^{\text {th }}$ century. After the war in the $50 \mathrm{~s}-80 \mathrm{~s}$ of the $20^{\text {th }}$ century, the life of the coastal people was rapidly changing, the number of the population was reduced by war and deportations which was facilitated by the presence of the army and the coastal isolation. The individual fishing collapsed, fishery gear and attributes disappeared, such as stakes, plank-ways, and trestles, railway installations were eliminated [9]. The manor outbuildings have disappeared, the remaining ones are often exposed to a rough rebuilding without architectural understanding. In turn, at the estuary of the river Saka at Pāvilosta the port reconstruction works are in progress and there is a boom in the sector of tourism and fishery. It is important not only to transform and regenerate but also to maintain the material evidence of the town's economic and cultural growth in the form of industrial sites. The provision of this goal will depend not only on the economic development in the early $21^{\text {st }}$ century but also from the political and economic power and the desire to recognize and appreciate the most significant historical stages of urban growth [11].

Not only the coastal economic and historical circulation and building but also the ecological core form a very strong context for the perception of the identity of the site. It is created by silhouettes and compositional elements which are made up of landscape horizontals and verticals on the coast masts of ships and yachts, lighthouses, windmills. The unique sight points from the seashore bluff and the manor houses ranked there, as well as the oldest parts of Pāvilosta, are an unrivaled treasure of the municipality and the heritage to be protected. The rapid disappearance of the small train mazbānītis, the ancient fishery, drying of nets and fish smoking have disappeared from the landscape and only the intangible cultural heritage has survived.

The aim of the research is to assess the context of the landscape space and the industrial heritage of the municipality of Pāvilosta lying on the coastal area of the Baltic Sea. A number of assignments have been moved forward for the research, namely, to: 
- Identify the diversity of the industrial heritage sites in the area under the study;

- Assess the landscape space of the industrial heritage of Pāvilosta in two sections of the coastal area - research of the scale of the industrial sites and the differences in the building density;

- The spatial aspects of the green structure;

- The coastal brownfield sites and causes.

\section{Materials and Methods}

The industrial site as a spatial nucleus of the economic activity affects the form creation of the landscape. The different types of economic functions have determined the historical locations of transport and pedestrian streams. The industrial environment expresses the spatial identity and increases recognition of certain places. The industrial landscapes of the coastal area of the Baltic Sea from Kolka to Pape are found both in the urban environment and in the landscape of the countryside. The heritage of the industrial environment is readable both through the material and the intangible heritage. Many sites and landscape spaces around them have disappeared and the evidence can only be found in archival documents.

The concept of the industrial heritage as a concept of the cultural and the historical heritage is reflected in the regulations adopted by the Cabinet of Ministers. "The field of cultural heritage in the European practice covers the protection of immovable and movable cultural monuments and the identification, research, recording, preservation, use, and involvement of the cultural and historical heritage in the circulation of modern life. The cultural heritage of this program consists of:

- The architectural heritage;

- The archaeological heritage;

- The monumental, sacred, and applied art heritage;

- The industrial heritage;

- The underwater heritage [7]

- The Latvian Industrial Heritage Fund (LIH Fund) has developed the following typology of the industrial heritage:

- Production plants - factories, kilns, breweries, dryers, warehouses, workers' dwelling houses, separate production-related items (machine tools, equipment, boats, etc.), etc.;

- Bridges - street and rail bridges, viaducts, ferries, etc.;

- Railway installations - railway lines, stations, etc.;

- Lighthouses, pilot houses, and towers;

- Hydrotechnical structures - jetties, dams, canals, etc.;

- Road construction and signs - road sections, postal stations, etc.;
- Urban objects - fire stations, postal buildings;

- Water supply objects - wells, water towers, water pumps, water supply pumping stations, etc.;

- Electrical installations;

- Mills - watermills, windmills;

- Military installations - fortresses, fortifications, cannons, etc..

- The areas in which the sites of the cultural heritage are available have significant benefits for attracting tourists. The economic benefits of the tourism infrastructure - jobs, markets for goods and services, and the resulting taxes in the State and local government budgets depend on a number of factors - not only on the cultural heritage. The existence or absence of the cultural heritage determines the tourism potential of the area concerned. As the cultural sector is an important employer, there is a clear link between culture and the economic policy at the regional, national, and the European level [10].

In the research, the importance of the waterfront adjacent to the industrial heritage sites along the Baltic Sea coast is studied, including river estuaries and river sections. These are locations that historically provided transport links with production sites but nowadays the landscape environment is their value. The old production areas have the potential for the creation of industrial parks and the boom of tourism. The areas under development and the sites should consider the protected areas along the remarkable natural sites of the municipality of Pāvilosta - the seashore bluff of the Baltic Sea, which has recently been subject to severe erosions, Pāvilosta "Gray Dune", the Nature Reserve "Ziemupe".

While studying the landscape space of the industrial heritage in the coastal area of the Baltic Sea within the municipality of Pāvilosta, its 2 sectors have been surveyed:

1) The area research sector $A$.

The former manor areas of the parish of Saka - Labrags Manor, Ulmale Manor, Strante Manor, the seashore bluff Ulmale-Strante, and Akmenrags.

2) The area research sector $B$.

The town of Pavilosta and the historic factories at Upesmuiža near the steep bank of the river Saka.

Several methods have been used for the research:

- The comparative analysis - the study of the dynamics of development of the area, based on the analysis of historical materials and the comparison of the current situation, as well as the analysis of processes in certain periods;

- The complex method, by synthesizing the scenic, cultural environment, economic, architectural and spatial aspects; 
- The landscape identity model, the method of the visual, historical, cognitive element recognition;

- The study of literature, spatial development plans, archival materials.

\section{Results and Discussion}

The survey of the area research sector $\mathbf{A}$ shows that the boundaries of the historical areas of the former manors have not survived, as the land of the manors was distributed already in the 1990s to the new owners who have created a new landscape space during the past hundred years. Some of the areas of the former manors have been overgrown by trees or a landscape space of a new scale has been created, and, therefore, it is visually difficult to perceive the historical landscape as a compositionally uniform one. The old building of the manor has been preserved in part. The outbuildings and the production buildings have changed their function several times, they can be rebuilt or incorporated into a new building, thus losing the original scale.

Through researching the archival materials, the transformation of the coastal landscape space is well readable. This also applies to the vertical accent that has disappeared from Labrags Mansion - the chimneys of the brick kiln on the seashore bluff at the mouth of the river Riva. In recent years, the seashore bluff has undergone considerable erosions, exposing clay layers and promoting their slipping into the sea. As an industrial heritage site, the recently renovated wooden bridge across the river is the only wooden stanchion bridge in Latvia. In turn, the wool carding of Labrags Manor has disappeared, but the manor mill has survived.

The houses of Ulmale Manor were destroyed during World War I by the firing of the ships. The outbuilding, a long single-storied boulder building, located on the edge of the Ventspils - Liepāja highway, have survived. Only the oak alley ingrown in a meadow which extends from the highway to the side of the sea evidences that once Strante Manor was located there. In this section of the seashore bluff, the cultural and historical landscape consists of maritime meadows and shimmering waves on the horizon.

In the coastal research section, the most important site of the industrial heritage is the red brick lighthouse of Akmeñrags and its complex of houses at the seashore. The seashore bluff of Ulmale - Strante is the highest one in Latvia and reaches even $22 \mathrm{~m}$ in height, though exposed to the effects of nature, it is often affected by erosion. The beach at this location is very narrow. At the top, the landscapes of the flat meadows allow you to watch the sea and the wide surroundings through plains interpenetrating with the sea.

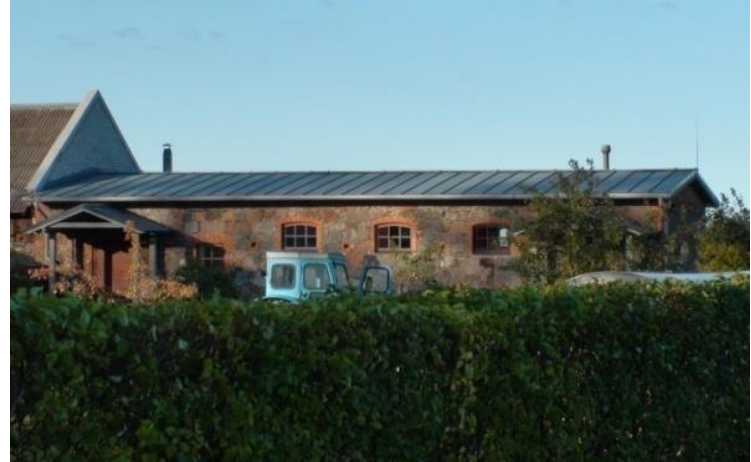

Fig. 1. The granary of Ulmale Manor [photo by the authors, 2017]

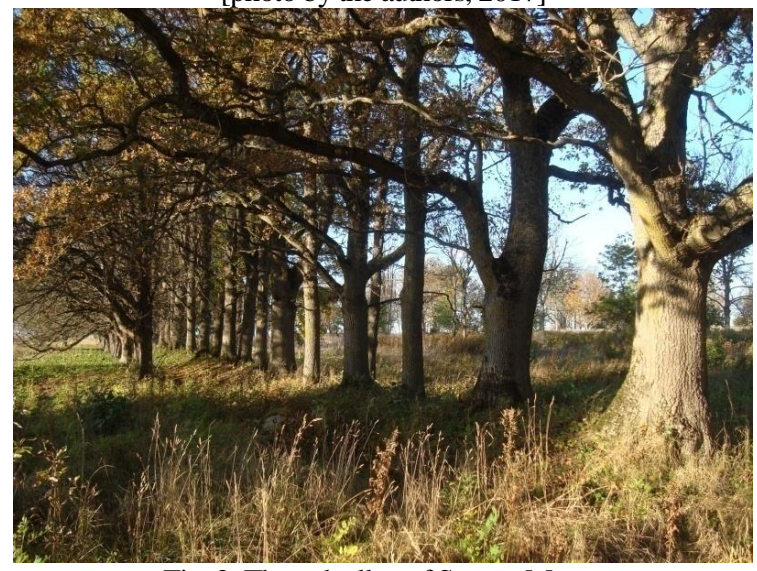

Fig. 2. The oak alley of Strante Manor [photo by the authors, 2017]

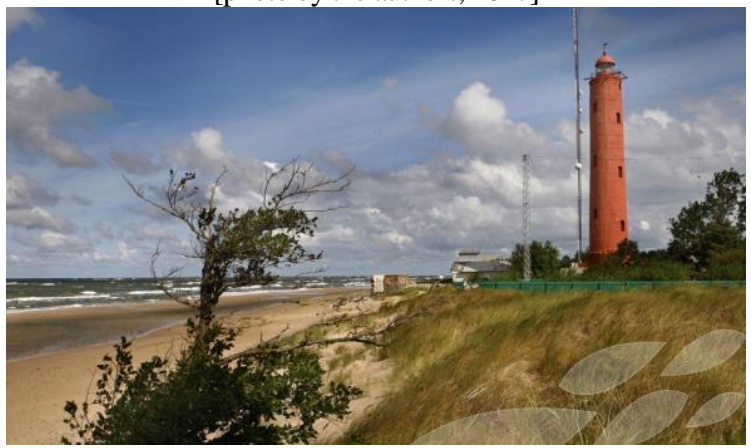

Fig. 3. The lighthouse of Akmenrags

[https://www.google.lv/search?q=

https://www.google.lv/search?q=labrags\&client=firefox-b$\mathrm{ab} \& \mathrm{dcr}=0 \& \mathrm{tbm}=$ isch\&sou]

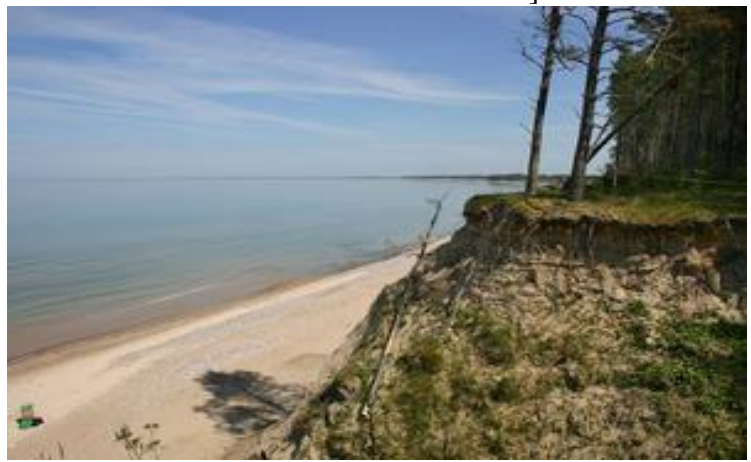

Fig.4 .The seashore bluff of Labrags [https://www.google.lv/search?q=

https://www.google.lv/search?q=labrags\&client=firefox-b$a b \& d c r=0 \&$ tbm $=$ isch\&sou] 


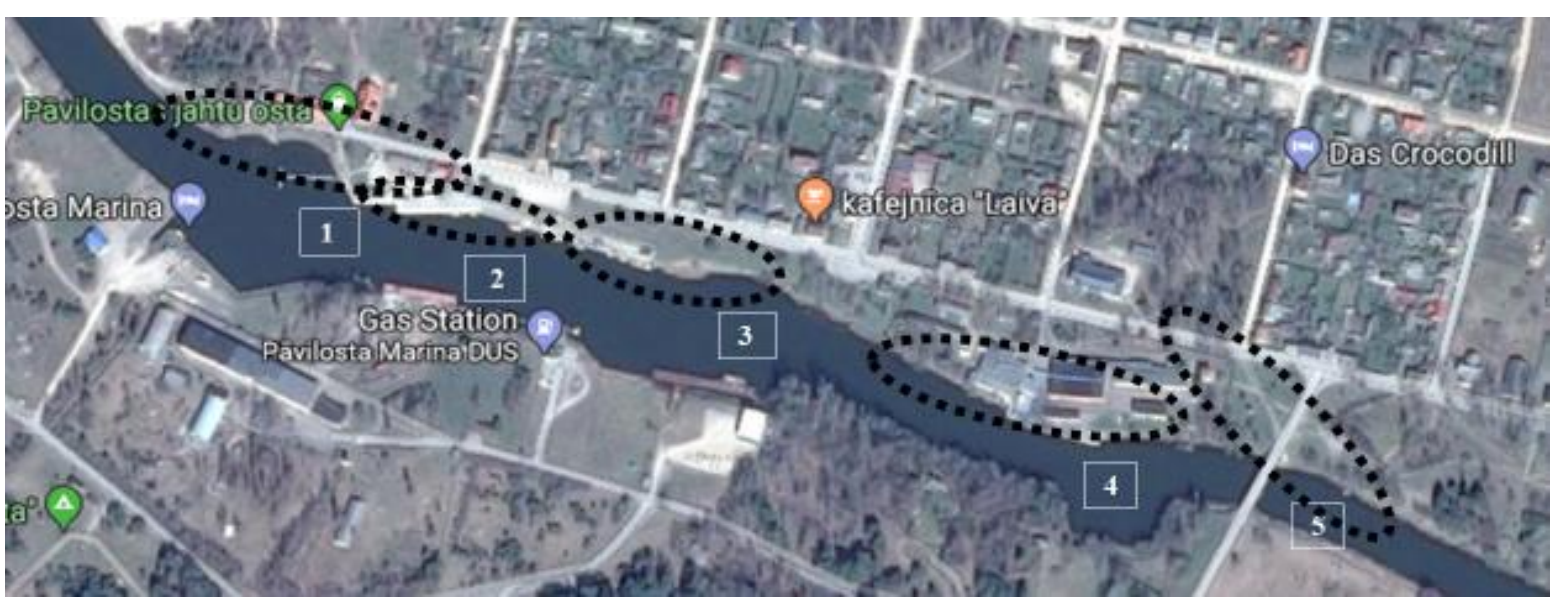

Fig. 5. The study of the landscape spaces of the right bank of the river Saka [created by authors]

Research of the coastal area in the sector B considers the sites of the industrial heritage at Pāvilosta and $3 \mathrm{~km}$ away - in the area of the former manor at Upesciems (Sackenhausen).

As it is already said, during the period from the 1970s until nowadays, the coastal area around Pāvilosta has experienced a number of booms phases. The other strong point of development of Pāvilosta was the adjacent Upesmuiža and its agricultural output, the sale of bricks and alcohol, which provided a rapid development of Pāvilosta and the manor estate. It was also contributed by the fact that the development of both Pāvilosta and the manor estate was encouraged by two enterprising brothers Paul and Otto von Lilienfeld.

Pāvilosta as a shipyard site and the provider of trade routes, in the prewar years, began to build the infrastructure of a small residential area with a street network of the village. Unfortunately, the two world wars and the Soviet occupation of the $20^{\text {th }}$ century have destroyed both the cultural and historical heritage and the importance of the port. Only the last 20 years have brought tourism attraction and the protection of the ecological core for maintaining and understanding the identity of the site.

At Pāvilosta, the river Saka as the "blue spine" and its green banks build not only an economically important artery but also determine the expressiveness and picturesqueness of Pāvilosta. It may be well readable from Dzintaru street which leads the newcomer into the city along the river bank to the sea. The parallelism of the street side-by-side to the bank of the river Saka, approximately $1 \mathrm{~km}$ in length gives the town a sense of the sea coming into the historical part of the building. The parallelism of Dzintaru street creates several landscape spaces for the right bank of the river Saka.

The jetty area, dominated by the context of the sea, the jetty, and the beach:

1. The flat bank line of the river and the perception of the historic building area (60 $\mathrm{m}$ in length);
2. The fishing quay area with a narrow floodplain meadow lane (the former marina where fishermen had built a fishing net hut) alongside the low-rise building on Dzintaru street $(150 \mathrm{~m})$;

3. A dense cover with an enclosed production area, blocking the sight lines to the banks of the river Saka in two separate segments $(60 \mathrm{~m})$;

4. The park area along the river up to the building of the 1970s (200 m);

5. The zone context with the forest landscape of the left bank of the river Saka.

Each of the above zones brings a different compositional character to the town. The first 3 areas that lay close to the sea are the most colorful and different in scale, building density, and architectonic stylistics. In studying the area in detail, the level of the visual and aesthetic quality of each one is described. The sight lines from Dzintaru street to the river Saka (from Vilınu to Tirgus street $150 \mathrm{~m}$ ) are the most expressive as they are open and not hidden by buildings or woody plant species. This is the historic berth on the banks of the river Saka with stakes, net trestles, net huts, boat plank-ways gone - nowadays it is a flat, green meadow.

In this area, the sight lines are long, and their deep plan features a readable forest landscape of the opposite bank of the river, complemented by a romantic mood with a marina. In turn, the right bank of $150 \mathrm{~m}$ in length serves for a fishing boat quay, so forming an impressive silhouette. The mentioned mooring lane on both sides of the river is visually changing with the seasons. A load of summer tourism turns the banks of the river into a dense marina. In the silhouette, the yacht masts attenuate the building of neighboring warehouse buildings on the left bank of the river. In turn, in the other seasons, with the decline of tourism, the industrial atmosphere prevails in the silhouette.

From Viḷnu street to Vitolu street, the sight points on the river $(80 \mathrm{~m})$ are completely hidden by warehouses and shrub rows which are opposite to the openness of the river previously examined. 


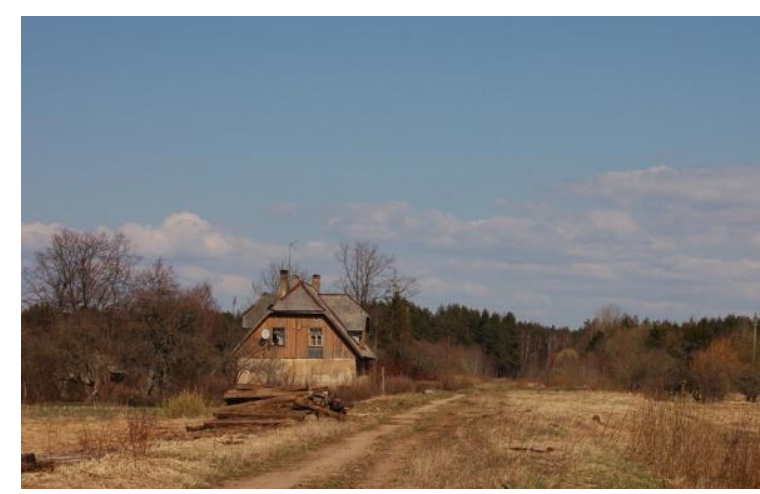

Fig. 6. Kursa Station and the dismantled rail path [http://www.parovoz.com/newgallery/?ID $=316943 \&$ LNG=RU\#picture $]$

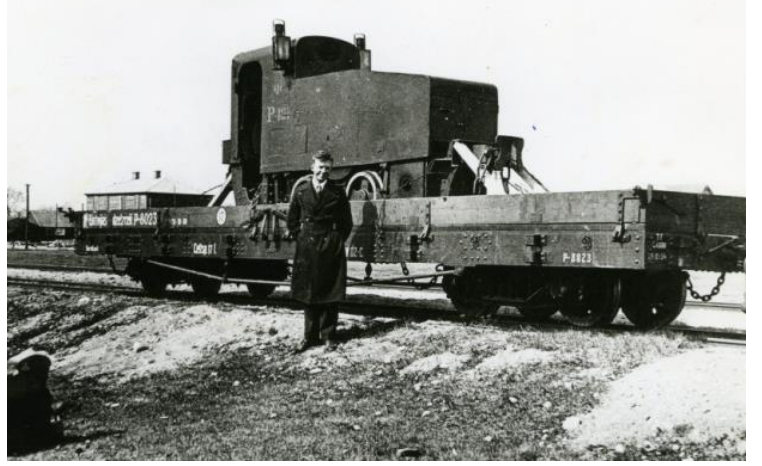

Fig. 7. Old rails at Pavilosta [9]

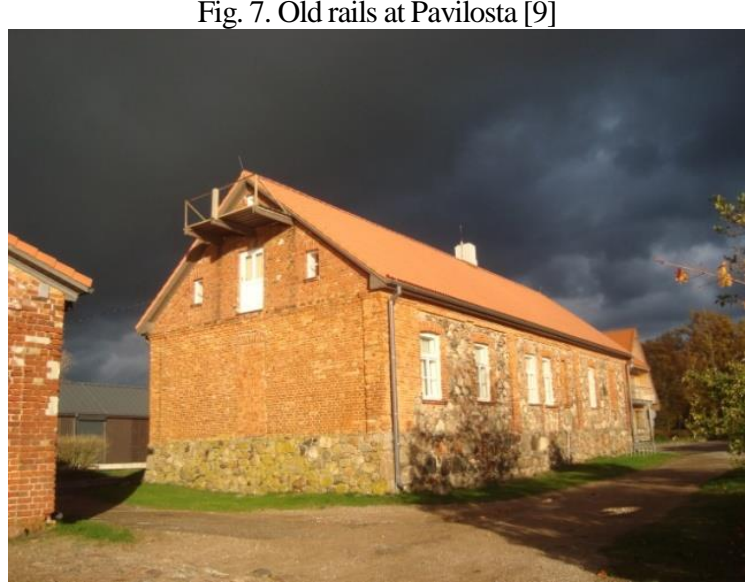

Fig. 8. The former pilot house [photo by the authors, 2017]

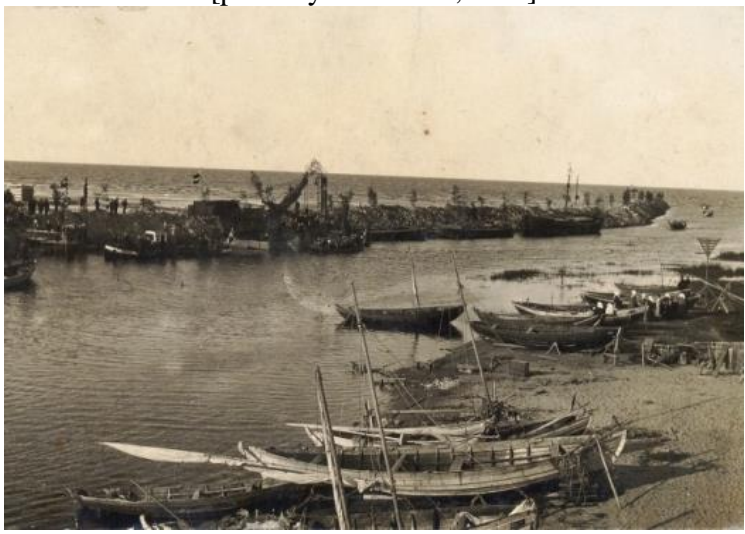

Fig. 9. The quay zone of the left bank of the river Saka in the 1920s [9]
The continuous housing creates a markedly industrial end of Dzintaru street near the former pilot house where the dune zone and the exit to the sea jetty begin. Opposite the dunes, on the left bank of the river in the 1970s, an exaggerated production building has been constructed in the proportion that drowns the expression of the bank. The arrival of vessels to the river Saka is provided by the old stone-stacking jetties with two lighthouses, where their reconstruction works have begun.

Similarly, there are a number of sight lines between Tirgus street and Kalna street in a $150 \mathrm{~m}$ long area enclosed with hedges and overgrown shrub groups. This is where the steep bank of the river begins, the expressiveness of which is not even noticeable. In this street section, alongside the shore, there is a construction area of the production site, which is surrounded by a high fence, which, together with the trees, forms an exaggerated scale and disrupts the compositional integrity of Dzintaru street.

Along with Kalna street, the two parkland areas begin, which locating on both sides of Dzintaru street, form a peculiar green gate before entering the historical center of the town. When comparing the archive's photo-capture, it's evident that a hundred years ago Baznīckalns has been a dune without trees around. Currently, the dune is covered by a large number of trees, forming separate groups of glades.

The southern side of Dzintaru street connects to the bank of the river, while the northern edge is connected with the small streets of Old Pavilosta with its mansions and the gardens, which end in the Gray Dune. It is a compositional peculiarity of the building of Pavilosta where the urban space is enclosed in the elements of the ecological core between the Gray Dune Lane and the bank of the river Saka. In turn, the "canvas network" of the streets contains both ecological cores together. The narrow-gauge train that was connected to the Ventspils-Liepaja and Alsunga line has contributed to a very strong growth of Pāvilosta. Transportation of the domestic agricultural products, lumber, boulders, brick to ports accounted for a good contribution to the coastal economic development. The economic prosperity was destroyed by the two world wars and the period of the Soviet occupation. The consequences of that led to the dismantling of the train paths in the 1990s. The same applies to the entry of barges at Pāvilosta. The archive photo materials brightly reflect the area of the giant glade near Dzintaru street until the war. Currently, the site of the former glade is occupied by a meadow and a cover of woody plant species. By the disappearance of the rail and the load of the maritime transport, Pāvilosta as a powerful production point with an ice-free port is gone. 


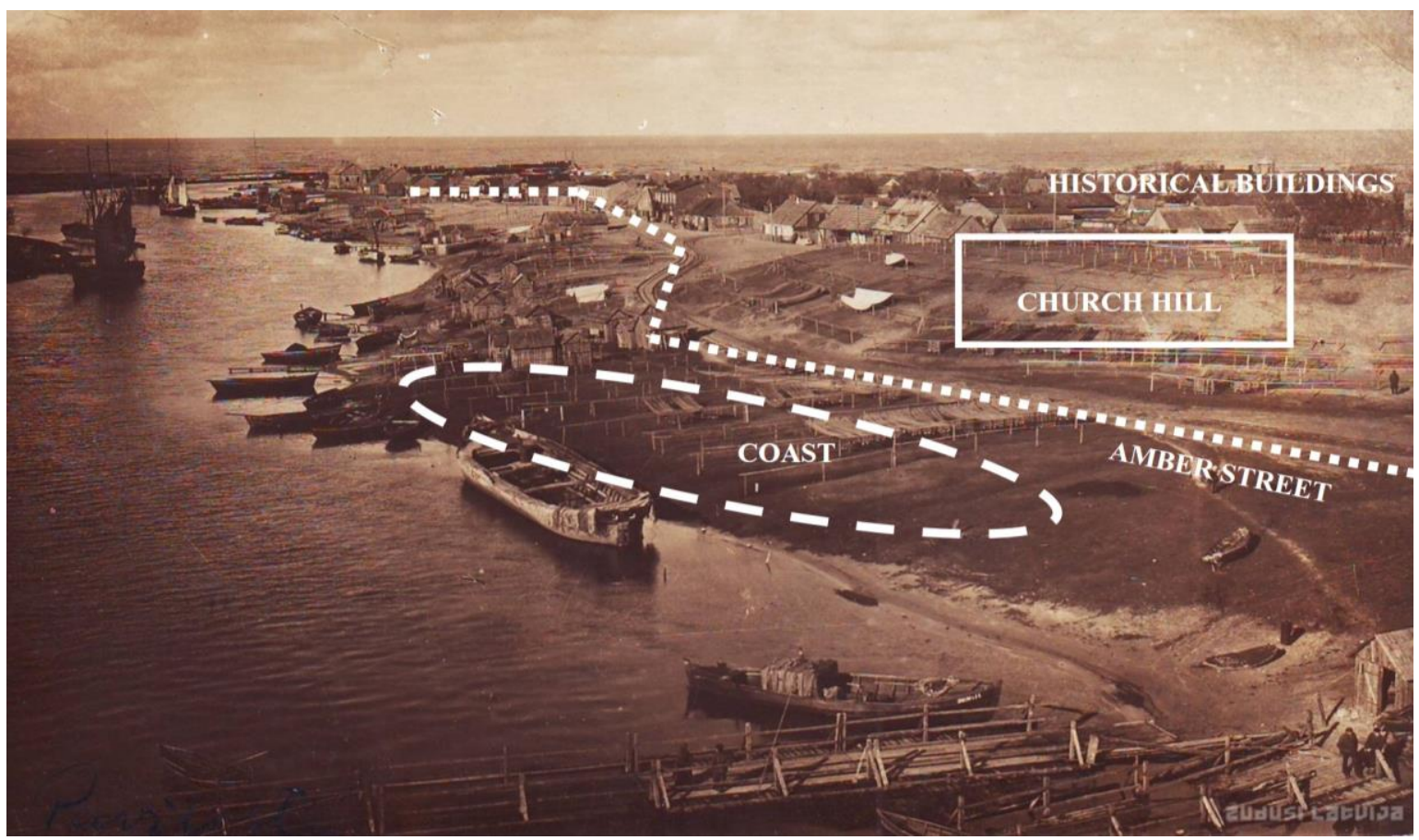

Fig. 10. The right bank of the river Saka with a glade near Dzintaru street, Baznīckalns, and the fishermen village, 1920 [created by the authors; 6]

Upstream the river Saka, in the distance of manor building on the eastern side, the old windmill approximately $2 \mathrm{~km}$ from Pāvilosta - the industrial heritage of the marine landscape is continued by Upesmuiža (Sackenhausen - the property of Baron von Zaken). Its development dates back to the turn of the $19^{\text {th }}$ and $20^{\text {th }}$ century, locating near the former Apriku road beside the flow of the Minde brook into the river Saka. The industrial production of the manor estate was provided by several strong aspects of the ecological core and the infrastructure:

1) The dirt road to Liepāja.

2) The rail from Alsunga to Liepāja.

3) The navigable river Saka with a passage to the sea;

4) Land fertility (fields, meadows);

5) Clay deposits.

The above values of the ecological core provided the construction of several production buildings - the windmill, brick kiln, and distillery. For the storage of the finished products, a granary, barn, cellar were built. Opposite the kiln over the river Saka, there was a raft bridge. Clay mine beds around the brick kiln are also visible today, creating separate pools. Considering the economic situation, a hundred years ago, the production volume of the manor was incredibly high. The field and meadow areas on both banks of the river Saka (see the old map) give evidence of the fertility of the soil. In the today's situation, part of the manor building, the so-called manor house (1905) is gone. The historic distillery and brick kiln building, built in the red brick architectural stylistics of the late $19^{\text {th }}$ century have survived. The old servants' house of the manor is also inhabited. In turn, away from the center of the has survived [12]. At Upesmuiža, the confluence of the river Tebra and the river Durbe, as well as the flow of the Mindes brook represented a very important support point for the agricultural development. Upstream the river Saka, a railway bridge over the river Saka has survived.

Today, both the historic dirt road from the manor to Apriki and the rail path to Alsunga are gone. Clay mines like giant pools, which stood at roadsides, are now noticeable in the middle of the fields, since in the postwar years under the effects of drainage agricultural areas developed. After the agrarian land reform in the 1920s, the land of the manor estate was split to build new farms with apple orchards instead of manor fields and meadow areas. The dairy built in the 1930s at the roadside from the estate to Apriki has also disappeared.

The modern rural industrial farming has disrupted the scale of the historic rural mosaic-like landscape.

The river Saka has served as a trade route to the exit to the sea. Historically, it has been referred to in the descriptions as the Saka port, which was located around $5 \mathrm{~km}$ up from Pāvilosta. The name of Saka was first mentioned in 1230. From the second half of the $13^{\text {th }}$ century up to the Livonian war, Saka is a property of the bishops, who have repeatedly feuded it. In the $15^{\text {th }}-18^{\text {th }}$ century, Saka is managed by the Osten-Sacken family. At the start of the river Saka (the point of confluence of the river Tebra and the river Durbe), there was the center of Saka (Saceze) with the Kursu and Bruninieku mounds, 


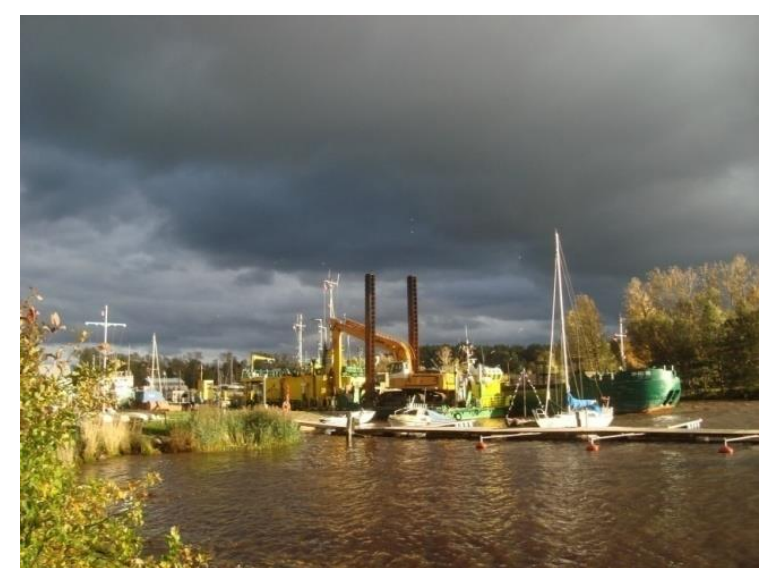

Fig. 11. A modern port with a marina [photo by A. Ziemelniece, 2017]

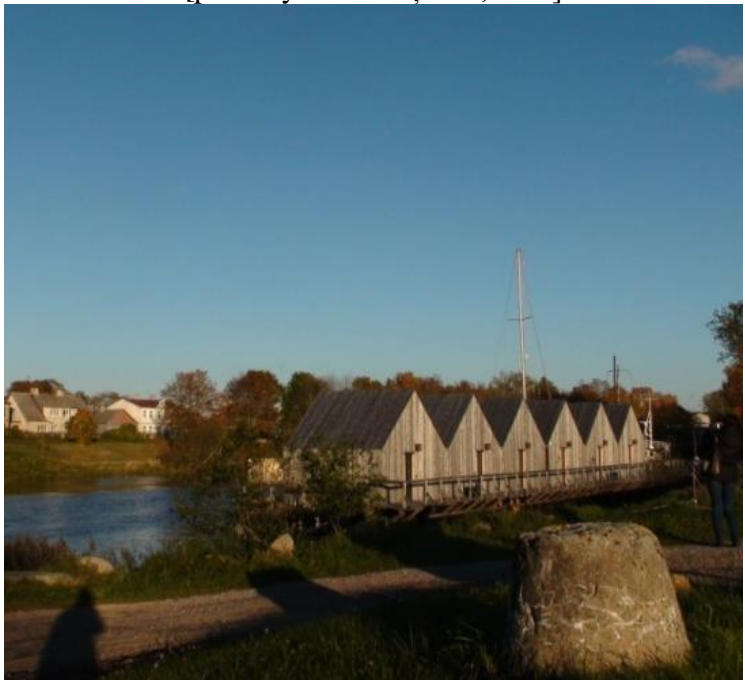

Fig. 12. Tourist accommodations, with boat planks [photo by A. Ziemelniece, 2017]

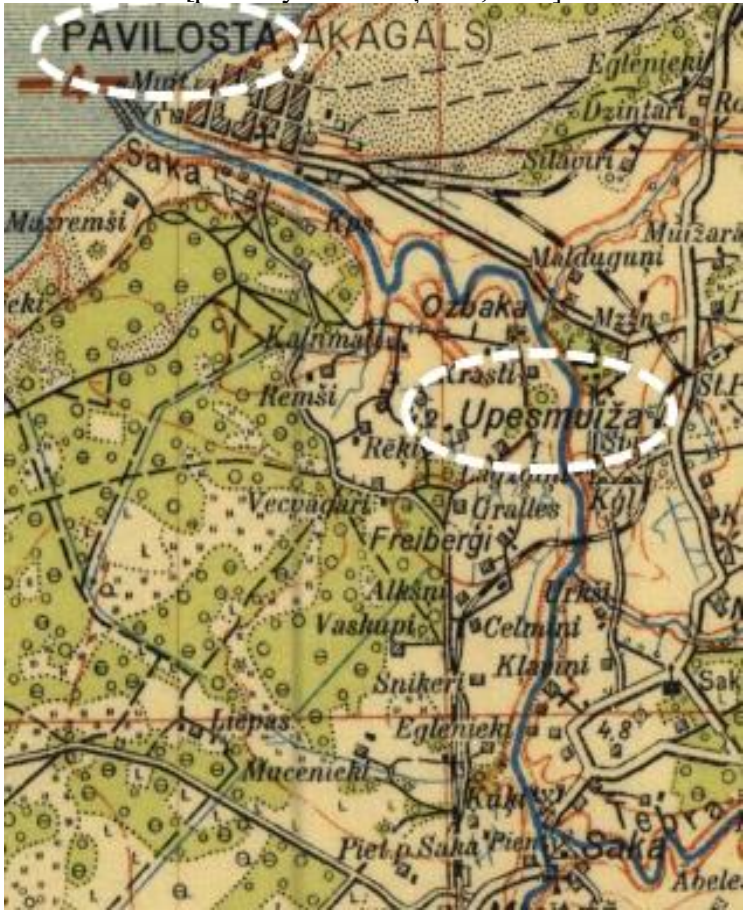

Fig. 13. Pāvilosta and Upesmuiža (Sackenhausen) railway network linking [created by authors; 6]

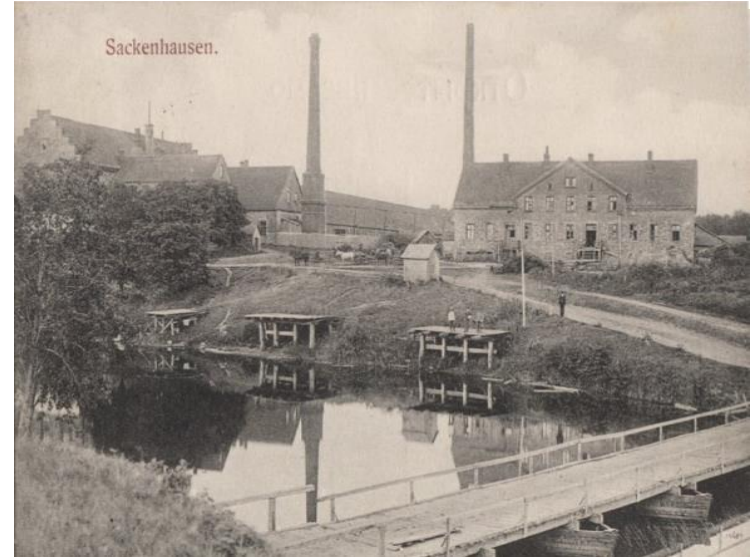

Fig. 14. Chimneys of the brick kiln and the distillery of Upesmuiža [http://www.zudusilatvija.lv/objects/object/3614/] with the Leja Evangelic Lutheran Church of Saka. During the reign of Duke Jacob (1642-1682), in their interests, the port of Saka was used by merchants of Aizpute. Within a year, the port was entered by $50-150$ merchant vessels, mostly from Holland. The busy port life was interrupted by the Swedish-Polish war. Until today, one of the port warehouses has survived [9].

\section{Conclusion}

The transformation of the industrial heritage of the municipality of Pāvilosta has been affected by a number of historical periods. The beginnings of the development of the locality were contributed by the nearness of Liepāja and the construction of a naval port in the second half of the $19^{\text {th }}$ century. The development of the coastal industrial environment started to emerge in the second half of the $19^{\text {th }}$ century and the emergence of the town of Pāvilosta and its boom, devastating wars in the $20^{\text {th }}$ century (1914-1918, 1940-1945), the time of the free state (1918-1940), the Soviet occupation and collectivization time (1945-1990), the impact of the public attitude, awareness, and legislation of the renewed Latvia on the development of the cultural and historical heritage. Each of the periods heralds the political and economic current, the change of the structure, compositional design or functional significance in the landscape spaces of the industrial heritage.

The awareness and the study of the industrial heritage sites promote the understanding of the stages of development of the society, the development of technologies and the economic activity at the local and a broader context, craft skills, contributions of the industrialization in the national economy.

This is attributable to the recovery process of the identity of Pāvilosta - bringing in a new low-rise residential building that keeps the height, roof slopes, coloring, the architectural and compositional structure of the historic building. 
In turn, the historic manor locations after listing of the land and real estate, are necessary to be attracted to conservation, preserving the brickwork of the old building without losing the scale and nature of the building. In characterizing the areas of the industrial heritage, the diversity of the sites and landscape spaces is observed:

- After the study of the historical documentation, the density of the landscape space of the industrial heritage has become thinner which changes the scale of the historic space;

- The green structures play a major role in the expressiveness of the coastal landscape spaces;
- Waterfronts in most sites have lost their historical significance;

- The sites of the industrial heritage often mark significant verticals in the cultural landscape, determining the identity of the site (the chimneys of the kiln of Upesmuiža, the lighthouse of Akmenrags, the location of the former berth at Pāvilosta. etc.);

- The degraded historical areas occupy a considerable part of the landscape space;

- The development of the industrial heritage is hampered by the today's low economic situation, tax policy, development planning opportunities, population fluctuations in municipalities.

\section{References}

1. Ainavu aizsardzība. VARAM, 2000, 91 lpp.

2. Altbergs T., Augustāne K., Pētersone I. Dzelzceḷi Latvijā. Rīga: Jumava, 2009, 169. lpp.

3. Bells S., Nikodemus O. Rokasgrāmata meža ainavas plānošanai un dizainam. Rīga: Valsts meža dienests, LTS International Ltd., 2000. 75 lpp.

4. Briṇkis J., Buka O. Regionālā attīistība un prognostika pilsētplānošanas kontekstā. Rīga: RTU, 2008, 191 lpp.

5. Briṇkisis J., Buka O. Zemes ìpašumu vērtēšana un taksācija pilsētplānošanā. Rīga: RTU, 2008. 50 lpp.

6. Latvijas karte - 1937.

7. Ministru Kabineta pieņemtais sēdes protokols Nr. 7 "Par Nacionālo programmu "Kultūra". 08.02.2000.

8. Ministru kabinets. Aizsargjoslu likums. 20.06.2016.

9. Pāvilostas muzeja materiāli. 2017.

10. Pūḳis M. Kultūras mantojuma sociālā un ekonomiskāa loma. Rīga: LU, 2011 [tiešsaite 12.11.2017] http://mantojums.lv/media/uploads/dokumenti/petijumi/pukis_kulturas_mantojums_ekosoc_loma.pdf

11. Ržepicka D., Ziemeḷniece A. Context of trade canal and industrial heritage in Liepaja. Rezekne Academy of Technologies. 11th International Scientific and Practical Conference, 2017. [tiešsaite 12.11.2017] http://conferences.ru.lv/index.php/ETR/ETR2017/index

12. Teivens A. Latvijas dzirnavas = Mills in Latvia = Die Mühlen in Lettland. Stokholma: Daugava, 1985. 297 lpp.

\section{INFORMATION ABOUT AUTHORS:}

Dace Ržepicka, Mg. arch., doctoral student at Faculty of Environment and Civil Engineering, Department of Landscape Architecture and Planning of the Latvia University of Agriculture, 22 Liela iela, Jelgava, Latvia, LV-3001. E-mail: dace.rzepicka@inbox.lv

Aija Ziemeḷniece, Dr.arch., Professor at Faculty of Environment and Civil Engineering, Department of Landscape Architecture and Planning of the Latvia University of Agriculture, 22 Liela iela, Jelgava, Latvia, LV-3001. E-mail: aija@k-projekts.lv

Una Īle, Dr. arch., Assist. Prof. (since 2012) at Faculty of Environment and Civil Engineering, Department of Landscape Architecture and Planning of the Latvia University of Agriculture, 22 Liela iela, Jelgava, Latvia, LV-3001. E-mail: una.ile@1lu.lv

Kopsavilkums. Pētot Pāvilostas novada industriālā mantojuma ainavtelpu Baltijas jūras piekrastēe, ir apsekota piecu kilometru plata piekrastes josla, atbilstoši Aizsargjoslu likumam [1] un salīdzināti pieejamie vēstures un arhīvu dati ar esošo situāciju dabā par objektu tipoloǵiju, skaitu un aktuālo stāvokli. Pāvilostas novadā piekrastes joslā industriālo mantojumu veido ražotnes un saimnieciskās būves bijušo muižu īpašumos, kā arī zvejniecības un kuǵniecības objekti, bākas, ceḷu būves un tilti. Industriālajam mantojumam pieder arī 20. gs. sākumā izbūvētais šaursliežu dzelzceḷš un stacijas. Nozīmīgākais industriālais mantojums koncentrējas Pāvilostā, kuras osta dibināta 1879. gadā. Tās uzplaukums aizsākās līdz ar Liepājas karaostas izbūvi un iespēju transportēt turp gan akmeṇus, gan lauksaimniecības produkciju. 20. gs. sākumā Pāvilostā jau bija attīstījusies zvejniecība, kuǵniecība, kuğu būve un tirdzniecība.

Ievērojamākie industriālā mantojuma objekti Pāvilostas novadā ir saglabājušies no 19. gs. 70.-80.gadiem un 20. gs. sākuma. Pēc Otrā pasaules kara 20. gs 50.-80. gados piekrastes laužu dzīve strauji mainījās, iedzīvotāju skaits kara un deportāciju rezultātā samazinājās, ko sekmēja armijas klātbūtne un piekrastes izolētība. Izsīka individuālā zvejniecība, izzuda zvejniecības rīki un atribūti, kā vabas, krāg̣i un steḳi, likvidēti dzelzceḷa objekti.

Zudušas muižu saimniecības ēkas, atlikušās bieži pakḷautas nesaudzīgai, bez arhitektoniskas izpratnes, pārbūvei. Turpretim, Pāvilostā Sakas grīvā norit ostas atjaunošanas darbi un vērojams tūrisma nozares un zvejniecības uzplaukums. Ir svarīgi ne tikai pārbūvēt un reǵenerēt, bet saglabāt materiālas liecības par 
ekonomisko un kultūras izaugsmi industriālo objektu formā. Šī mērķa nodrošinājums būs atkarīgs ne tikai no ekonomiskās attīstības 21.gs. sākumā, bet arī no politiskās un ekonomiskās varas spējas un vēlēšanās atzīt un novērtēt pilsētas izaugsmes nozīmīgākos vēsturiskos posmus".

$\mathrm{Ne}$ vien piekrastes saimnieciski vēsturiskā aprite un apbūve, bet arī dabas pamatne veido lıti spēcīgu kontekstu vietas identitātes uztverei. To rada silueti un kompozicionālie elementi, ko piekrastē veido ainavtelpas horizontāles un vertikāles - kuğu un jahtu masti, bākas, vējdzirnavas. Unikālie skatupunkti no jūras stāvkrasta un tajā sarindotām muižu ēkām, kā arī Pāvilostas vecākās daḷas, ir novada neatkārtojamā bagātība un saudzējamais mantojums. Strauji izzudušais mazbānītis, senā zvejniecība, tīklu žāvēšanas un zivju kūpināšanas darbības liecinieki ir zuduši ainavā un saglabājies vairs tikai kā nemateriālais kultūras mantojums.

Industriālais objekts kā saimnieciskās darbības telpiskais kodols ietekmē ainavas formveidi. Dažādi saimniecisko funkciju veidi ir noteikuši vēsturiskā transporta vietas un gājēju plūsmas. Industriālā vide izsaka telpisko identitāti un veicina noteiktu vietu atpazīstamību. Baltijas jūras piekrastes kultūrainavā no Kolkas līdz Papei industriālās ainavtelpas ir sastopamas gan pilsētvidē, gan lauku ainavā. Mantojuma liecības industriālai videi ir nolasāmas gan materiālā, gan nemateriālā mantojuma veidā. Daudzi objekti un ainavtelpas ap tiem ir zudušas, un liecības ir atrodamas vien arhīvu dokumentos.

Pētījumā izzināta industriālā mantojuma objektiem piegulošo ūdensmalu nozīme Baltijas jūras piekrastē, ietverot upju grīvas un upju posmus. Tās ir vietas, kas vēsturiski nodrošināja transporta sasaisti ar ražošanas objektiem, bet mūsdienās to vērtība ir ainaviskā vide. Vecās ražošanas teritorijas ir potenciāls industriālo parku izveidei un tūrisma uzplaukumam. Attīstāmās teritorijas un objektiem ir jāievērtē aizsargzonas gar ievērojamiem Pāvilostas novada dabas objektiem - Baltijas jūras stāvkrasts, kas pēdējā laikā pakḷauts straujām erozijām, Pāvilostas "Pelēkā kāpa", dabas liegums "Ziemupe". 


\title{
Digital Tools in Landscape Architecture
}

\author{
Natalija N̦itavska, Artūrs Mengots, Latvia University of Agriculture
}

\begin{abstract}
Nowadays professional tools in landscape architecture are more related to digital tools. Landscape architects' hand powered tools have been replaced by computers and digital tools where the traditional techniques are supplemented with 3D modelling and animation for landscape planning in different scales and for different projects levels. The main aim of this paper is to understand and analyse the use of digital tools in landscape architecture and planning in Latvia. For the collection of data for this study a questionnaire was designed and sent to Latvian landscape architects and planners. The questions it included were on how landscape architects and planners use digital tools for the representation of their sketches and ideas and on what kind of digital tools they use in different landscape types and scales. Results showed that all the surveyed landscape architects use digital tools in their everyday professional practice - for landscape design or assessment. Most of them also still use the traditional drawings by hand for draft sketches and ideas, but for communication with public, projects and designs elaborated by digital tools are used. Landscape architects have emphasized the great potential of digital tools for enhancing communication between the landscape architect and the potential user. Digital tools (visualizations, animations, 3D models, etc.) allow the potential user to participate in the landscape planning process and easily imagine the landscape before it is created. Today landscape architects use digital tools to produce the final project presentation images (visualizations) in the landscape planning processes for selling of the project. However, we believe that in future there is a potential for using digital tools more as a communication tool, which can help in contacting clients at various levels of the project implementation, especially in the early stages of the design.
\end{abstract}

Keywords: digital tools, visual communication, landscape architecture

\section{Introduction}

The landscape architect's daily work is associated with landscaping projects of varying scales, specifics and levels, landscape research or landscape management planning. The landscape architect's profession is comparatively new - dating back a little over a hundred years ago, when in 1863 the Board of Central Park Commission in New York City approved a landscape architect's position. Since then, this new profession had officially gained more stability and recognition in its development. In landscape architecture arts and professional knowledge in the field of landscape planning as well as social, ecological and mental aspects are closely intertwined. The results of day-to-day landscape architect's work are often subject to public criticism and perception, thus influencing the ivolvement of the residents in the issues of landscape conservation, planning, design and installation [1].

How do information transfer and communication take place? What tools can a landscape architect use to more effectively prepare quality information, simultaneously making it easier for the residents and clients to perceive the ideas. Nowadays more and more digital tools are being used in the field of landscape architecture, which, on the one hand facilitates the presentation of the results of the remote landscape architect's work, but on the other hand reduces the possibility of using traditional drawing methods without additional processing and also leaves no room for direct communication.

Digital tools allow the landscape architects to use new approaches and methods in planning and communicating about landscape planning, conservation, renovation, or installing issues [2]. In several studies the use of digital tools has been particularly emphasized in landscape architecture and planning in order to improve the project perception and communication among landscape architects and professionals, residents, clients as well as colleagues $[3 ; 4 ; 5 ; 6]$. The use of these digital tools is diverse, and it is adjustable to the projects of different scales and complexity in different stages of development: illustrative, immersive, interactive, intuitive and intensive [7].

So, one of the aspects is the communication with clients and residents. A part of this communication is the emotional design which does not depict the real function of landscape or real proportions, but influence the clients and residents through artistic tools at the emotional level. The authors in their study call that kind of emotional design a "wow effect" which works not only in landscape architecture but also in all the design fields throughout the world and it is more oriented towards selling of the product [8]. Overall, the result of the landscape architect's work - a project or an installed object - includes the emotional aspect of art, therefore it always involves a subjective evaluation.

Exactly what landscape elements or project parts must the clients and residents most often evaluate or read from the designs made by landscape architects? Does the use of versatile digital tools make it easier and with higher qualitaty to perceive the landscape elements? Communication has always been acknowledged to be one of the most significant aspects in the process of landscape design. 
The communication process mainly takes place between the landscape architect and the clients, as well as between two professionals. It is essential when a project is being prepared for real construction [9].

Most often in landscape characterisation such elements as terrain, building or architectural objects, vegetation, roads, surfacing, water elements are used $[10 ; 11 ; 12]$, which overall characterise the versatile essence of the landscape in its elements. But also, such factors as the accessibility of the landscape, its scale, colour, texture and the materials found in the landscape, the emotional factor of the total image, versatility of landscape, its uniqueness and rarity are important $[13 ; 14 ; 15]$. Many of these factors and elements are influenced by subjective perception, thus making it difficult to objectively evaluate the results of the landscape projects.

In our study we have chosen those landscape evaluation criteria which most vividly characterise the project idea, the main parameters and also the essence of the design:

- the placement of elements in the landscape;

- the perception of the design on the whole and the idea of the project;

- vegetation - the existing and planned woody plants;

- inclusion of the objects in the environment, connection with the adjoining territories;

- perception of the proportions of space and elements;

- terrain.

The study deals with the digital tools in landscape architecture. In the current study digital tools have been analysed and compared, information about the most popular digital tools, their choice and use in the field of landscape architecture in Latvia has been obtained and the perception aspects for the types of visualization in the projects of landscape architecture have been evaluated.

\section{Methods}

The study consists of two parts:

- the first part presents information about the most popular digital tools, their choice and habits of use in the field of landscape architecture - the evaluation method of the use of digital tools has been used. This information was obtained from the results of the survey on the habits of the use of digital tools in the field of landscape architecture in Latvia where the representatives involved in the field of landscape architecture participated;

- in the second part of the study the perception aspects of landscape architecture visualization materials have been evaluated by means of the photography method - the evaluation method of perception aspects of visualization types has been used.

\section{The evaluation method of the use of digital tools}

Within the framework of the research, a survey was conducted to find out the most popular digital tools, their choice and use in the field of landscape architecture in Latvia. In Latvia actively working Latvian Association of Landscape Architecture. In the 2017 association had approximately 100 members, who are specialists in the field, of which 23 are certified landscape architects. In the field of landscape architecture in Latvia there is approximately 10 companies. 20 professionals from different education levels in the field of landscape architecture: the secondary professional -1 ; Bachelor - 12; master's degree - 4; $\mathrm{PhD}-3$ was participated in survey. The online survey from March to April of 2017 was carried out using systematic gathering of data from the target audience (professionals of the landscape architecture) characterized by the invitation (e-mail) of the respondents and the completion of the questionnaire over the World Wide Web, using software www.visidati.lv. All twenty individuals who filled in the questionnaire forms were included in the data processing.

The questionnaire consisted of eleven questions. At the beginning of the questionnaire the data about the respondents' education level and working experience in the field of landscape architecture were obtained. Further on the questions were associated with the digital tools the respondents use and the habits of their use, preconditions and goals. At the end of the questionnaire, the survey participant's opinion on digital tools in the field of landscape architecture was collected. MS Excel software was used to compile the collected data and to interpret the results.

\section{Evaluation method of the perception aspects of visualisation materials types}

In the current study the photography comparative method was used in determining the perception aspects of visualization materials types of landscape architecture design. The evaluation of the perception aspects of visualization materials types consisted of four stages (Fig.1).

In the first stage, the materials for designing visual materials were obtained. In the second stage, within the framework of one project, using different digital tools, visual materials were created, which in the third stage were evaluated by the present and future professionals of landscape architecture as well as representatives of other professions. The last stage was planned for summarizing the results obtained from the respondents. 


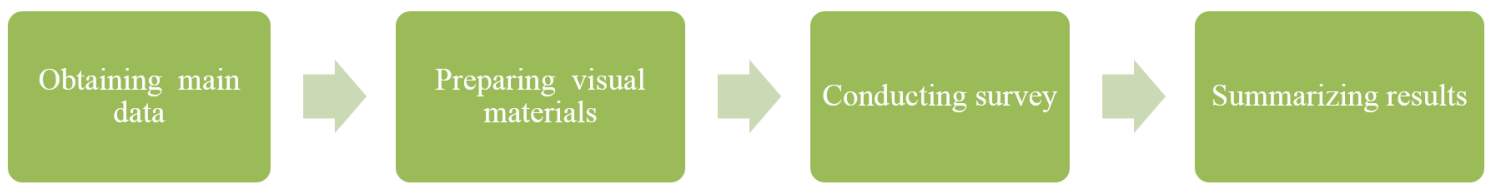

Fig. 1. The stages of the evaluation process of the perception aspects of visualisation types [created by the authors, 2017]

The visual materials were prepared for Tradition Square of the town of Plavinas, in Latvia during the development of the technical project in January/February of 2017. The territory is located in Plavinas among Tirgus, Rainis and Daugava streets. The project has been developed with an aim to regain the lost identity of Tradition Square and connect it with the bank of the Daugava river. According to the project Tradition Square will be developed as a modern public outdoor space, incorporating both - a place for people to gather and fulfil the function of a green zone and recreation, thus radically changing the spatial planning of the existing territory - the network of pathways and layout of a green zone, at the same time showing respect to the existing valuable plantings to be preserved.

In total, four visual materials were prepared a technical plan, an animation, a poster and an interactive $360^{\circ}$ panorama using CAD, 3D modelling and Image processing tools. During the process of designing visual materials, several computer software programmes were used - AutoCad, Sketchup, Adobe Photoshop, V-Ray for SketchUp and Lumion3D.

To have the opinion of Latvia's landscape architects and the professionals of the respective field on the designed visual materials, a queationnaire was created. The online survey was carried out using systematic gathering of data from the target audience (professionals and students of the landscape architecture, Latvian citizens) characterized by the invitation (e-mail) of the respondents and the completion of the questionnaire over the World Wide Web, using software Google forms from March - April of 2017. In total, 81 respondents were involved. The questionnaire included eight questions. The respondents were asked to evaluate the following parameters: the layout of the elements in the planned landscape, perception of the design as a whole and the project idea, vegetation - the existing and planned woody plants, the inclusion of the object in and harmonizing it with the existing environment, linkage with the adjoining territories, perception of the proportions of the space and elements and terrain. At the beginning of the questionnaire the data about the respondents' profession and age were obtained, whereas in the middle part the respondents' opinions about the perceiving capacity of the visualization types were analysed. At the end of the questionnaire the respondents were requested to express their opinion about the visualization types they saw. MS Excel software programme was used for summarizing the data and interpreting the results.

\section{Results}

The results of the evaluation method of the use of digital tools

The number of the respondents taking part in the survey - professionals engaged in the field of landscape architecture - happened to be equally distributed regarding the responses given to the question about their experience in landscape architecture - six of them responded that they have had fitteen or more years of work experience, four of the respondents have had 5-15 years of experience, seven have had 3-5, but three of them 1-3 years of work experience. Most of the respondents - $16(80 \%)$ of them responded that their knowledge is adequate, whereas $3(15 \%)$ responded that they are beginners.

In order to find out about the frequency of the use of digital tools in the design process of landscape architecture in Latvia, the respondents were asked how often they use these tools in their projects. The professionals in the field of landscape architecture use digital tools in each project $(85 \%)$, which indicates the popularity and necessity of digital tools in the work of landscape architects. The results also testify about the need to acquire the digital tools already in the study process so that knowledge and skills are obtained for the designing process.

Giving the response to the question whether the landscape architect him/herself uses digital tools or a professionals is involved, $11(55 \%)$ respondents acknowledged that they both use digital tools themselves and also engage professionals, while 8 $(40 \%)$ respondents use these tools themselves without any professionals' assistance. The responses allowed us to conclude about the lack of skills in the use of digital tools, showing also that there is a need for developing high quality visual material.

According to the respondents' answers to the question about the main prerequisites of the use/nonuse of digital tools in the design process, most often four variants of answers were chosen - the possibility of depicting the landscape (80\%), the time for project developing (75\%), qualitative exchange of information with the customer (70\%) and data exchange possibilities (55\%). 


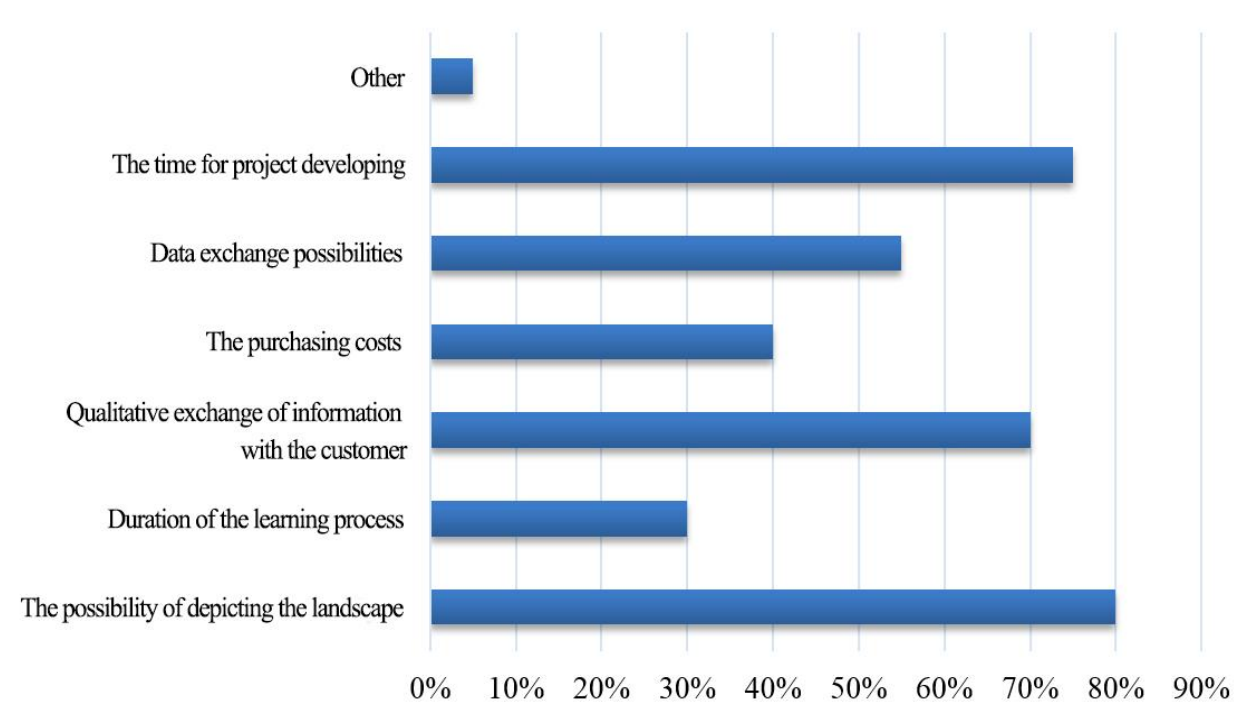

Fig. 2. Main prerequisites of the use/non-use of digital tools in the design process [created by the authors, 2017]

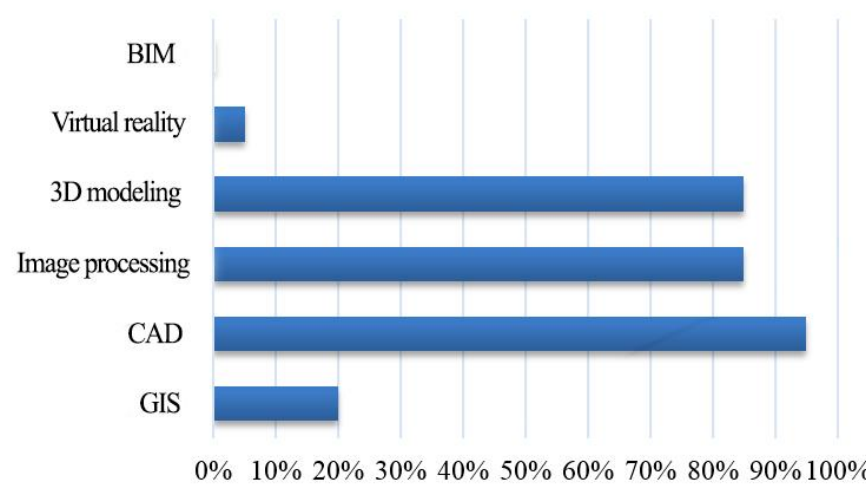

Fig. 3. Most popular digital tools used by landscape architects in Latvia [created by the authors, 2017]

The purchasing costs and duration of the learning process were mentioned as less important - $(40 \%)$ and $(30 \%)$, respectively.

Summarising the responses to the question about the tools used in the designing process, CAD turned out to be most widely used tool $(95 \%)$, followed by image processing $(85 \%)$ and 3D modelling $(85 \%)$. As shown in Fig. 3, GIS, Virtual reality and BIM tools are not widely used among landscape architects in the designing process in Latvia. Almost $100 \%$ use of computer aided design is explained by the development of the plans required for each project, whereas in the process of the development of visual material for presenting the idea, image processing and 3D modelling tools have gained popularity. As the results show (Fig. 3), these tools can be used in combination with each other. As it can be seen in Fig. 3. the tools of Virtual reality and BIM have not gained great popularity among the professionals of landscape architecture. It could be explained by the increasing costs of developing visual materials, the lack of knowledge and skills using the tool as well as the lack of special tools for landscape architects.
Analysing the results of the survey it is obvious that the most popular ways of obtaining a visual material are plans (100\%) and sections (90\%) developed by using CAD tools for the elaboration of technical projects. The next most often used types of obtaining visual material are the photomontage of images $(90 \%)$ and 3D model rendering $(75 \%)$ for better reading of technical plans and presenting ideas. Regarding the VR and BIM tools, they are rather unpopular and less frequently used tools in the design work of landscape architects.

According to the respondents' answers mostly all the tools are used for smaller scale projects, but GIS tools are mostly used for large scale projects (30\%) compared to small scale projects $(15 \%)$. Analysing the results of the use of $3 \mathrm{D}$ modelling there is a small difference between the use of the tools for small scale projects $(65 \%)$ and large-scale projects (45\%) which are mainly influenced by the large time consumption of creating a 3D model, large costs involved and lack of digital data resources.

From the results of the survey with regard to the question about the use of digital tools in the 
process of design it can be concluded that CAD tools are evenly used throughout the entire designing process. As to the use of image processing tools, there is a big difference between the beginning and finishing stages - the greatest majority of respondents acknowledged using this tool at the completing stage of the project $(85 \%)$ and at the beginning fewer respondents $(40 \%)$ do it. Referring to E. Lange who emphasized that $3 \mathrm{D}$ visualization is a necessary constituent part of a project [16] it is also possible to observe among the respondents $55 \%$ of whom use this tool at the beginning of the project and $75 \%$ in the final stage of it.

From the responses to the question about the types of the communication the digital tools are used for, it can be concluded that $\mathrm{CAD}$, image processing and 3D modelling tools are most often used for this purpose. If $\mathrm{CAD}$ tools are more often used for communication with landscape architecture professionals $(90 \%)$ than with clients $(70 \%)$, then in the case of the use of image processing tools it is the other way compared to the communication with clients $(85 \%)$, whereas with regard to communication with the professionals it is $35 \%$.

Most of the landscape architecture professionals who participated in the survey expressed their point of view about the great variety of digital tools and their advantage in terms of higher quality and faster project development. There were also opinions emphasizing the start of a graphic situation analysis and sketching by hand and in the initial stage to use digital tools only for obtaining information and for analytical tasks, but afterwards - to choose the best tool to present the project vision.

Although, mostly 4 response variants prevailed as the main prerequisites for the use/non-use of digital tools in the design process - the possibilities of illustrating the landscape $(80 \%)$, project development time $(75 \%)$, qualitative exchange of information with clients and the possibilities of data exchange $(55 \%)$, the price of the software and the skills to work with the tool had also been emphasized. The price of software, compared to market prices in Latvia, is very often too high, which limits the use of these tools. The lack of skills to handle the available tools was also mentioned, but there is also a desire to learn and expand the knowledge of digital tools. The drawbacks in digital tools themselves were also highlighted. With digital tools, it is hard to keep one's identity and shape one's handwriting, so there are those among the respondents who believe that the very best visualization types are those created by one's own hands. As a disadvantage, the lack of specifically tailored tools for landscape architecture was pointed out. The digital tools for the needs of landscape architects are not fully developed due to the lack of plant assortment, or it is not sufficiently realistic in 3D modelling, and terrain modelling and object integration in it, is complicated and requires additional work.

Obteined results from the survey about the use of digital tools in Latvia are similar as they are in another survey which was made in Norwey where the aim for survey was to find out the most common visualization methods used in practice. Results shows that the most common used visualization methods in landscape architecture companies in Norway are 2D maps and drawings followed by hand drawings and 3D models [5].

\section{The results of the evaluation method of the perception aspects of visualization materials types}

In the online survey participated 32 citizens, 26 professionals and 22 landscape architecture students.

Responding to the first question on how the placement of elements is perceived, the residents (75\%) and students $(60 \%)$ admitted that it is very easy to perceive through animation, whereas the professionals considered that it is easier to perceive by means of a poster $(62 \%)$. The representatives of all three groups acknowledged that all four visual types may help serve for the perception of the existing and planned placement of design elements.

The summarized results show how important the animation visualization type is for the perception of the design of the project. All three respondent groups - residents $78 \%$, professionals - $62 \%$ and students $64 \%$ considered this type to be the most easily perceivable one. The residents and students had emphasized the fact that the perceiving of the design by means of technical drawings was more difficult rather than easy.

Regarding the question of how the existing and planned woody plants, shrubs and perennials are perceived, the students and residents responded that most easily it could be done by means of animation and with an interactive panorama. The students and residents emphasized that with technical drawings it is rather more difficult than easy to perceive information about vegetation. The results summarized in Table 2 demonstrate that professionals do not have any difficulties in perceiving information of all types of visualization, but with animation and the interactive $360^{\circ}$ panorama it is the easiest to do.

The responses to the question of how perceivable the inclusion of the object is into the surrounding environment are shown in Table 3, which shows that for the residents it is most easily perceived by means of animation, but the most difficult way turned out to be technical drawings. Similarly, also the students mentioned that the easiest link of the design object 
TABLE 1

The evaluation of design and composition perception [created by the authors, 2017]

\begin{tabular}{|c|c|c|c|c|c|c|c|c|}
\hline \multicolumn{9}{|c|}{ Clients and inhabitants } \\
\hline & $\begin{array}{c}\text { Tehnical } \\
\text { drawings }\end{array}$ & \multicolumn{2}{|c|}{ Poster } & \multicolumn{2}{|c|}{ Animation } & \multicolumn{2}{|c|}{$\begin{array}{c}\text { Interactive } 360^{\circ} \\
\text { Panorama }\end{array}$} \\
\hline Very easy & 4 & $25 \%$ & 6 & $19 \%$ & 25 & $78 \%$ & 20 & $63 \%$ \\
\hline Easy & 6 & $9 \%$ & 11 & $34 \%$ & 7 & $22 \%$ & 11 & $34 \%$ \\
\hline Hard & 9 & $31 \%$ & 13 & $40 \%$ & 0 & $0 \%$ & 1 & $3 \%$ \\
\hline Very hard & 13 & $40 \%$ & 2 & $6 \%$ & 0 & $0 \%$ & 0 & $0 \%$ \\
\hline
\end{tabular}

\begin{tabular}{|c|c|c|c|c|c|c|c|c|}
\hline Professionals & \multicolumn{2}{|c|}{$\begin{array}{c}\text { Tehnical } \\
\text { drawings }\end{array}$} & \multicolumn{2}{|c|}{ Poster } & \multicolumn{2}{|c|}{ Animation } & \multicolumn{2}{|c|}{$\begin{array}{c}\text { Interactive } 360^{\circ} \\
\text { Panorama }\end{array}$} \\
\hline Very easy & 6 & $23 \%$ & 10 & $38 \%$ & 16 & $62 \%$ & 13 & $50 \%$ \\
\hline Easy & 9 & $35 \%$ & 13 & $50 \%$ & 10 & $38 \%$ & 10 & $38 \%$ \\
\hline Hard & 11 & $42 \%$ & 3 & $12 \%$ & 0 & $0 \%$ & 3 & $12 \%$ \\
\hline Very hard & 0 & $0 \%$ & 0 & $0 \%$ & 0 & $0 \%$ & 0 & $0 \%$ \\
\hline
\end{tabular}

\begin{tabular}{|c|c|c|c|c|c|c|c|c|}
\hline Students & \multicolumn{1}{|c|}{$\begin{array}{c}\text { Tehnical } \\
\text { drawings }\end{array}$} & \multicolumn{2}{|c|}{ Poster } & \multicolumn{2}{|c|}{ Animation } & \multicolumn{2}{|c|}{$\begin{array}{c}\text { Interactive } 360^{\circ} \\
\text { Panorama }\end{array}$} \\
\hline Very easy & 3 & $14 \%$ & 11 & $50 \%$ & 14 & $64 \%$ & 11 & $50 \%$ \\
\hline Easy & 6 & $27 \%$ & 6 & $27 \%$ & 8 & $36 \%$ & 9 & $41 \%$ \\
\hline Hard & 7 & $32 \%$ & 5 & $23 \%$ & 0 & $0 \%$ & 2 & $9 \%$ \\
\hline Very hard & 6 & $27 \%$ & 1 & $5 \%$ & 0 & $0 \%$ & 0 & $0 \%$ \\
\hline
\end{tabular}

TABLE 2

The evaluation of vegetation perception [created by the authors, 2017]

\begin{tabular}{|c|c|c|c|c|c|c|c|c|}
\hline \multicolumn{2}{|c|}{ Clients and inhabitants } \\
\hline & $\begin{array}{l}\text { Tehnical } \\
\text { drawings }\end{array}$ & \multicolumn{2}{|c|}{ Poster } & \multicolumn{2}{|c|}{ Animation } & \multicolumn{2}{c|}{$\begin{array}{c}\text { Interactive } 360^{\circ} \\
\text { Panorama }\end{array}$} \\
\hline Very easy & 4 & $13 \%$ & 6 & $19 \%$ & 25 & $78 \%$ & 20 & $63 \%$ \\
\hline Easy & 6 & $19 \%$ & 11 & $34 \%$ & 6 & $19 \%$ & 11 & $34 \%$ \\
\hline Hard & 9 & $28 \%$ & 13 & $41 \%$ & 1 & $3 \%$ & 1 & $3 \%$ \\
\hline Very hard & 13 & $41 \%$ & 2 & $6 \%$ & 0 & $0 \%$ & 0 & $0 \%$ \\
\hline
\end{tabular}

\begin{tabular}{|c|c|c|c|c|c|c|c|c|}
\hline Professionals & \multicolumn{9}{|c|}{$\begin{array}{l}\text { Tehnical } \\
\text { drawings }\end{array}$} & \multicolumn{2}{|c|}{ Poster } & \multicolumn{2}{|c|}{ Animation } & \multicolumn{2}{|c|}{$\begin{array}{c}\text { Interactive } 360^{\circ} \\
\text { Panorama }\end{array}$} \\
\hline Very easy & 7 & $27 \%$ & 5 & $19 \%$ & 15 & $62 \%$ & 15 & $58 \%$ \\
\hline Easy & 15 & $58 \%$ & 16 & $62 \%$ & 10 & $38 \%$ & 9 & $35 \%$ \\
\hline Hard & 4 & $15 \%$ & 5 & $19 \%$ & 0 & $0 \%$ & 2 & $8 \%$ \\
\hline Very hard & 0 & $0 \%$ & 0 & $0 \%$ & 0 & 0 & 0 & $0 \%$ \\
\hline
\end{tabular}

\begin{tabular}{|c|c|c|c|c|c|c|c|c|}
\hline Students & \multicolumn{1}{|c|}{$\begin{array}{l}\text { Tehnical } \\
\text { drawings }\end{array}$} & \multicolumn{2}{|c|}{ Poster } & \multicolumn{2}{|c|}{ Animation } & \multicolumn{2}{|c|}{$\begin{array}{c}\text { Interactive } 360^{\circ} \\
\text { Panorama }\end{array}$} \\
\hline Very easy & 3 & $14 \%$ & 5 & $23 \%$ & 15 & $68 \%$ & 13 & $59 \%$ \\
\hline Easy & 7 & $32 \%$ & 11 & $50 \%$ & 7 & $32 \%$ & 9 & $41 \%$ \\
\hline Hard & 12 & $54 \%$ & 5 & $23 \%$ & 0 & $0 \%$ & 0 & $0 \%$ \\
\hline Very hard & 0 & $0 \%$ & 1 & $5 \%$ & 0 & $0 \%$ & 0 & $0 \%$ \\
\hline
\end{tabular}

with the environment could be perceived by means of animation and interactive $360^{\circ}$ panorama. Analysing the results presented by respondents who are professionals in landscape architecture it was clear that all types of visualization are easy to perceive.

After summarizing the results in Table 4, it can be seen that residents and students encountered problems regarding the perception of space and element proportions with two-dimensional visualizations - technical drawings and posters. It is just the opposite when complementing twodimensional visualization types with animation and interactive $360^{\circ}$ panorama types - the designed
TABLE 3

The evaluation of object inclusion

into surrounding perception [created by the authors, 2017]

\begin{tabular}{|c|c|c|c|c|c|c|c|c|}
\hline \multicolumn{2}{|c|}{ Clients and inhabitants } \\
\hline & $\begin{array}{c}\text { Tehnical } \\
\text { drawings }\end{array}$ & \multicolumn{2}{|c|}{ Poster } & \multicolumn{2}{|c|}{ Animation } & \multicolumn{2}{|c|}{$\begin{array}{c}\text { Interactive } 360^{\circ} \\
\text { Panorama }\end{array}$} \\
\hline Very easy & 2 & $6 \%$ & 9 & $28 \%$ & 27 & $84 \%$ & 17 & $53 \%$ \\
\hline Easy & 7 & $22 \%$ & 10 & $31 \%$ & 4 & $13 \%$ & 12 & $38 \%$ \\
\hline Hard & 15 & $47 \%$ & 12 & $38 \%$ & 1 & $3 \%$ & 3 & $9 \%$ \\
\hline Very hard & 8 & $25 \%$ & 1 & $3 \%$ & 0 & $0 \%$ & 0 & $0 \%$ \\
\hline
\end{tabular}

\begin{tabular}{|c|c|c|c|c|c|c|c|c|}
\hline Professionals & \multicolumn{10}{|c|}{$\begin{array}{l}\text { Tehnical } \\
\text { dravings }\end{array}$} & \multicolumn{2}{|c|}{ Poster } & \multicolumn{2}{|c|}{ Animation } & \multicolumn{2}{|c|}{$\begin{array}{c}\text { Interactive } 360^{\circ} \\
\text { Panorama }\end{array}$} \\
\hline Very easy & 5 & $19 \%$ & 7 & $27 \%$ & 15 & $58 \%$ & 15 & $58 \%$ \\
\hline Easy & 14 & $54 \%$ & 13 & $50 \%$ & 7 & $27 \%$ & 7 & $27 \%$ \\
\hline Hard & 7 & $27 \%$ & 6 & $23 \%$ & 4 & $15 \%$ & 3 & $12 \%$ \\
\hline Very hard & 0 & $0 \%$ & 0 & $0 \%$ & 0 & $0 \%$ & 1 & $3 \%$ \\
\hline
\end{tabular}

\begin{tabular}{|c|c|c|c|c|c|c|c|c|}
\hline Students & $\begin{array}{c}\text { Tehnical } \\
\text { drawings }\end{array}$ & \multicolumn{2}{|c|}{ Poster } & \multicolumn{2}{|c|}{ Animation } & \multicolumn{2}{|c|}{$\begin{array}{c}\text { Interactive } 360^{\circ} \\
\text { Panorama }\end{array}$} \\
\hline Very easy & 1 & $5 \%$ & 1 & $5 \%$ & 13 & $59 \%$ & 13 & $58 \%$ \\
\hline Easy & 5 & $23 \%$ & 13 & $59 \%$ & 8 & $36 \%$ & 5 & $23 \%$ \\
\hline Hard & 9 & $41 \%$ & 8 & $36 \%$ & 1 & $5 \%$ & 3 & $14 \%$ \\
\hline Very hard & 7 & $32 \%$ & 0 & $0 \%$ & 0 & $0 \%$ & 1 & $5 \%$ \\
\hline
\end{tabular}

TABLE 4

The evaluation of space and element proportions perception [created by the authors, 2017]

\begin{tabular}{|c|c|c|c|c|c|c|c|c|}
\hline \multicolumn{2}{|c|}{ Clients and inhabitants } \\
\hline & Tehnical drawings & \multicolumn{2}{|c|}{ Poster } & \multicolumn{2}{|c|}{ Animation } & \multicolumn{2}{c|}{$\begin{array}{c}\text { Interactive } 360^{\circ} \\
\text { Panorama }\end{array}$} \\
\hline Very easy & 2 & $6 \%$ & 7 & $22 \%$ & 26 & $81 \%$ & 19 & $59 \%$ \\
\hline Easy & 7 & $22 \%$ & 7 & $22 \%$ & 5 & $16 \%$ & 10 & $31 \%$ \\
\hline Hard & 10 & $31 \%$ & 15 & $47 \%$ & 1 & $3 \%$ & 3 & $9 \%$ \\
\hline Very hard & 13 & $41 \%$ & 3 & $9 \%$ & 0 & $0 \%$ & 0 & $0 \%$ \\
\hline
\end{tabular}

\begin{tabular}{|c|c|c|c|c|c|c|c|c|}
\hline \multicolumn{9}{|c|}{ Professionals } \\
\hline & \multicolumn{2}{|c|}{ Tehnical drawings } & \multicolumn{2}{|c|}{ Poster } & \multicolumn{2}{|c|}{ Animation } & \multicolumn{2}{|c|}{$\begin{array}{c}\text { Interactive } 360^{\circ} \\
\text { Panorama }\end{array}$} \\
\hline Very easy & 3 & $12 \%$ & 3 & $12 \%$ & 17 & $65 \%$ & 12 & $46 \%$ \\
\hline Easy & 12 & $46 \%$ & 16 & $62 \%$ & 7 & $27 \%$ & 12 & $46 \%$ \\
\hline Hard & 11 & $42 \%$ & 6 & $23 \%$ & 2 & $8 \%$ & 2 & $8 \%$ \\
\hline Very hard & 0 & $0 \%$ & 1 & $4 \%$ & 0 & $0 \%$ & 0 & $0 \%$ \\
\hline
\end{tabular}

\begin{tabular}{|c|c|c|c|c|c|c|c|c|}
\hline Students & \multicolumn{10}{|c|}{ Tehnical drawings } & \multicolumn{2}{|c|}{ Poster } & \multicolumn{2}{|c|}{ Animation } & \multicolumn{2}{|c|}{$\begin{array}{c}\text { Interactive } 360^{\circ} \\
\text { Panorama }\end{array}$} \\
\hline Very easy & 1 & $5 \%$ & 1 & $5 \%$ & 14 & $64 \%$ & 11 & $50 \%$ \\
\hline Easy & 5 & $23 \%$ & 10 & $45 \%$ & 7 & $32 \%$ & 9 & $41 \%$ \\
\hline Hard & 10 & $45 \%$ & 10 & $45 \%$ & 1 & $5 \%$ & 1 & $5 \%$ \\
\hline Very hard & 6 & $27 \%$ & 1 & $5 \%$ & 0 & $0 \%$ & 1 & $5 \%$ \\
\hline
\end{tabular}

spaces and the shapes of their elements become more easily perceived. It is also recognized by professionals that by complementing the twodimensional animation methods with animation, an interactive $360^{\circ}$ panorama makes the space easier to perceive.

With regard to the question of how the terrain is perceived, $78 \%$ of the residents and $68 \%$ of the students responded that the terrain is most easily perceived by animation. In a slightly smaller number of questionnaires, $59 \%$ of residents and $64 \%$ of students responded that the terrain is very easy to perceive with the help of interactive $360^{\circ}$ panorama, whereas in technical drawings and 
posters the terrain is difficult to perceive. The professionals noted that the terrain was equally easy to perceive in all the types of visualization, but it is most easily perceived in animation (58\%). The respondents acknowledged that this issue is somewhat confusing for them due to the non-expressive terrain, but they themselves already acknowledged that the terrain is flat, which they were able to see in successful visualizations and landscape elevation.

All three groups of respondents - residents $94 \%$, professionals $-77 \%$ and students $-73 \%$ acknowledged that the project idea is most easily perceived by means of animation. The residents $(72 \%)$, unlike students $(55 \%)$ and professionals $(38 \%)$, noted that the Interactive $360^{\circ}$ panorama in general is also easy to perceive. Some respondents from the general population emphasized that for them the Interactive $360^{\circ}$ panorama was better to perceive than animation, since it is not so intense. Due to great experience and working with CAD tools on a daily basis, most professionals admitted that technical projects are also easy to perceive, unlike residents and students most of whom considered that information is difficult to perceive.

At the end of the survey the respondents had an opportunity to express their opinion about the visual materials and visualizations they saw. The professionals acknowledged that it was best to perceive a project when it is viewable in both twodimensional and three-dimensional ways, since in each aspect of visualization some other aspect can be better evaluated. The perception of information from CAD technical drawings is facilitated by the fact that the professionals work with them on a daily basis. The professionals also acknowledged that the interactive panorama and animation are more intended for clients and other people who are not involved in the design. The technical drawings and the project plan make it easier to perceive the overall composition of the project, the proportions, the connection with the surroundings, but the place, the design of the landscaping elements, the amenities and the choice of plantings are easier to perceive in $3 \mathrm{D}$ animation and in the interactive panorama. The respondents from among the population and students acknowledged that the animation and interactive panorama visualization methods perfectly complement the $2 \mathrm{D}$ visualization types, thus obtaining more complete information about the project.

Similar research about visualisation methods was made in the Virtual Reality laboratory at the Norwegian University of Life Sciences. Hansen explored how different methods of visualization are understood and experienced by lay people and professionals. Results from the VR-Lab study showed the same results as survey made by research authors that the $3 \mathrm{D}$ realistic model visualization was the most engaging for both professionals and lay people [5].

\section{Conclusions}

In recent years, more and more attention has been paid to the use of digital tools and project visual representing in Latvia. The standards for visual representing materials of the project have been developed, as well as tasks for the digitalization of the construction documents circulation, facilitating a gradual transition to electronic data circulation and storage, using the latest technologies and world best practices.

Summing up information about digital tools, their disadvantages are clear: the lack of qualitative specially designed tools for landscape architects when working in 3D modelling - lack of plant assortment or it is not sufficiently realistic and for the modelling of the landscaping elements in the terrain and the integration of objects in it is complicated and requires additional work; the lack of specific BIM software to provide better quality collaboration with professionals of other sectors during the design process and efficient file sharing.

Although digital design possibilities, project development time, qualitative exchange of information with the client and data exchange opportunities are acknowledged to be the main prerequisites for the use/ non-use of a digital tool in the design process, the software price and skills to operate the tool have also been mentioned. The prices of software, compared to market prices in Latvia in this respective field, in respondent's opinion are very often too high, which limits the use of these tools. There is also a lack of skills in handling the digital tools available, but there is also a desire to acquire and expand knowledge about these tools.

Landscape architecture professionals in Latvia mainly use $\mathrm{CAD}$, image processing and 3D modelling tools during project development. GIS, Virtual reality and BIM tools are not widely used in the design process among landscape architects in this country. An almost 100 percent use of computer-aided design tools is explained by the development of plans that are required for each project. For the developing of the visual material, while presenting the idea, the image processing and 3D modelling tools have gained great popularity. According to the results of the survey these tools tend to be used in combination with each other.

The results of the survey of determining the perception aspects of visual types showed that the technical project does not fully allow the residents to get an idea of the project, but the $3 \mathrm{D}$ visualization types - animation and the 
interactive $360^{\circ}$ panorama perfectly complement the $2 \mathrm{D}$ visualization types. Among the residents there were also respondents who emphasized that the interactive $360^{\circ}$ panorama is better than animation because it is less intense. The professionals acknowledged that it is best to perceive a project when it is viewable both two-dimensionally and three-dimensionally, as in each type of visualization it is possible to appreciate some other aspect of the project. The perception of information from CAD technical drawings for professionals is facilitated by the fact that they work with them on a daily basis.

Complex use of digital tools in landscape design process are more helpful for understanding of landscape projects parts: placement of landscape elements; design; vegetation; connection of the planned object with the surrounding environment; proportion of space and elements; terrain.

\section{References}

1. Newton, N. T. Design on the land: the development of landscape architecture. Cambridge, Mass.: Belknap Press of Harvard University Press, 1971. 744 p. ISBN 9780674198708

2. Nijhus, S. New Tools: Digital media in landscape architecture. The need for design: Exploring Dutch landscape architecture. [online] Vlug, J. et al. (eds.), Van Hall Larenstein University of Applied Sciences, 2013. p. 86-97. [cited 28.06.2016.] http://repository.tudelft.nl/islandora/ object/uuid:94b6d665-c4b7-4425-ba32-9d7a59141e5d?coll ection $=$ research

3. Brown, G., Weber, D. Public Participation GIS: A new method for national park planning. Landscape and Urban Planning. Elsevier B.V: 2011, Vol. 102, Issue 1, p. 1-15. ISSN 0169-2046

4. Dannevig, T., Thorvaldsen, J. A. Immersive Virtual Reality in Landscape Planning. Master thesis, Norwegian University of Life Sciences, Department of Landscape Planning, 2007.

5. Hassan, R. Mot et digitalt $3 \mathrm{D}$ visualiseringsverktøy for kommunikasjon og samarbeide innen planlegging og design. KART OG PLAN 4, 2014. p 300- 308.

6. Yan, J. An Evaluation of Current Applications of 3D Visualization: Software in Landscape Architecture. [online] Master thesis, Utah State University, 2014. [cited 14.11.2017.] https://digitalcommons.usu.edu/etd/3882/

7. Orland B., Budthimedhee, K., Uusitalo, J. Considering virtual worlds as representations of landscape realities and as tools for landscape planning. Landscape and urban planning. Elsevier B.V: 2001, Vol. 54, p. 139-148. ISSN 01692046

8. Desmet P. M. A., Porcelijn, R., van Dijk, M. B. Emotional Design; Application of a Research-Based Design Approach. Knowledge, Technology \& Policy, Springer Netherlands, 2007, Vol. 20, p. 141-155. ISSN 1874-6314

9. Nielsen, D., Fleming, M. J., Kumarasuriyar, A. C., Gard, S. Digital design communication: Measuring learner technological prowess and selfefficacy in problem resolution. [online] Proceedings of INTED 2010 International Technology, Education and Development Conference, 8 - 10 March 2010, Hotel SH Valencia Palace, Valencia, Spain. [cited 14.11.2017.] https://eprints.qut.edu.au/33145/1/c33145.pdf

10. Visual Resource Contrast Rating. [online] BLM Manual Handbook H_8431_1. U.S. Department of Interior, Washington, DC, 1986 [cited 18.03.2011.]. http://www.blm.gov:80/nstc/VRM/8431.html, Date accessed: April 4, 2008.

11. Landau, B., Jackendoff, R. "What" and "where" in spatial language and spatial cognition. Behavioral and Brain Sciences, 1993, Vol. 16, p. 217-238. ISNN 2160-5874.

12. Cultural sustainability: Aligning aesthetics and ecology. Placing nature: culture and landscape ecology. Ed. by J.I. Nassauer. Washington DC: Island Press, 1997, p. 67-83. ISSN 1572-9761.

13. Paklone, I., Strautmanis, I. Vizuālā vēstījuma nozīme mūsdienu pilsētvides veidošanā. RTU zinātniskie raksti: 10. sērija: Arhitektūra un pilsētplānošana. Rīga: RTU, 2009, 3. sēj., 31.-39. lpp. ISNN 1691-4333.

14. Bell, D. S.A. Mythscapes: Memory, Mythology and National Identity. British Journal of Sociology, 2003, Vol. 54, No. 1, p. 63-81. ISSN1465-3346.

15. Ziemeḷniece, A. Estêtiskā kvalitāte ainaviskajā telpā. Jelgava: Latvijas Lauksaimniecības universitāte, 1998. 96 lpp.

16. Lange, E. The limits of realism: Perceptions of virtual landscapes. Landscape and Urban Planning. Elsevier B.V: 2001, Vol. 54, p. 163-182. ISSN 0169-2046

INFORMATION ABOUT AUTHORS:

Artūrs Mengots, Lector at Latvia University of Agriculture, Faculty of Environment and Civil Engineering, Departament of Landscape architecture and Planning. E-mail: artursmengots2@inbox.lv

Natalija Nitavska, Asoc.professor at Latvia University of Agriculture, Faculty of Environment and Civil Engineering, Departament of Landscape architecture and Planning. E-mail: natalija.nitavska@llu.lv

Kopsavilkums. Mūsdienu ainavas plānošanas process ir cieši saistīts ar digitālo rīku lietošanu dažāda mēroga un atšķirīgo izstrādes etapu projektos. Pētījumā mērḳis apkopot un analizēt ainavu arhitektu paradumus un aspektus digitālo rīku izmantošanā Latvijā. Pêtījums veiks izmantojot aptaujas metodi, apkopojot un analizējot datus par to, kādus digitālu rīkus ainavu arhitekti izmato savā darbā atšḳiirīgā mēroga un dažāău mērķu sasniegšanai. Rezultāti apkopo datus par digitālo rīku lietošanu un uztveršanu no klientu un kolēǵu puses. Jautājumi uzdoti par digitālo rīku izmantošanas biežumu, kur līderība ir AutoCad, 3D modelēšanas un attēlu apstrādes rīkiem; jautājums par ierobežojošiem faktoriem digitālo rīku 
izmantošanai atklāj problemātiku ar laika ietilpīgiem procesiem, apgūstot jaunus rīkus un ievadot informāciju, ka ar̄̄ pašu programmu dārgumu. Otra pētījuma daḷa ietver klientu un kolēguu, jeb sadarbības partneru aptauju, kas sniedz atbildes par digitālo rīku lomu projekta uztveres procesā un komunikācijas procesā. Rezultāti parāda, ka ar animācijas palīdzību visvieglāk uztverama projekta kopēja kompozīcija, vietas mērogs un elementu proporcijas, bet 3D rīkiem ir ierobežots Latvijā augošās veǵetācijas sortiments, kas ierobežo projekta precīzo attēlošanu. Tehniskie rasējumi grūti izprotami klientiem un iedzīvotājiem, bet viegli uztverami profesionāļiem, no kuriem tie spēj nolasīt tehniskā rakstura informāciju un specifikācijas. Kopumā nav universālo digitālo rīku un katram projekta etapam un atšķirīgai mērķauditorijai izmantojami atškirīgie digitālie rīki vai to kopas. 


\title{
Zasa (Weesen) Manor and Park
}

\author{
Jānis Zilgalvis, Dr. arch., a full member of the Latvian Academy of Sciences
}

\begin{abstract}
Zasa manor is located in Selonia and presently it stands out mostly due to its magnificent park which has been created in 18th-19th century and which landscape qualities have not been lost until now. The Greig family played a special role in the culture heritage of the manor. The family lived there for a relatively short period from the middle of the 19th century until the Agrarian Reform of Latvia. It is important to conduct the research of the manor's history and cultural environment since there is little information available. In addition, it is necessary to correct some data and statements that have appeared in the previous publications. There is a necessity to include the manor's park in the national list of protected culture heritage monuments.

Keywords: protection and preservation of architectural and cultural heritage, landscape architecture, protection of cultural and historical environment
\end{abstract}

\section{Introduction}

Very few written records are available about Zasa or Weesen manor both in the 19th century and nowadays. Information about this place is negligible and often similar which could be explained by one source of information which is slightly adjusted from source to source or the same. Zasa manor is mentioned and briefly described in the books of Dainis Bruğis [1], Alberts Zarāns [2], some tourist guides, for example, in the publication of Arvīds Plaudis [3], as well as in a brochure in the Estonian language [4]. The author of this article [5] also have described Zasa manor, there are entries about it in encyclopedias [6] and newspaper articles. The last ones are mostly devoted to the park [7], its preservation and current developments in relation to it.

As regards von Sass family, the original owners of the manor, there is no detailed information available about them, but different sources provide varied information about the last owners: they are called Gregh, Greigh, barons Greves, counts of English origin [8], some sources mention their connection with Carskoe Selo management at St. Petersburg, the influence of Gatchina (Гатчино) Gardens in designing Zasa park etc. The aim of the research was to explore the fate of the manors' owners and the property, the design of the park by investigating the available information in literature, internet resources and archives. Initially, it did not produce any results, but then little-known surprising facts were revealed about this remote place of the middle part of Selonia. The article revises and corrects inaccuracies and wrong facts in previous publications.

\section{Owners of the manor in the 18th century and until the 1920s}

In the period from 1644 to 1787 the manor belonged to the von Sass family. In 1680 it belonged to Heinrich von Sass (1636-1706), his wife was Ann Dorothy von Sass, born von Vietinghof-Scheel,

1645-1706), but the first owner was Reinhold von Sass, his father (1602-1648). In 1750 the owner was Gideon von Zass (?-1753), who also owned Scheden manor (the Sass family bought it in 1729). He was the son of Heinrich von Sass. His wife was Margareth Gertrude von Grothuss. There were five sons in the family - Georg, Otto Friedrich, Heinrich, Johann Karl and Reinhold. However, later the owners changed. It is known that on August 25, 1846, Wilhelm von Rummel [9], the former judge of Talsen district and the owner of Sass manor's bonds, passed away (that means that the manor was pledged). Later Wilhelm, allegedly his son, owned the manor; for example, in 1854 and 1861 he allocated funding for reconstruction of Zasa Lutheran church including a new altar piece and pulpit.

In approximately 1865 the pledged manor was bought by Vasily Greig (Грейг). However, before moving on to describing his life and work story, it is necessary to focus on the ancestors of the Greig family. The origins of this family are found in Scotland, in the small port town of Inverkeithing, Fife. The Greigs were not from nobility but their ancestors in the 9th century were related to the king. The family had many descendants forming a kin network in the course of time. The grandfather of Vasily Greigh was widely known and famous Samuel or Samuil Greig (1735-1788), the Russian fleet admiral. In 1764 he as a British naval lieutenant accepted the invitation of the Russian Empress Catherine II (1729-1796) to serve in the Russian navy because he did not see career opportunities in his homeland. He changed his name to Samuil from Samuel. So, he became famous worldwide as Russian fleet admiral due to his superior abilities earning the title of a true member of St. Petersburg Academy of Sciences. He was a military commander, participant of many naval battles, also an expert in shipbuilding and artillery. He took part in formation of Alexander Cannon factory and 
Kronstadt docks, introduced a new signalling system in the fleet, etc. S. Greig was awarded with several orders of the Russian Empire including the Order of St. Andrew, the highest order of chivalry (орден Святого Андрея Первозванного). In 1768 S. Greig married Sarah Cook (1752-1793), a twin sister of James Cook (1728-1779), a famous British explorer. S. Greig died in 1788 during the blockage of the Swedish fleet in the port of Sveaborg. He was buried in the Tallinn Cathedral where the architect of his tomb was G. Quarenghi which was financed by Katherine II. One of S. Greig's son was Alexey Greig (1775-1845), the father of Vasily Greig, who became the owner of Zasa manor. Alexey Greig was a prominent admiral of the Imperial Russian Navy, his godparents were Catherine II and count Alexei Orlov. In 1804 he commanded the Russian Navy in the war against Turkey and France when he was only 30 years old. His career in the navy flourished, and in 1813 he was awarded the rank of vice-admiral and the 1st class of Order of St. Ann (орден Святой Анны первой степени). In 1816 he was appointed the commander of the Black Sea Fleet, a military governor of Nikolayev and Sevastopol. During the Russo-Turkish war in 1828 he was a leader in the attack at the fortress of Anapa. He was awarded the rank of admiral after the victories. A. Greig was a man of various interests and knowledge. He knew several languages, painted, took interest in different scientific areas, later he was appointed an honorary member of the Academy of Sciences. In addition, A. Greig dealt with horticulture, plant acclimatization etc. He was elected a member of the Moscow Society of Naturalists. This fact could explain a myth that Greig, an owner of the Zasa manor, had been a manager of Carskoe Selo (Царское село) and many of design ideas from there implemented in Zasa manor [10]. When Greig became an owner of Zasa property, his father had died some years ago. As regards the position of a manager at Carskoe Selo, the analysis of the Carskoe Selo register of persons from 1710 to 2010 did not reveal any person with such a surname [11]. On the other hand, Vasily Greig had a brother, Samuil Greig, a Russian army general and a minister of finances (1878-1880), who was indirectly related to the park designing culture. In 1870 he proposed to establish Admiralty Park in St. Petesburg to commemorate 200 years of Emperor Peter I (16721725). He was also a president of Russian Emperor's Horticultural Society (Императорское Россйское общество садоводства) [12]. This fact could be the reason why someone without proper knowledge could mention Carskoe Selo in connection with Zasa manor [13].

The personal life of the father of Zasa manor's owner is interesting and unusual. When he was 46, he fell in love with and married Yulia Stalinska
(Rafalovich) (1800-1881) which was of Jewish origin. Intrigues, complaints and lies did not allow this marriage to be publicly recognized. It happened only a little later when their children came to the world and one of them was Vasily Greig, an owner of Sass property. He was born in the city of Nikolaev in Kherson region in 1832 and spent his childhood with his brothers and sisters in St. Petersburg. In 1850 he joined the military service, then took part in the Crimean War. From 1869, V. Greig served as the chairman of the Vidzeme Control Chamber, in 1873 he was promoted to the rank of the colonel, but soon after moving to the civilian office he became a councilor of the court and headed the State Chancellery in St. Petersburg. In 1877 he was assigned a true state counselor that was equal to the rank of general in the military service. After two years, V. Greig was awarded the title of the court's chamberlain of the emperor's palace. In 1885 he became also a member of the Council of the Ministry of Finance. It is hard to say why his choice fell directly on Zasa property, a remote corner of Selia. One of the reasons could be that it was a good offer or he noticed the property, and he liked the place while he was working in Vidzeme Control Chamber. In 1859 V. Greig married Maria Kuming (1837-?), they had four children: two daughters, Vera (1862-1843), Countess Tolstoy after the marriage, and Helen (1871-?), as well as two sons, Alexis (1859 - after 1912) and Samuil (1872-?) [14]. Vasily Greig died in 1902. The manor was inherited by his son Alexis who was mentioned as the last owner in the documents of the agrarian reform with the note that the inalienable possession of the estate's centre now belonged to Nikolay Greig [15], the son of Alexis. Alexis Greig, a headmaster of headquarters, was mentioned in the Richter Address Book as the manor's owner [16]. It is stated in the book that since 1904 he lived in the manor. Its manager was baron N. Hahn.

The life of the Greig family was also witnessed by the chapel located in Zasa church yard opposite the main entrance. It was rectangular, with a semicircular apse. Arvids Gusars, a fellow member of the Board of Monuments, informed the board in 1928: 'when I arrived at Zasa near the church, I found only the foundations of the former chapel. Chapel was demolished 3 years ago by the local manor owner Greig, who was given a chapel along with the manor. The chapel had been built in a Greek style, its facade had been decorated with four marble columns with figurine angels at the top. The building itself had been made up of red bricks. Now one can see a ruined cellar through brick debris' [17]. Currently nothing has been left from the building only the traces of the former foundations in the earth. 


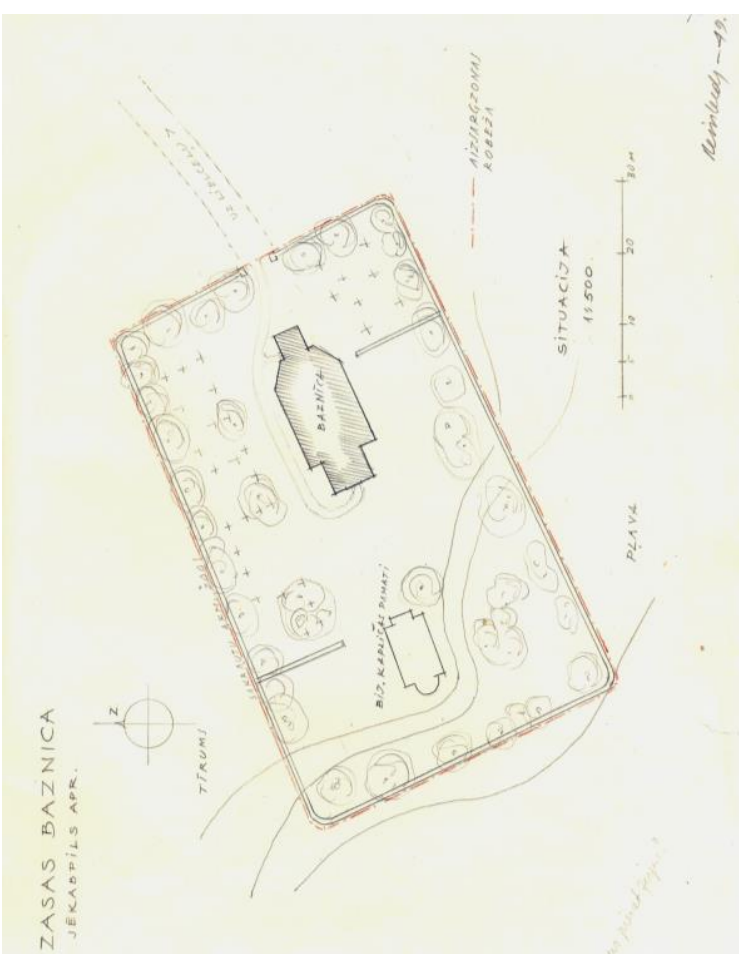

Fig. 1. The layout plan of the Zasa lutheran church and a chapel [State Inspection for Heritage Protection of the Republic of Latvia, Monument Documentation Center, 1928]

The largest part of the land of the manor's estate was divided into 88 newly establish farms during the agrarian reform. Certain areas were left and adjusted for public needs, for example, the parish house, the church, the cemetery, the house for people in need, the brick factory, the parish school etc [18]. The inalienable possession, including watermill, was left to the former owner of the manor. In 1921 it is stated that 'all buildings of the manor are old except cattle shed which also cannot be used otherwise than transferring it to the former owner; other buildings located in the center of the manor have been taken by the parish community' [19].

In 1924 the centre of the manor along with the water and steam mill was purchased by Indrikis Stukulis from Nikolai Greig, the owner of the manor. Stukuls' skillful management of his new property produced remarkable results. After his death, the property was inherited by his son, Vilis Stukuls (1909 - 1996), a prominent horse breeding specialist who was an owner of Zasa in the 1930s. The property was renamed Berrzemnieki to honour the memory of his father, which was the former surname of this family. Famous people of that time enjoyed Zasa hospitality. One of them was Jānis Jaunsudrabiņš, a famous Latvian writer and artist. V. Stukuls wrote in his memoirs about him: ... The day was devoted to walks and painting in Zasa Park. The park provides opportunities not only for relaxation, but also for painting and fishing [20]. V. Stukuls' property was nationalized after 1940, however, when the independence of Latvia was restored, the manor was returned to his heirs, but then it was sold to a private individual.

\section{Manor's buildings}

Unfortunately, there is no information about the estate's buildings in the 19th century. However, in 1921 the inventory list of the buildings [21] made up by J. Klaviņš, a surveyor, registered the following buildings in the territory of the estate; they are numbered in the successive order:

1. a shed with brick poles, shingled roof;

2. a building for drying crop made of boulders, shingled roof in good condition;

2. a an attached building to the barn;

3. a building for drying crop with stone and wooden window;

4. a grain drying building made of boulders covered with shingled roof which has decayed;

5. a dwelling house made of boulders roof insulation is made of cardboard;

6. a school, brick masonry, roof shingles in a bad condition, the school has the second floor;

7. a dwelling house made of stones covered with shingled roof, which is old;

8. a barn made of wood, stone poles, shindlesd roof, old;

9. a horse stable, boulder masonry, shingled roof in good condition;

9.a a horse stable;

9.b a horse stable;

9.c a horse stable;

10. a barn, boulder masonry, shingled roof in good condition;

11. a dwelling house (a castle), wooden, shingled and cardboard roof, the roof has decayed;

11. an attachment to the house;

12. a dwelling house made of bricks, shingled roof;

13. former greenhouse made of bricks, shingled roof, old;

14. a dwelling house made of bricks, shingled roof, two-storied;

15. a horse stable made of bricks, shingled roof, new;

15. an attached building;

16. a barn with brick poles with boards, an old roof, there is a cellar;

17. a dwelling masonry house, shingled roof;

18. former poultry house made of logs with shingled roof, the roof and walls have decayed;

19. a toilet made of boulders with shingled roof;

20. a dwelling house made of logs with shingled roof; the roof and walls have decayed;

21. a barn, with log and stone poles;

22. a dwelling house made of bricks, tile roof;

23. a pub made of stones with shingled roof;

24. a barn made of logs, decayed;

25. former warehouse made of boulders, tile roof, old. 
Not much from the list have been maintained till the present day. The buildings mostly were covered with shingled roofs, only two of them had tile roofs, many barns built in a characteristic manner by installing logs or boards between masonry posts, two from buildings were log cabins but they were in bad condition. Unfortunately, the land plan related to the inventory list was not found in the mentioned archive documents even though the numbers show that there has been one.

Today the building of the rest of the estate center is grouped around a rectangular courtyard, the shape of which is still visible. Only ruins have survived from the masters' old houses - a piece of boulder wall with two symmetrical round window shapes. In the second part of the 19th century a new masters' house was built, but it was burnt down in 1905 . This small building remotely reminded the cottage or the country house in Peterhof [22] built for Russian Emperor Nikolas I by A. Menelas, Menelaws, 1747-1831, an architect of Scottish origin. It was located in Alexandria, in the Emperor's sea coast residence, on the eastern border of Peterhof Low Park. The cottage was built and decorated between 1826 and 1829 in romantic Gothic shapes. In the architecture of Zasa summer cottage (the second half of the $19^{\text {th }}$ century) Gothic shapes dominated, but with the characteristic interpretation in wooden construction techniques, both by means of architectural and decorative solutions - in the window openings, decorations of stair railings, roof gables and elsewhere. The photo of this unusual house was published at the beginning of the $20^{\text {th }}$ century by Dainis Brugis [23] and this is the only known information about this building. A summer residence was suitable for the Greig family because they stayed in Zasa only in a warm season, but winters were spent in Petersburg. The colour of the paint of the house could be chosen to resemble the fashion in the court. The two-storied wooden building had a porch, bay windows; the facades were pompously decorated. We do not know anything about the interior of the manor house. There is only one chair that came from Zasa manor; since 1959 it is in stock of Kruspils castle (Jekabpils History museum). It is known that for some time it was situated in the altar part of Zasa lutheran church [24]. The chair was made in early Renaissance style known as board chairs or Dantes' chairs due to the fact that two flat boards were used instead of legs, one of which extended the backrest.

The ruins of the oldest masters' house reveal a small wooden building on the right, where the post-office was situated already during the agrarian reform. It was built as the Greig's summer cottage after the burning of the previous house. The construction design is simple and traditional to fit in the building planning of a rural town. The side

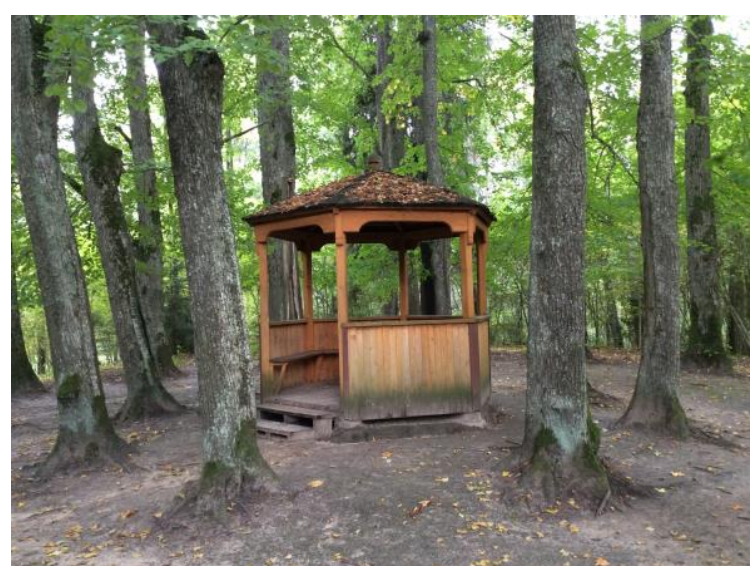

Fig. 2. An arbour on the co-called Cukurkalniņš (Sugar hill) [photo by the author, 2017]

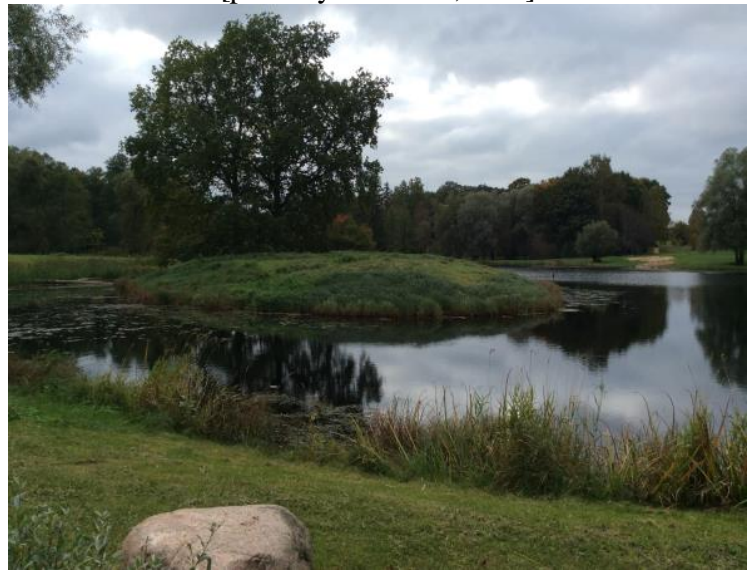

Fig. 3. The view on the Zasa park from the watermill [photo by the author, 2017]

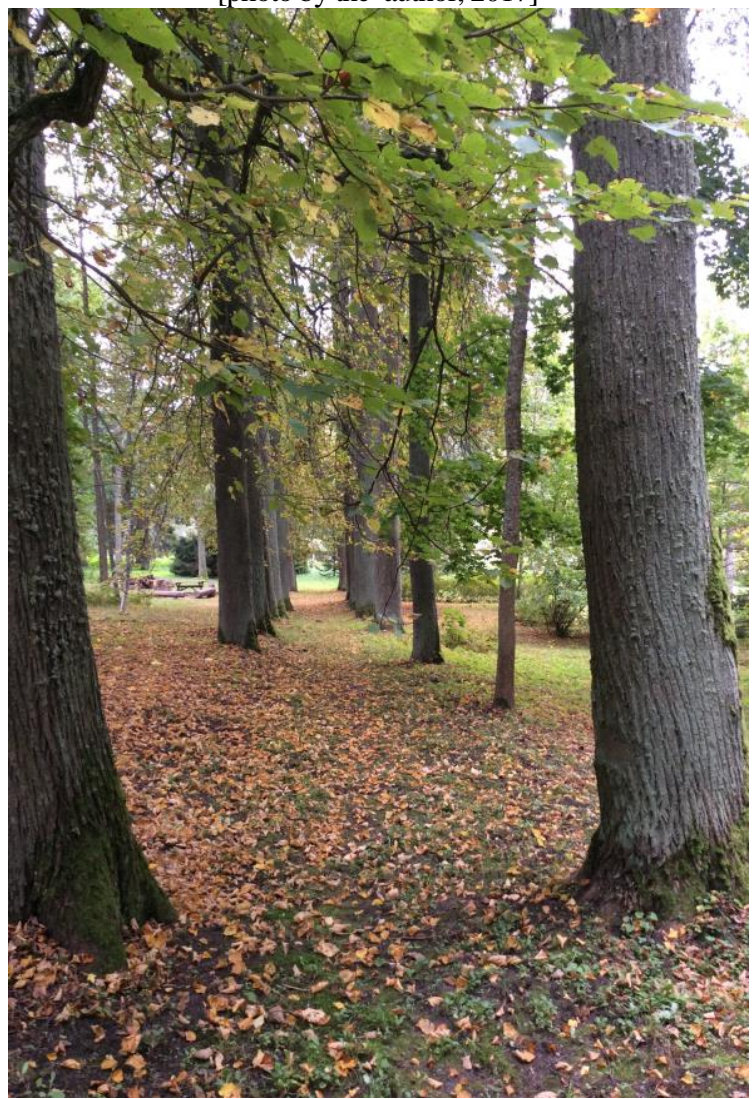

Fig. 4. One of the ancient alleys of the park created during the time of the Sass family [photo by the author, 2017] 
of the yard is occupied by a two-storied building, a former granary. The second floor was added in the 1920 s for the needs of a veterinary office. There are vaulted cellars under the building. There was a laundry once in close distance from this buiding, but its foundations were used to build a new dweling house. The foundations made of boulder masonry are apparent even now. Next to them one can see the remains of another rectangular building the purpose of which is not clear. It is worthwhile to note that it has double cellar walls - approximately one metre distance from each other. The other side of the road leading to the yard is marked by the big enclosure with the boulder masonry building built in the $2^{\text {nd }}$ half of the $19^{\text {th }}$ century with a partly closed yard. One side of it is occupied by a large barn made of boards attached to the building. The estate contains also the former brewery which later served as the house for servants. The two-storied building of the $19^{\text {th }}$ century has a two-sloped roof with semisharpened edges and a cornice with fine shaping. Outside door leaf construction of the servants' house has interesting features (the last quarter of the $19^{\text {th }}$ century). It has paneling construction. Paneling has a double frame, the bottom side is slightly folded, but in its middle there is a circular belt with a roze decoration in the centre. The luxurious door would be hardly meant for the servants' lodgings, most probably it was made for the brewery which had been in this building previously. Other buildings, their remains to be more exact, of the estate are grouped around the brewery (the servants' house). The ruins of the cattle shed, the foundations of some farm building and a cellar cottage belong to them.

The farm buildings include also the mill (19 $9^{\text {th }}$ century) which, as it was mentioned before, was purchased by Indrikis Stukuls in the middle of the 1920s. In 1927 he wrote the following in the application for the adjustments of the mill's land management project: “...my mill consists of four passages, cylinders, wool processing devices, saw mill, planing workshops etc. with $132 \mathrm{HP}$ ',[25]. It seems to be a production unit. The mill is located near the road and it consists of several related volumes. There is a high red brick tower on one side of it. A historic equipment has bee maintained in the mill. A fragment of the mill stone is installed in the the building's façade facing the road with the year of building and the initials of the builder W.v.G. 1887 engraved on it. Currently a hostel is operating in one part of the mill. On the opposite side of the road there is a miller's house which was built in the middle of the $19^{\text {th }}$ century. This building has been reconstructed in the first decade of this century - there is a living space in the roof with a balcony which does harmonize with its historic image.

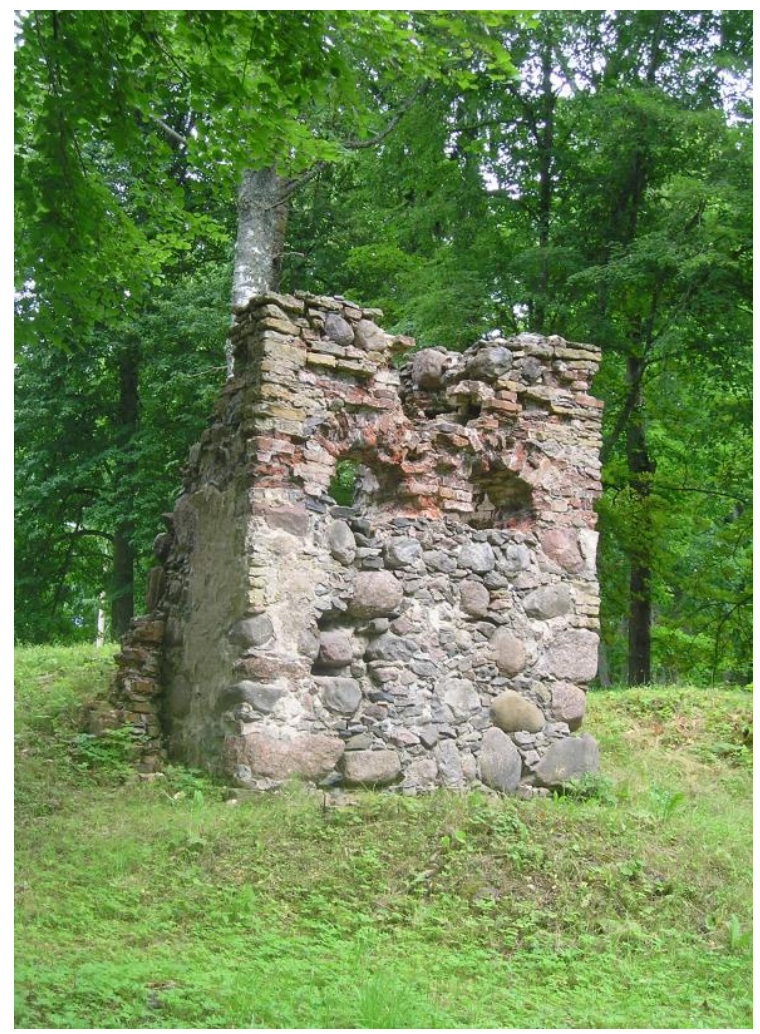

Fig. 5. The remains of the masters' house [photo by the author, 2017]

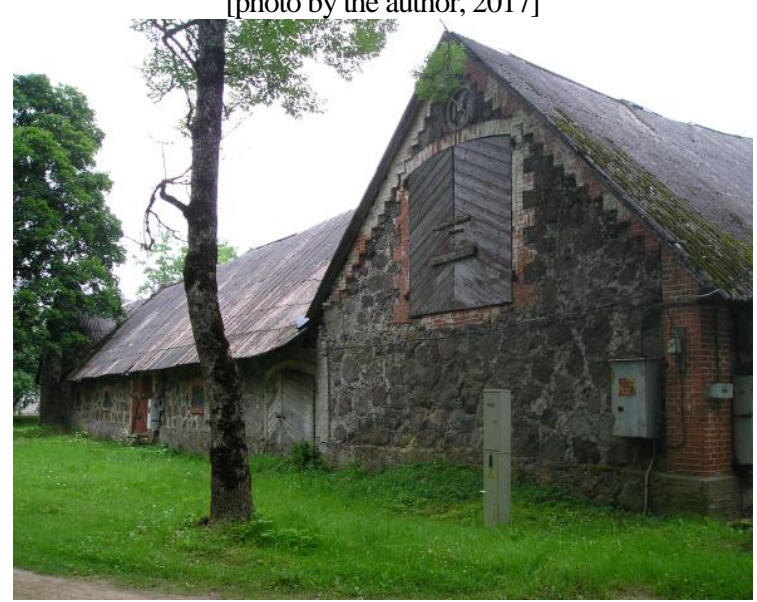

Fig. 6. Enclosure [photo by the author, 2017]

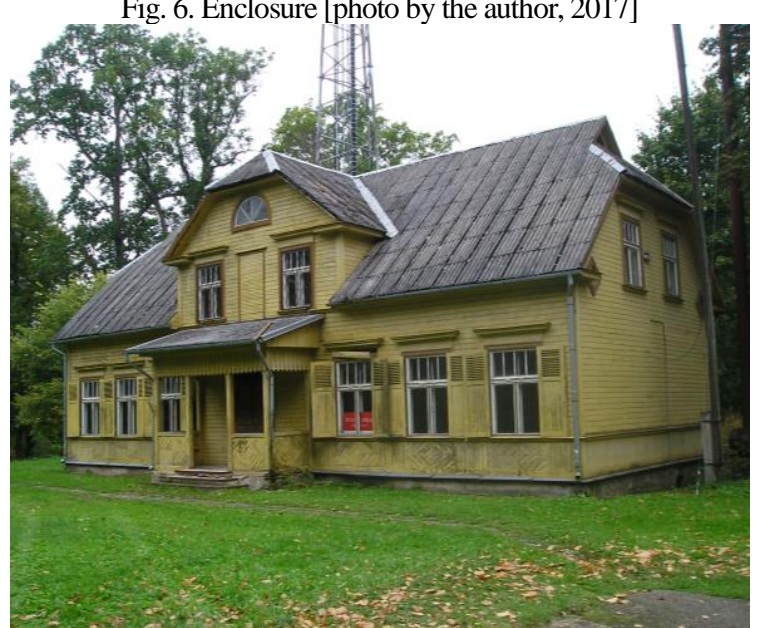

Fig. 7. The summer house, later used as a post-office [photo by the author, 2017] 


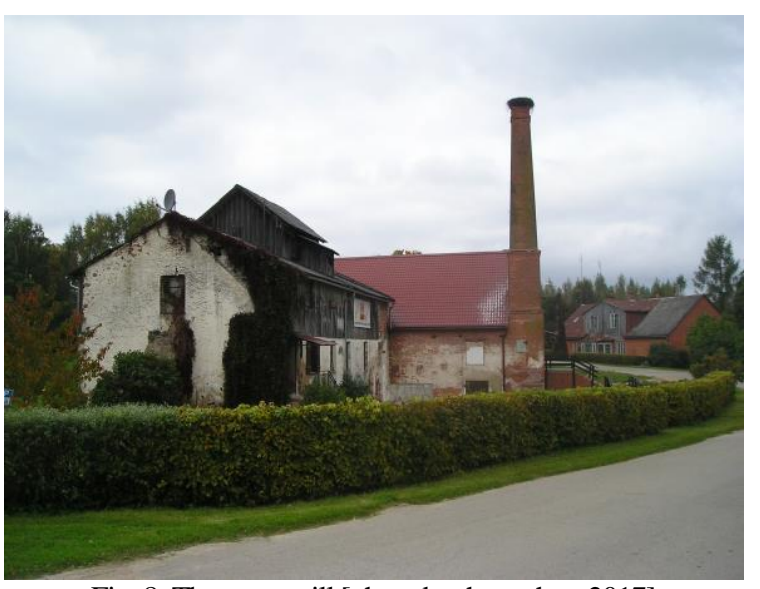

Fig. 8. The watermill [photo by the author, 2017]

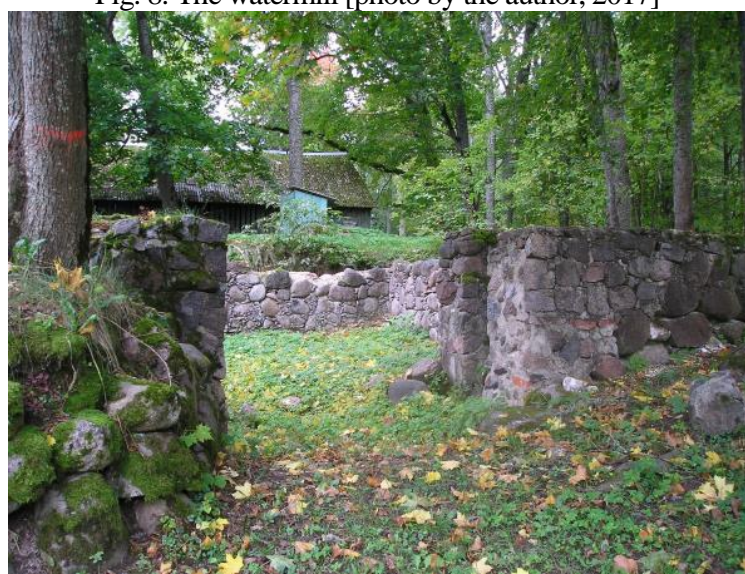

Fig. 9. A farm house with double walls in the cellar [photo by the author, 2017]

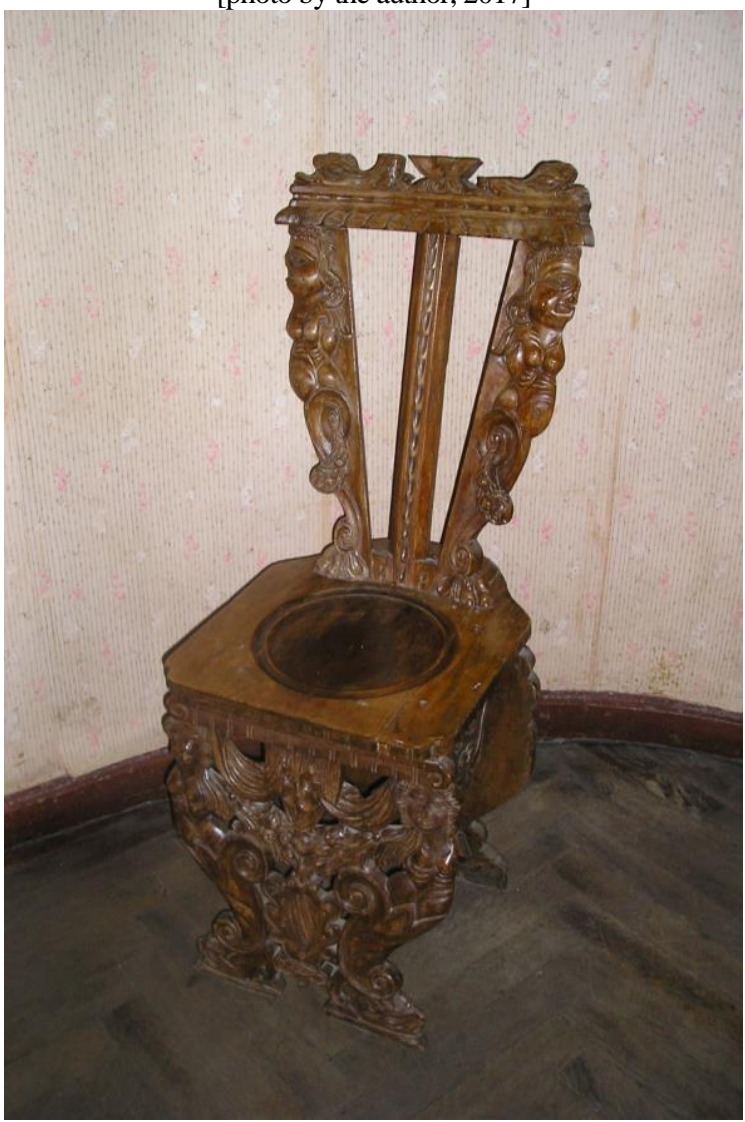

Fig. 10. The chair from Zasa manor, now an exhibit of the Krustpils castle [photo by the author, 2017]

\section{Parks}

The park of Zasa manor is one of the most beautiful, cultivated and lovely places in Selonia. It is about 23 hectares large and its designing began already in the $18^{\text {th }}$ century by Baron von Sass, and it has features of a romantic landscape park. It is often mentioned in various publications that it reminds Gatchina Park of St. Petersburg regarding its composition and structural design. This park is composed of several parts and it has been created gradually from 1766 to 1783 (architect A. Rinaldi) and at the end of the $18^{\text {th }}$ century by architect N. Lvov (Львов). Probably the similarity is seen in the main park, the so-called Castle Park, which combines large lakes with picturesque islands and a lot of small architectural forms. The main motif of the composition here is water. The lakes are located not at the edges of the park, but in the center of it and it is the dominating feature. The surface of the water is seen from a distant view, small bays and streams attract attention from close proximity. In addition, the water surface reflecting plants of a variety of colour shades not only makes the landscape attractive, but also intensifies the impression of a painting and comprehensive space. The surface of the water reflects the sky and the sky itself creates a mysterious depth effect. All of the above mentioned can be referred to Zasa Park. Certain merits of the development and cultivation of this park could be attributed to the Greig family members, in particular to Vasily Greig.

The oldest, currently known information about the design of the park associated with the ponds refers to two land plans from 1924 and 1928 [26]. The configuration of these ponds has not changed significantly to this day. There have been three bridges in the narrow places of the water bodies. It is interesting that at the highway leading to the centre of Zasa on the side of the park in 1928 the water level was raised. In 1967, Latvia's topographical plan showed only few flows, but nowadays this area again has a large water surface. Groups of trees are visible in the distance over it. This water surface with reflections informs us about the expected beauty created by the nature and human hands here.

The park is decorated with several flushed ponds which are connected through the river Zasa which in the park's territory has the name of Dzirnupite. The ponds include the buildings of the estate's centre in the semi-circle. The ponds have acquired names over the time - Yellow, White and Pink Pond. Four bridges are created at the connection points of ponds. In all seasons there are picturesque views on the centre of the estate, the nearby church and the mill. There are several islands in the ponds, and one of them is named Love Island; the name is associated with unhappy love of a local gardener and the owner's daughter of the manor. There is also 


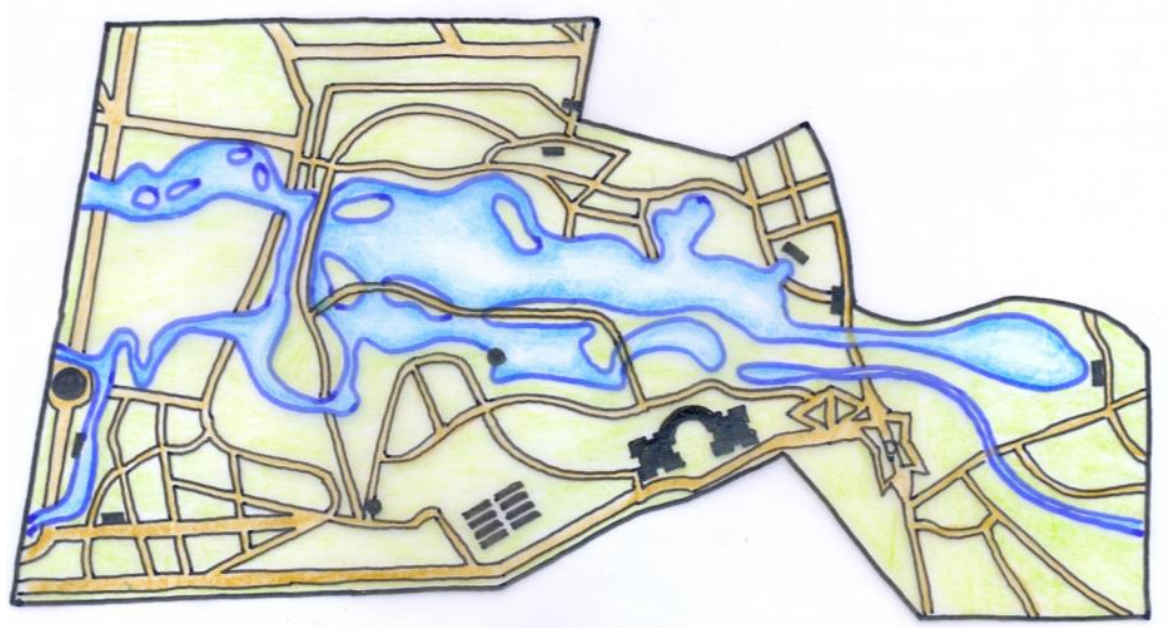

Fig. 11. The landscape design of Gatchina Park [created by the author]

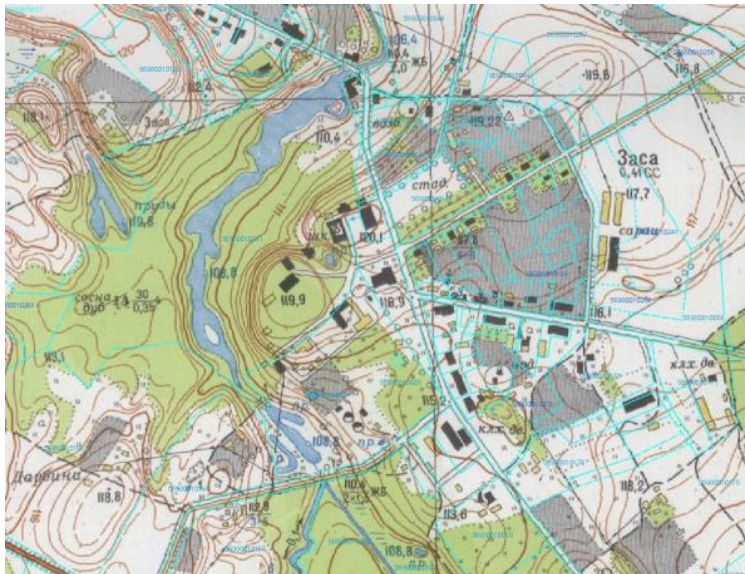

Fig. 12. Topographical plan of Latvia in 1967. An extract. [Latvia State Inspection for Heritage Protection. Monuments Documentation Centre]

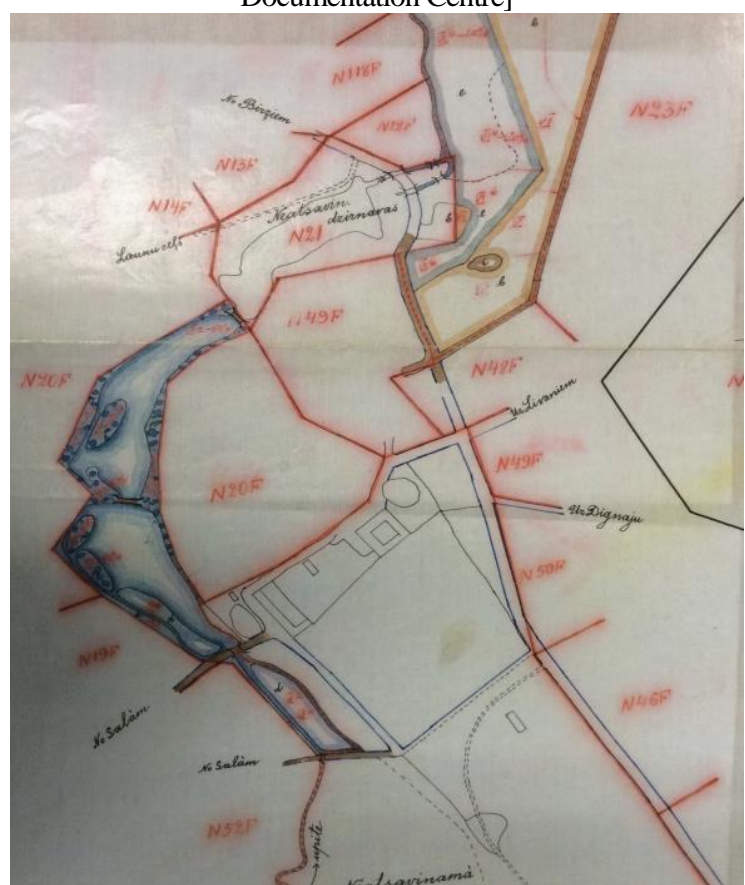

Fig. 13. Division of Zasa estate's farms and the plan of changes in the design. An extract. 1928

[Latvia State Historical Archive, 1679, f., descr. 172., p. 543.]

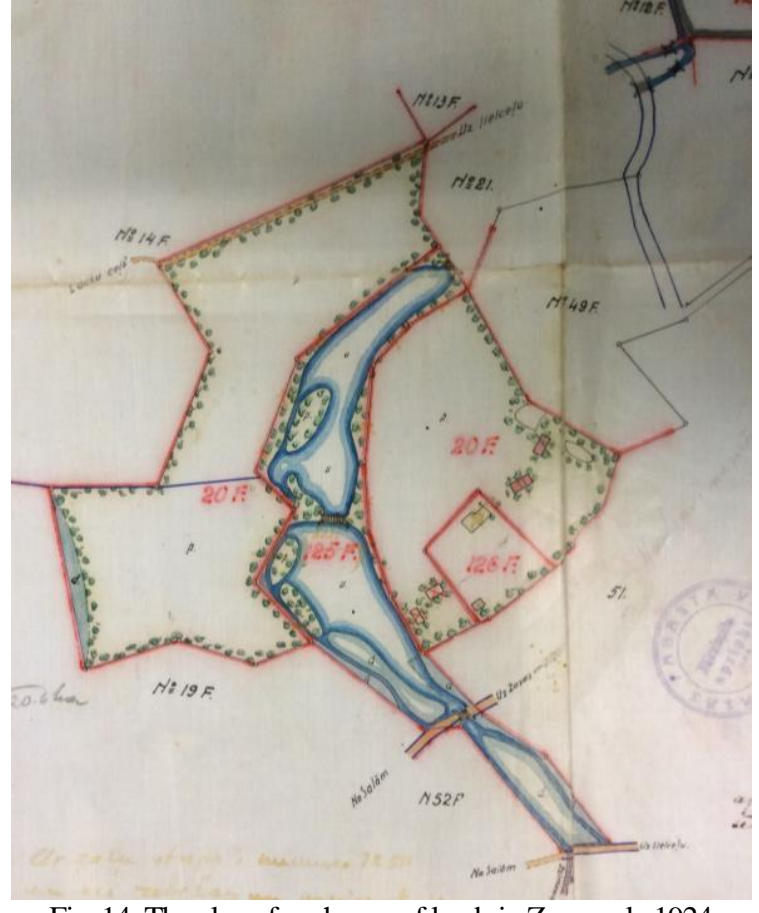

Fig. 14. The plan of exchange of lands in Zasa park. 1924 [Latvia State Historical Archive, 1679., f., descr. 172., p. 543]

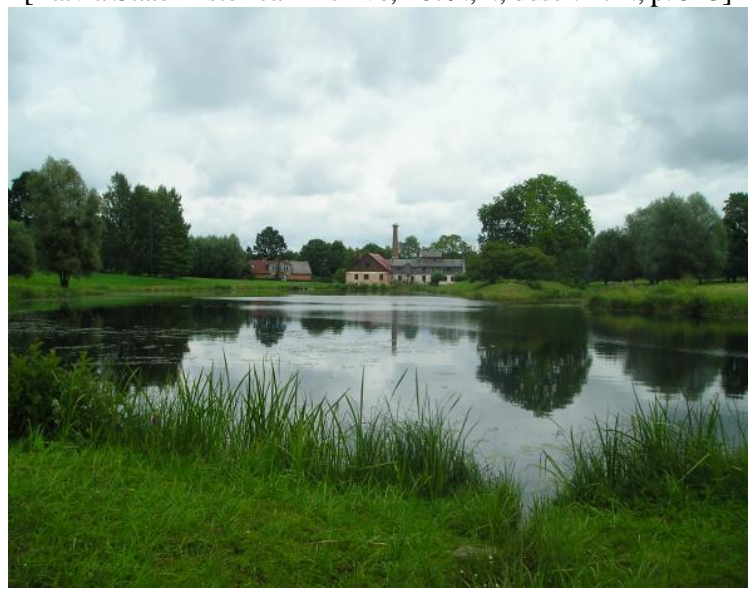

Fig. 15. Park with the watermill [photo by the author, 2017] 


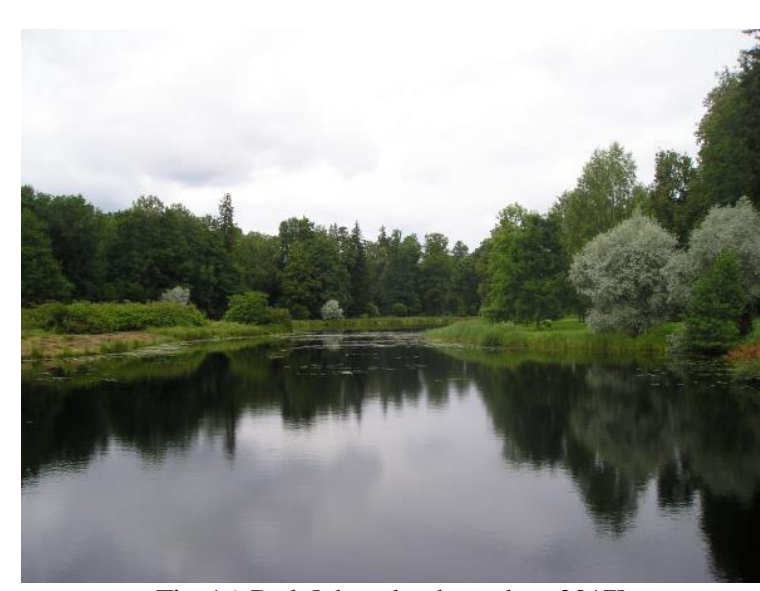

Fig. 16. Park [photo by the author, 2017]

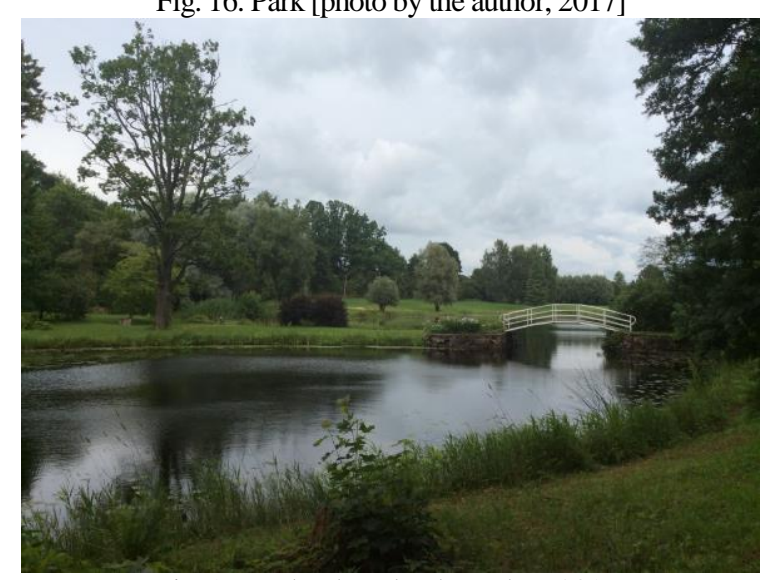

Fig. 17. Park [photo by the author, 2017]

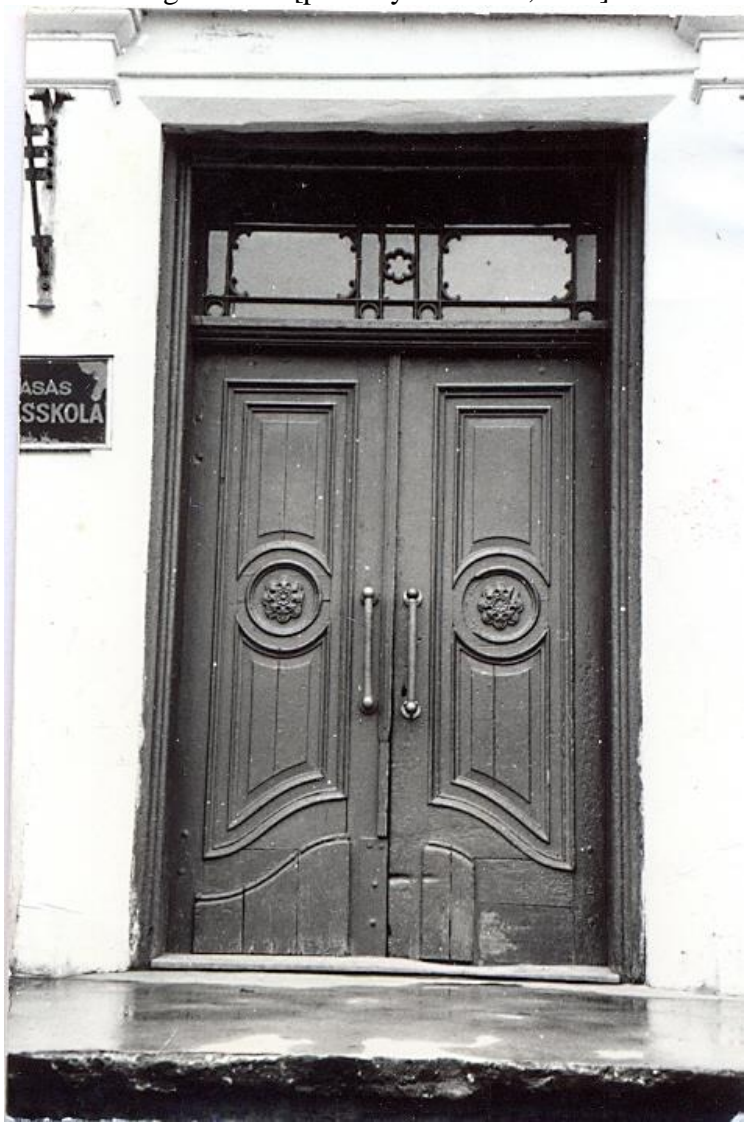

Fig. 18. The main entrance into the secondary school of Zasa [photo by the author,1998]

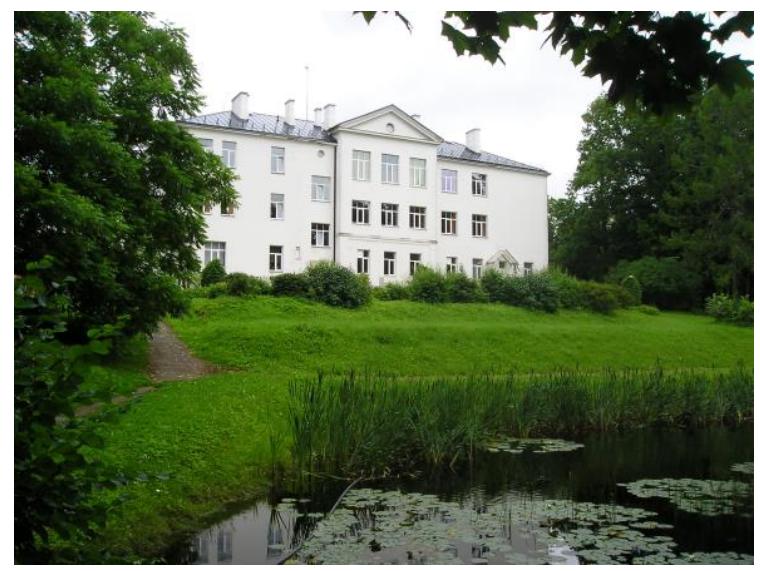

Fig. 19. Secondary school of Zasa [photo by the author, 2017] a divine spring, which was once a worship place of Selonians. There is also a small pond opposite the school. It has a fountain, water lilies, a foliage of trees falls over the pond from one side, the other view is more panoramic. Next to this pond there is another, smaller pond of a rectangular shape.

Vast water bodies creating the pond system play an important role in the atrractiveness of the park. In some places plants occupy areas close to the shore and various coulours are reflected in the water surface. Plants elsewhere are in far distance behind the meadows. The water surface reflects the sky here and individual trees creating the foreground of the distant landscape.

Trees and shrubs are chosen in a variety of colours from dark blue green to silver velvet. They make up both impressively pronounced and gentle water flowing play of shadow and light. The park is also a place of various emotions. Moving across the bridges one has the feeling that lovers meet here frequently and are inspired by the beauty of the surrounding nature. A completely different type of emotions appears on the boat rowing through the park's ponds. Each moment a new view appears with a hidden secret or surprise behind each turn, and one wants to believe that the life also will be interrupted with something new and unexpected.

A particular attention is paid to the species of trees and shrubs from abroad. There are white fir trees, silver willows, black and Weimouth pines, Tunberger's barberry, Cornus Alba plants, and others. As regards caulescent plants, there are mainly moisture-loving species: Sahalin's hydropipers, large bearded bellflowers, low myrtles and others. Besides the ruins of the former old masters' house, on the edge of the pond there is a terrace for rest arranged in the Soviet time with a small pool and a fountain which has not worked for a long time. A little hill on the edge of the pond just opposite one of the islands, the so-called Sugar Hill, is surrounded by centuries-old trees. The stories are told that the owners of the manor used to have coffee without sugar on weekdays and coffe with 


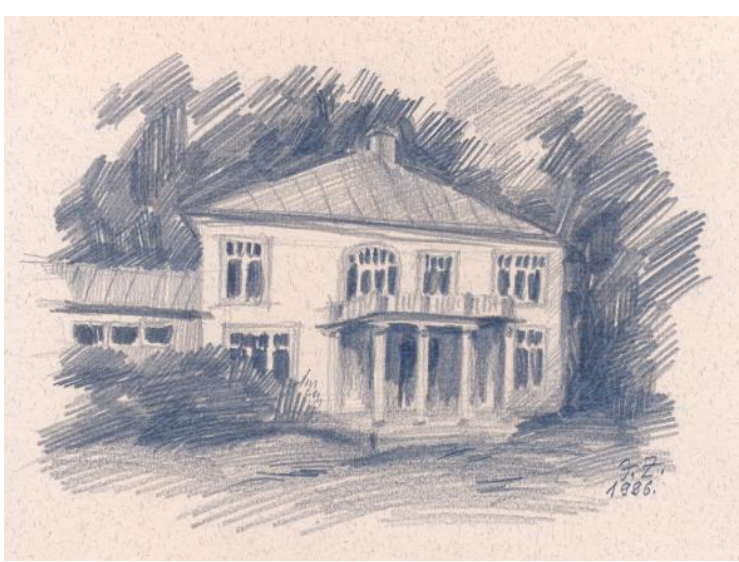

Fig. 20. Stukuls mansion [drawing by the author, 1996]

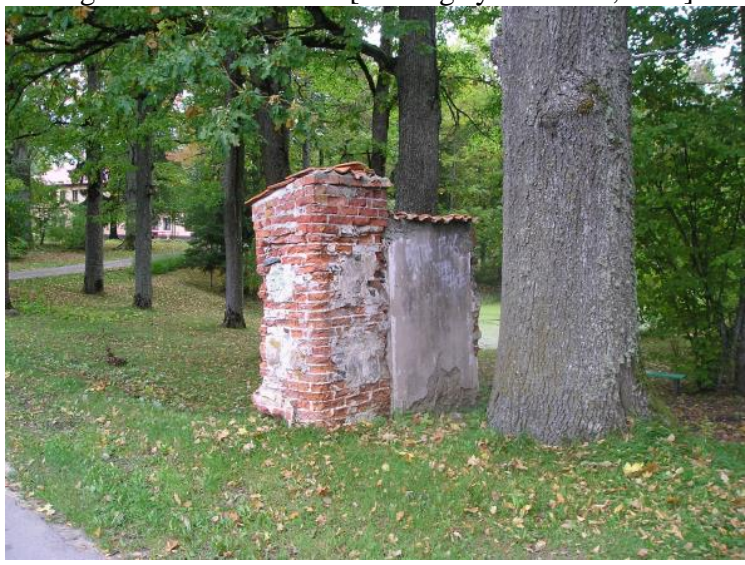

Fig. 21. The fragment of gates from Zasa manor in the park [photo by the author, 2017]

sugar on Sundays. There has been an arbour on the hill. It has been repeatedly restored over time, however, it was burned down in 2007. Two 200year-old linden trees were damaged during the incident. Later the arbour was restored in the shape of a traditional park design and has survived to this day. It has polygonal shape with benches inside and decorative supports. Zasa Park is the place where one would like to come back again and again enjoying its radiant peace and thinking about eternity - and that's just love ...

The old park has had its own continuation in the recent past. On the birthday of V. Stukuls in 1927 , the guests planted a birch grove. Now it is called the Stukuls Grove and the birches are still green. The grove is situated opposite the former Zasa collective farm's petrol station.

Inside the park there is the secondary school of Zasa (1939), which previously had the same outside door leaf construction as the brewery, but now it is replaced by the new impersonal door. Behind the boulder masonry fence the so-called
Stukuls Mansion (the 1930s) is hidden. Its main façade is facing the exit from the park. The building is characterized by the manifestation of the greatness of a wealthy host of his time. It is interesting to note that the Stukuls family photo was placed on the cover of the famous journal "Atpūta" in 1932. Zasa Park was considered to be of a special value in the 1930s and was named as a park to be preserved in many agrarian reform documents. For example, in 1940 the report of the project for the division of protected Zasa Park stated that there was no agreement received to remove the Zasa mill river as a separate object from the park's area [27].

Zasa Park undoubtedly requires further detailed research. However, it can already be argued that this is one of the most historically significant examples of manor landscape parks in Latvia, and it has a remarkable landscape and dendrological quality.

\section{Conclusions}

The last owners of Zasa estate up to the agrarian reform of Latvia were the Greig family representatives. It was bought in the 1860 s by Vasily Greig, whose grandfather and father were admirals of the Russian Navy, well-known personalities. No substantial information about this family has been published in Latvia until now. Some minor articles have mistakes and inaccuracies that are now being corrected. The fate of Zasa manor after the agrarian reform of Latvia is associated with the Stukuls family, who were prominent farmers; their representative Vilis Stukuls was a well-known horse breeder. Stukuls Mansion today expresses architectural manifestations of the 1930s in the design of the central part of manor's estate. The school building of Zasa is a significant example of the building art of the time of the independent Latvian state.

Zasa manor park, as evidenced by the field research, the identification and analysis of literature and archive materials, is one of the most important culture heritage landscape parks in Latvia. It has excellent scenic and dendrological quality. The park has, on the whole, retained its design and spatial structure to this day. The above said allows to make a conclusion that it is necessary to propose the inclusion of Zasa manor park in the List of State Protected Cultural Monuments as a national monument.

\section{References}

1. Brugisis, D. Historisma pilis Latvijā. Rīga: Sorosa fonds Latvija, 1996, 138., 139., 196. lpp.

2. Zarāns, A. Neesam šķirami no savas zemes. Rīga: Zelta grauds, 2003, 157. lpp.

3. Plaudis, A. Cel̦edis pa Latviju. Rīga: Jumava, 2000, 213., 214. lpp.

4. Sakk, I. Läti mõisad. Reisijuht. Tallin: Sakk, 2006, 261. lpp.

5. Zilgalvis, J. Daugavas muižas. 18. gs. - 20. gs. sākums. Rīga: Izglīīība, 1998, 109., 110. lpp., Zilgalvis, J. Daugavas muižas. 18. gs. - 20. gs. sākums. Atkārtots un papildināts izdevums. Rīga: Izglīîiba, 2002, 129., 130. lpp., Zilgalvis, 
J., Muceniece, A. Vēsturiskie dārzi un parki. Eiropas kultūras mantojuma dienas 2007. Rīga: VKPAI, 2007, 62. lpp. u. c.

6. Enciklopēdija Latvijas pagasti. Latvijas pagasti, novadi, pilsētu un novadu lauku teritorijas. Rīga: A/S Preses nams, 2002, 2. dala, 659. - 661. lpp.

7. Diopa, D. Kultūrkapitāla fonds atbalsta Zasas parku. Brīvā Daugava [Jēkabpils], 2008, Nr. 114. Mikanovska, S. Vandąii sadedzina 200 gadus vecas liepas. Jaunais vēstnesis [Jēkabpils raj.], 2007. gada 27. aprīlis., Lielmeža, B. Zasas parks. Brīvā Latvija, 2003, Nr. 33., Rupenheite, I. Zasas lauki. Kur slēpjas zelta kariete un spēkavots. Diena, 1998. gada 7. augusts.

8. Zasas muiža. [tiešsaite] Vietas: Latvijas cel̦edis [skatīts 06.08.2017]. http://www.vietas.lv/objekts/zasas_muiza/

9. Das Inland. Eine Wochenschrift für Liv-, Esth- und Kurlands Geschichte, Geographie, Statistik und Literatur. Dorpat: Heinrich Haakmann, 1846, S. 908.

10. Zasas muiža. [tiešsaite] Vietas: Latvijas celvedis [skatīts 06.08.2017]. http://www.vietas.lv/objekts/zasas_muiza/

11. Управление, охрана порядка, социальные службы в Царском Селе. [unline] Энииклопедия Царского Села [cited 04.08.2017]. http://tsarselo.ru/yenciklopedija-carskogo-sela/upravlenie-ohrana-porjadka-socialnye-sluzhby-vcarskom-sele/

12. Сады и парки Санкт-Петербурга 19 - начало 20 века. Сост. Н. Г. Жукова. Москва, Санкт-Петербург: Центрполиграф МиМ-Дельта, 2004, стр. 70.

13. It is interesting to note that in 1884 the Riga Garden Architect G. Kufalt, who advised the creation of many manor parks in Latvia, Estonia and russia, participated in the International exhibition organized by the Russian Society of Tea and Wildlife. See more: Kāvere, A. Rīgas dārzu arhitekts Georgs Küfalts. Rīga: Jumava, 2007, 73. lpp.

14. http://ru.rodovid.org/wk/ Skatīts 06.08.2017.

15. Latvijas Valsts vēstures arhīvs (LVVA) F. 1679., descr. 172., p. 543.

16. Richter, A. Baltische Verkehrs und Adressbücher. Riga: Im Selbstverlage des Herausgebers Adolf Richter, 1912, Bd. 2., Kurland., S. 631.

17. Valsts kultūras pieminekḷu aizsardzības inspekcijas Pieminekḷu dokumentācijas centrs (VKPAI), lieta Zasas luterāṇu baznīcas kapliča.

18. LVVA F. 1679., descr. 172., p. 543.

19. LVVA F. 1679., descr. 172., p. 543.

20. Stukuls, V. Krustpilieša stāstījums par dzimto novadu, saviem priekštečiem un dzīves gaitu. Madona, 1992, 91. lpp.

21. LVVA F. 1679., descr. 172., p. 543.

22. Bruğis, D. Historisma pilis Latvijā. Rīga, 1996, 138., 139. lpp.

23. Brugisis, D., ibid, 139. lpp.

24. Mašnovskis, V. Latvijas luterāṇu baznīcas. Vēsture, arhitektūra, māksla un memoriālā kultūra. Rīga: Due, $2007,4$. sēj., 423. lpp.

25. LVVA F. 1679., descr. 172., p. 543..

26. Zasas muižas neatsavināmās daḷas un muižas valsts fonda zemes - rezervētās pie neatsavināmās Zasas muižas üdensdzirnavu un atseviški izdalītās daḷas apmaiṇas projekta plāns. 1924., vecākais mērnieks J. Jansons un Zasas muižas saimniecību sadalīšanas un izmaiņu projekta plāns 1928., mērnieks Ed. Laukmanis. LVVA F. 1679., descr. 172., p. 543.

27. LVVA F. 1679., descr. 172., p. 543.

INFORMATION ABOUT AUTHOR:

In 1979 Jānis Zilgalvis graduated from the Faculty of Architecture of the Riga Technical University. In 1990, he defended his doctoral thesis on the subject of the manor architecture of the second half of the $19^{\text {th }}$ century and the early $20^{\text {th }}$ century. Since then, he is the Head of the Architecture Department of the State Inspection for Cultural Heritage. Since 2012 - a full member of the Latvian Academy of Sciences. Over 180 scientific and popular scientific publications and 18 books (some co-authored). The main lines of the research - the manor architecture and cultural history, sacral architecture, protection of cultural heritage.

Kopsavilkums. Par Zasas muižu (Weessen) ir rakstīts l̦oti maz, gan 19. gadsimtā, gan mūsdienās. Lai ieviestu skaidrību šīs muižas īpašniekos, parka veidošanā un īpašuma likteņos tika veikta literatūras un interneta avotu, kā arī arhīvu materiālu izpēte. Objekts vairākkārt apsekots uz vietas. Laika posmā no 1644. līdz 1787. gadam muiža piederēja fon Zasu (von Sass) dzimtai. Vēlāk īpašnieki mainās. Ir zināms, ka 1846. gadā mūžžỉā aizgājis bijušais Talsu (Talsen) apriņ̧̧̧a tiesnesis un Viesienas muižas ķ̄ilu turētājs Vilhelms fon Rummels (von Rummel). Pēcāk muižā saimniekoja, domājams, viņa dēls, arī Vilhelms.

Ap 1865. gadu ieḳīlāto muižu nopirka Vasīlijs Greigs (Greigh). Š̄is dzimtas pirmsākumi meklējami Skotijā. V. Greiga vectēvs bija plaši pazīstamais un slavenais Krievijas flotes admirālis S. Greigs (1735-1788). Viens no S. Greiga dēliem bija Aleksejs Greigs (1775-1845) - jau minētā Zasas muižas īpašnieka Vasīlija Greiga tēvs. Viņš bija ievērojams Krievijas flotes admirālis un viņa krustvecāki bija Katrīna II un grāfs Aleksejs Orlovs. Vasīlija Greiga brālis bija Samuils Greigs, Krievijas armijas ǵenerālis un finanšu ministrs (1878-1880). V. Greigs 1859. gadā bija precējies ar Mariju Kumingu (1837-?) un laulībā dzimuši četri bērni. Vasīlijs Greigs miris 1902. gadā. Muižu mantoja dēls Aleksejs, kurš agrārreformas dokumentos minēts kā pēdējais īpašnieks ar norādi, ka muižas neatsavināmās daḷas tagad pieder Nikolajam Greigam, acīmredzot Alekseja dēlam. Štāba rotmistrs Aleksejs Greigs kā muižas īpašnieks minēts arī Rihtera 
Adresu grāmatā. Agrārreformas rezultātā lielākā daḷa muižas zeme tika sadalīta 88 jaunsaimniecībās. Noteiktas platības tika atstātas un korig̣ētas arī sabiedriskām vajadzībām. Muižas centra saimniecību kopā ar ūdens un tvaika dzirnavām 1924. gadā no muižas īpašnieka I. Stukuls. Pēc viṇa nāves saimniecību mantoja dēls Vilis Stukuls (1909-1996), ievērojams Latvijas zirgkopības speciālists. 1921. gadā muižā atradušās divdesmit piecas dažādas ēkas un būves. Šodien atlikusī muižas centra apbūve grupējas ap taisnstūrveida pagalmu, kura aprises vēl nojaušamas. No senākās kungu mājas saglabājušās tikai drupas. 19. gadsimta otrajā pusē celta jauna kungu māja, kas nodedzināta 1905. gadā. Šī nelielā ēka attāli atgādināja skotu izcelsmes Krievijas arhitekta Ā. Menelasa (A. Menelas, Menelaws, 1747-1831) Krievijas caram Nikolajam I celto kotedžu jeb lauku māju Pēterhofā. Raugoties uz senākās kungu mājas drupām, pa labi redzama neliela koka ēka. Arī tā celta kā Greigu vasaras māja pēc iepriekšējās nodedzināšanas. Šo pagalma malu papildina paliela divstāvu ēka bijusī klēts. Saimnieciskajai apbūvei pieskaitāmas arī ūdensdzirnavas (19. gs.).

Zasas muižas parks ir viena no izkoptākajām un jaukākajām vietām Sēlijā. Tas ir aptuveni 23 hektāru liels un tā veidošana uzsākta jau 18. gadsimtā - baronu fon Zasu laikā un tam ir romantiska ainavu parka iezīmes. Bieži vien dažādās publikācijās minēts, ka tas pēc savas kompozīijas un struktūras atgādina Gatčinas parku pie Pēterburgas. Zasas parku rotā vairāki uzpludināti dīķi, kurus savieno cauri tekošā upīte. Dīķi muižas centra apbūvi ieskauj ielokā. No tiem visos gadalaikos paveras gleznaini skati uz muižas centru, tuvumā esošo baznīcu un dzirnavām. Dīḳos atrodas vairākas saliṇas. Liela uzmanība parka izveidē pievērsta svešzemju koku un krūmu sugām.

Parka ielokā atrodas jau minētā Zasas vidusskola (1939). Parka vienā malā, aiz laukakmeņu mūra žoga paslēpusies t. s. Stukuḷa savrupmāja (1930. gadi). Zasas muižas parks, kā liecina tā izpēte uz vietas, literatūras un arhīvu materiālu apzināšana un analīze ir viens no kultūrvēsturiski nozīmīgākiem ainavu parkiem Latvijas muižās. Tam ir izcilas ainaviskās un dendrologiskās kvalitātes. Parks kopumā saglabājis savu plānojumu un telpisko struktūru līdz mūsu dienām. Nemot vērā minēto, nepieciešams ierosināt Zasas muižas parka iekḷaušanu Valsts aizsargājamo kultūras pieminekḷu sarakstā kā valsts nozīmes pieminekli. 


\title{
The contextual search in the landscape space of the school and manor building
}

\author{
Lolita Hercoga, Aija Ziemeḷniece, Latvia University of Agriculture
}

\begin{abstract}
The research deals with the adaptation of the historic manor parks to the needs of schools. In the past hundred years since the founding of schools in the old manor palaces or the lords' houses, a new functional load is brought not only into the historic buildings but also in the old manor park. Most often it is attributable to destroying of the compositional structure of the park, creating a new path network, areas, and individual elements that are not subordinated to the historical sight lines and the structure of the landscape space. This includes important criteria not to lose the scale of the historic parks and the conformity of the stylistic trends of the 18th and 19th centuries. During the last hundred years, only some of the manor parks have undergone the landscape study and development of the documentation but due to the lack of funding the project is not implemented. This has contributed to the creation of separate zones in the manor parks with a random character, which further adds to the lack of professional expertise in the maintenance of the park. A large part of the work to be done will fall on the shoulders of the local government or private owners. Considering the statistics that the number of schools in rural areas runs low, it is possible that the historical legacy comes into the hands of conscious owners, who will devote considerable efforts in the maintenance of the old parks.
\end{abstract}

Keywords: historic manor parks, landscape space, criteria, compositional structure

Introduction

From the 1920s, when the political authorities in Latvia changed, the significance of the manor building ensembles has also changed. Manor buildings and parks have acquired a new function, which has contributed to their use nowadays. With activation of the lifestyle and the needs of the society, it is readable in different innovations in the neighborhood of the manor palace and the area of the park. The changes necessary for the use of modern parks can be observed in the parks in Latvia, in neighboring countries, and in Western Europe [6]. In a number of places, the new elements fully complement the historic building but they often bring disproportion, not respecting the cultural and historical context of the place both stylistically and in terms of location. Although, over time there came functions that facilitate the use and management of the area there is still serious work to be carried out in order to find a balance between preservation of the cultural and historic heritage and innovations of the modern technologies.

One of the most difficult tasks is to balance the mandatory requirements of the training program of the school as an educational institution with its location in a historic manor building.

The time of the agrarian land reform in Latvia from 1922, provided adaptation of the manor buildings for various uses - for the school, sanatorium, people's house, union, dairy, county parish house, poorhouse [1].

Most often the lord's manor house or the palace was adjusted to the school by changing planning of the school building and extensions to the building. According to the data of the Association of Latvian Palaces and Manors, as of 2009 in the manors of Latvia, there were 109 schools [4]. As of 2009, in the manor centers of the national significance operated 17 manor schools, out of them until 2017, schools still are located in 13 palaces (Beḷava, Dzelzava, Ezere, Jaunmuiža, Laidi, Marinzeja, Naukšēni, Ozolmuiža, Pope, Remte, Vandzene, Vilce, Zalenieki).

The manor buildings and parks form the cultural and natural heritage, which in several places is positioned as a tourist site. It is visited and used by school children, local residents, and visitors. To summarize the above, the research aims to examine the development of the area of the school and the manor ensemble in the process of the preservation of the quality of the park.

The assignments of the research concern the analysis of the territories of the park, evaluating the placement of the school activity zones there, to study each of the zones in detail, analyzing the sight points, the distance of the historic tree groups from the sports areas, understanding the compliance of the scale and proportions in specific park locations.

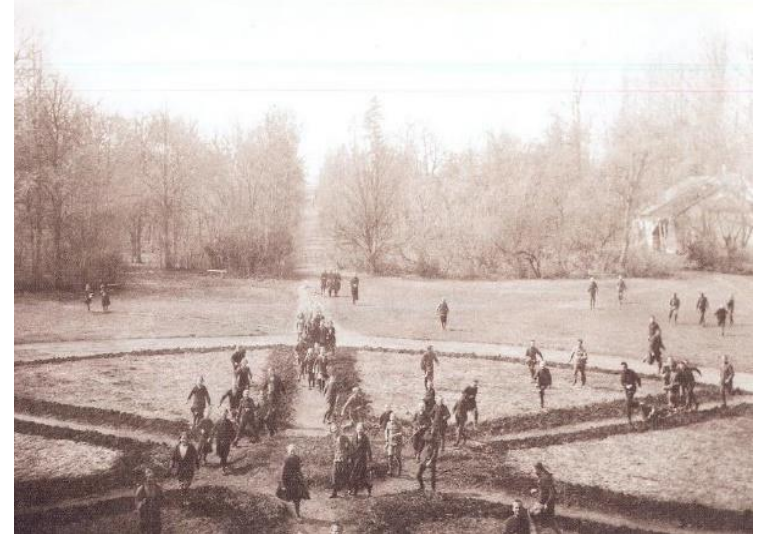

Fig. 1. The park of Svitene Palace. Around 1920 [2] 


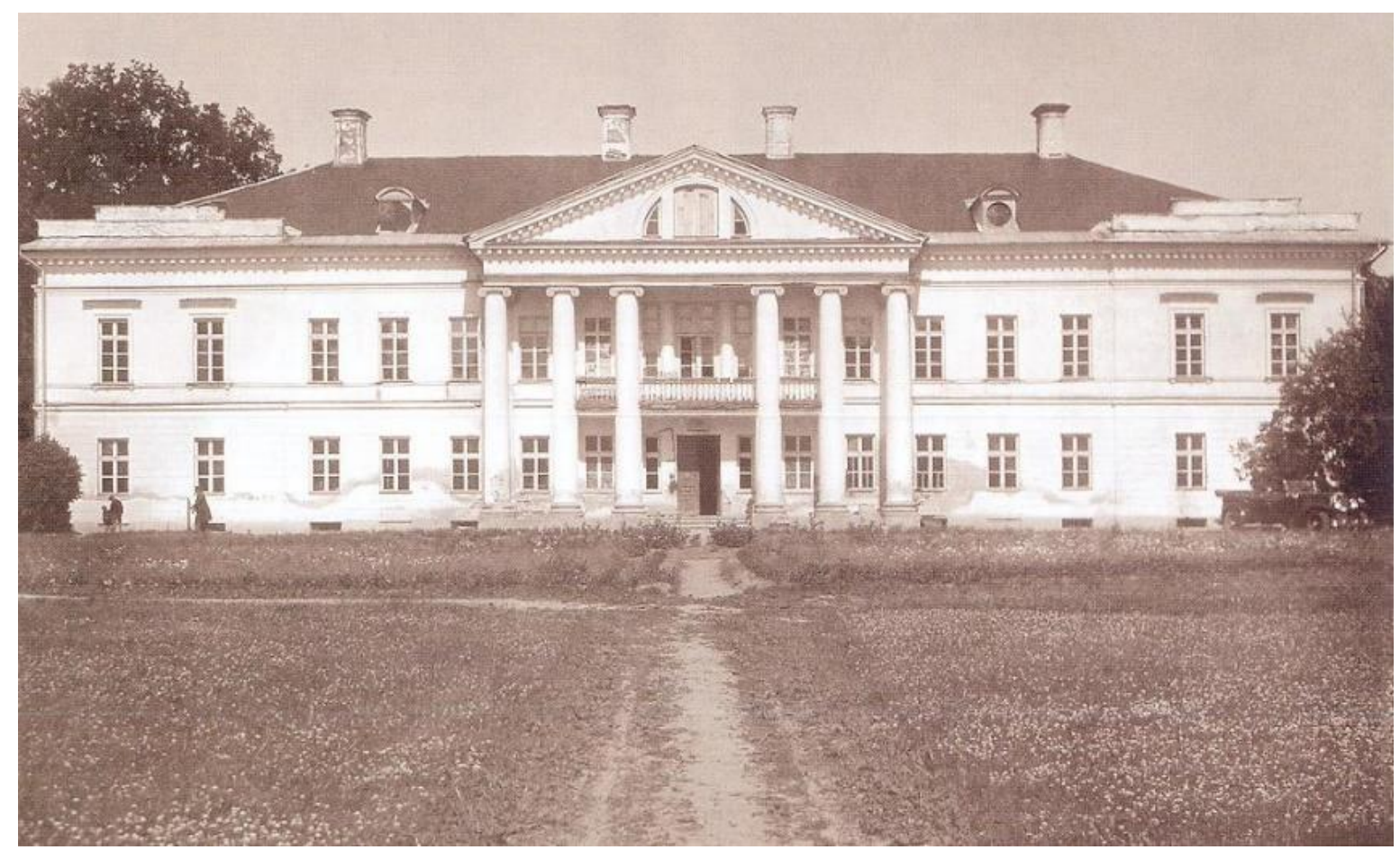

Fig. 2. A view to the glade of the front courtyard from Svitene Palace.1930 [2]

\section{Materials and Methods}

Since the 1920s, the school building in the historic manor building affects not only the buildings but also the park's area, in which sporting areas, green classes, and small summer stages with spectator places are located. Most often, they served as a school-based activity center in parish centers, bringing together locals in a picturesque shady park on summer evenings. It encouraged the village people to meet at feasts and in traditional events, which is especially true in the 1950s - 1980s. The arrival of a new functional load in the park consisted of the development of a new infrastructure - access roads, parking lots, fireplaces, floorboards or asphalted areas for the dance area, summer pavilions, terraces, enclosing plantations, fencing, toilets, storage of waste containers, etc..

The research is based on the comparative method, based on a card materials, photo fixations, architectural and historical research materials, and the exploration of parks in nature. For obtaining the comparative data in the study, in the exploration of the manor parks a ready-made landscape inventory questionnaire is used, which reflects the current state of the landscape space in the manor building and the parks. The landscape inventory questionnaire is structured in four sections: the general data, the visual aesthetic quality of the landscape, education, tourism, and recreation.

The general data include information about the location of the manor, the name of the current school, and the time of its construction in the manor building ensemble. The creation time of the manor park and the park area are fixed.

The visually aesthetic quality of the landscape includes a study on the assessment of the current situation of the elements of the composition forming the structure of the palace and the landscape space of the park, and the assessment of new landscape elements in the context of the cultural history of the site and the modern functional meaning.

Education represents fixed landscape transformation processes resulting from the change of functionality of the lord's house. The schools perform the educational function in the historical building of the manors, in their surrounding areas, and parks.

Tourism and recreation include the cultural and historical heritage that is positioned as a tourist attraction by carrying out surveys, whether the required infrastructure is provided for leisure facilities in the park. It is particularly important to apply it to the recreational attraction of the local population. The survey of the park was carried out from September 2016 until November 2017.

\section{Results and Discussion}

The surveyed schools are located in three Latvian regions: in Kurzeme - six, in Vidzeme five, and in Zemgale - two. In the historic manor building, schools of a different level of education operate - elementary schools, primary schools, the social adjustment institution, the commercial and craft high school. The first schools in the manors 


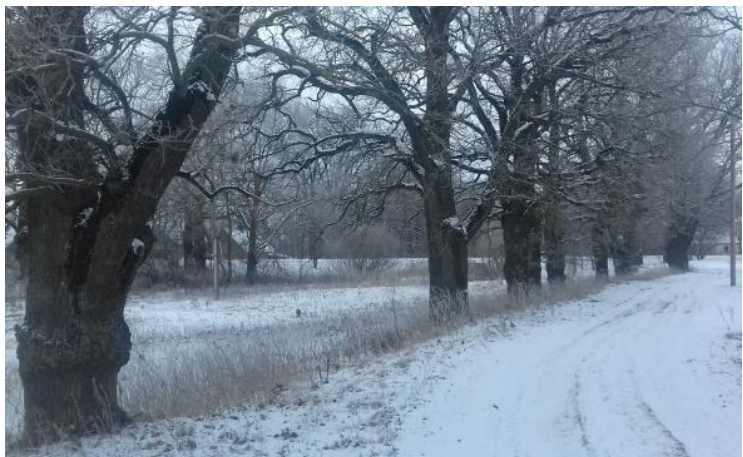

Fig. 3. The oak alley to the farmhouse [photo by A. Ziemelniece, 2017]

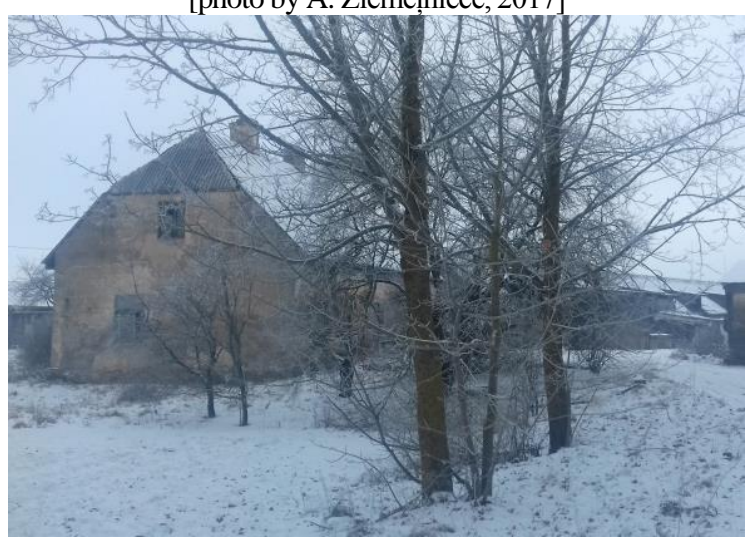

Fig. 4. The farmhouse of the Manor [photo by A. Ziemelniece, 2017]

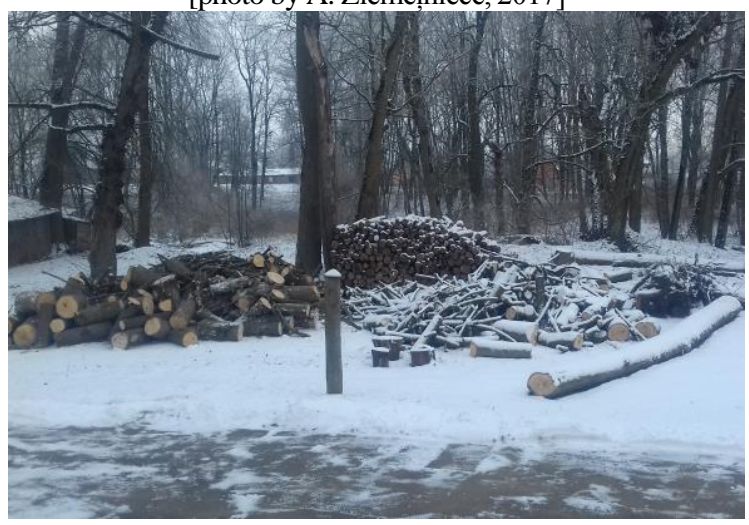

Fig. 5. View from the manorhouse to the park

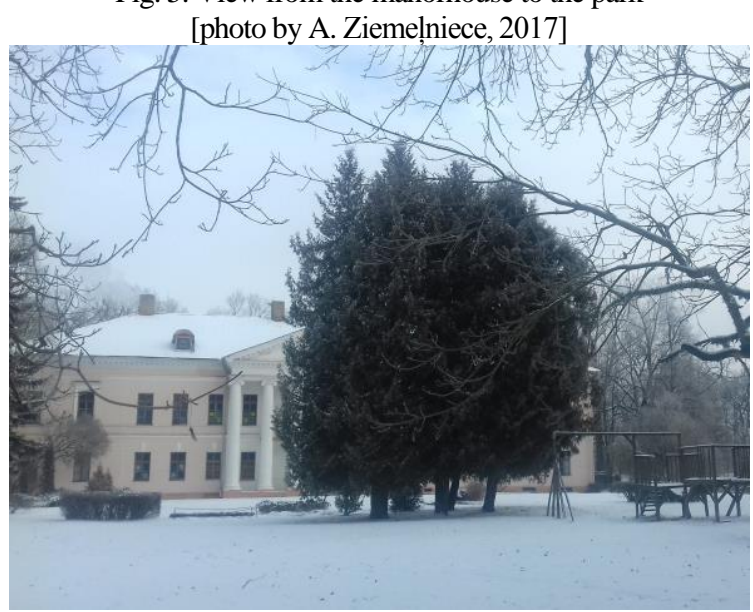

Fig. 6.View to the manorhouse [photo by A. Ziemeḷniece, 2017] date back to the $20 \mathrm{~s}$ of the $20^{\text {th }}$ century, when in Latvia the agrarian land reform started, taking away the manor building center and the agricultural land belonging to the German nobility. Most often, the center of the manor was adapted to the needs of the school. A hundred years have passed since the time of the above reform and in many lord's houses schools continue to operate. During this period, the park nearby to the manor building is adjusted to the school sporting area, so bringing in a new feature in the park. This solution is acceptable as in the world experience there is the transformation of a definite space of the park, bringing in an additional functional load. It only requires a careful and thoughtful solution to the scale, position, and the material used, and a random character is not acceptable. The finely polished compositional structure of every historical park is sensitive to unwisely arranged new paths or areas that may affect the compositional integrity of the park. The surveyed manor or school parks are arranged in the $60 \mathrm{~s}-70 \mathrm{~s}$ of the $18^{\text {th }}-19^{\text {th }}$ centuries, and they are older than 150 years, so creating a very strong historical landscape space, visually easy to understand. Studying Latvian manor or school parks, overlaying of the economic activity of the last century is also apparent that is alien to the historical identity of the park. It is most often attributed to the central glade of the front courtyard. Historically, the view of the lord's house from the driveway carried out a representation function. The sight lines were constructed open, without tree plantings in the circle of the front courtyard, so that the lord's manor house could be seen from a distance. Currently, the open view of the palace remains only to three of the surveyed sites. This is explained by the Latvian Government's decision made in the 20 s of the $20^{\text {th }}$ century, which intended to hide the heritage carried by the Baltic German culture. Especially quickly this was done with the disruption of the main sight line for the front courtyard, planting a dense line of thujas, spruces or oaks in front of the palace. A vivid example is Svitene Palace (the school building), Kaucminde Palace (the household school), etc. $[2 ; 3]$. The recovery of the historical form of the lord's house or the front courtyard of the palace from 1990 is progressing very slowly. Mostly, this is true for trees, planted in the center of the driveway circle. This is due to the emotional surge, as it is painful to cut almost 100 years old trees in the center of the front courtyard. It is similar to the groups of ornamental plantings not matching the scale and flower beds, created in decades but the form creation of the flower beds violates the common architectural stylistics of the building. The back facade of the lord's house was typically 


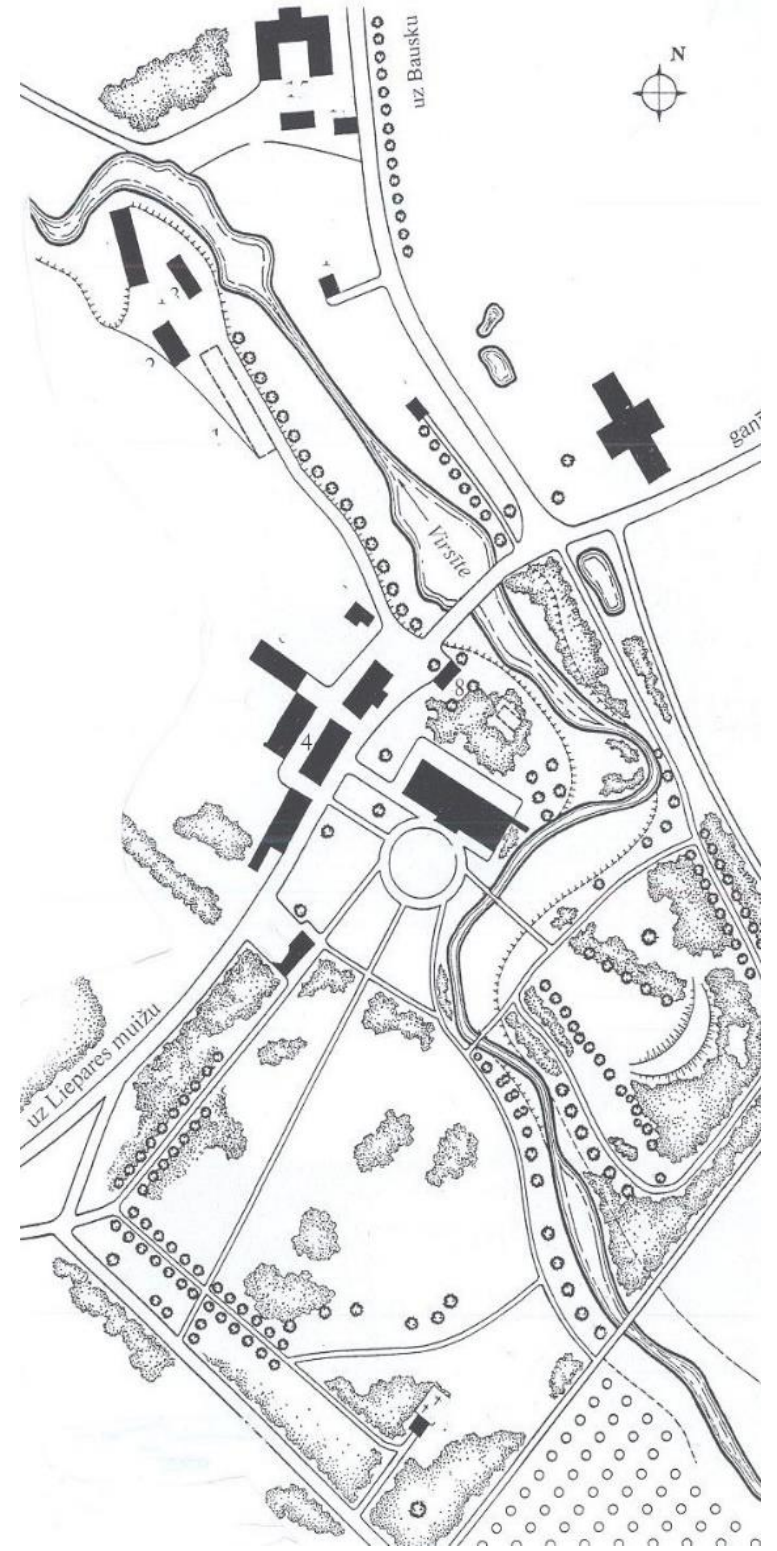

Fig. 7. The park of Svitene Palace. Around 1920 [2]

made more intimate and it was associated with the part of the park in the center of which a glade was located on the longitudinal axis. Closer and further groups of trees, soliters, water elements, architecture in small forms (for instance, a vase, a pavilion), as well as a small area of activities could be viewed. Four palaces surveyed in the course of the research open up an expressive view of the park, which is enriched by different dimensions of the sight lines of the park and the dendrological peculiarities of the groups of trees.

From Laidu Palace and the manor palaces of Vilce, the sight lines lead to well-exposed sight lines, which include separate groups of the historical tree plantations. The glade of Naukšēni Manor includes the natural landscape of the river Rūja. The lord's house of Pope Manor forms a picturesque link of the central glade with the pond, behind which there is the old hunters' lodge.
Only the mystery of the central glade is broken by the school sporting area, obsolete, bright metal gym elements, industrial standard fencing, new plantations disproportionate to the scale, closely built a high rise residential building, a shed for wood. In the late autumn, in the park of Remte Manor, the park pavilion is noticeable in the far sight line.

A school territory is an important place for patriotic upbringing. Therefore, in front of several lord's houses after 1990 memorial marks are placed in the deportation places or for the occupation victims (Remte Palace). This action has initiated conversion of the most picturesque manor ensemble sites to a political struggle "altar". After the survey of the above parks, memorial sites are arranged in four parks.

Svitene Palace with the park can be mentioned as a bright example of the adjustment of the historic lord's house and the park (the primary school by 2016). The park as a beautiful one is already mentioned in 1846 during the visit of J. Doering. Since then, the trees have been grown older. The park compositionally consists of several landscape spaces. Until the start of the $20^{\text {th }}$ century, the front courtyard historically formed a widely transparent sight line, where from distant sight lines the palace was visible [2]. Currently, the southern part of the sight line reminds a city-type square. At the western edge of the sight line near the road the gardener's house. Today, the mentioned sight line is lost. Researching the old tree planting sites, it must be concluded that there had been walking paths along both river banks with romantic sight lines. In the southern part, the sight line is concluded by a transverse axis, which is formed by a linden alley, which leads to the crypt of the barons.

On the southeastern side of the glade, there are the scenic banks of the river Viesite, which are joined by one small bridge opposite the palace. The left bank of the river slope at the palace forms a link to the park's part, that contrary to the wide and light glade of the front courtyard forms a pleasant shading during the scorching summer days. Opposite the path - the historical place of the glade where for the school needs a sporting area with asphalt cover is arranged.

The compositional structure of Svitene Park is changed not only by the time of the political games but also by the demands of the Soviet time according to the rational disposition of the engineering structures. This is attributable to the position of the water tower in the area of the front courtyard, not respecting the historic values but emphasizing technical issues of household nature as the main ones. 


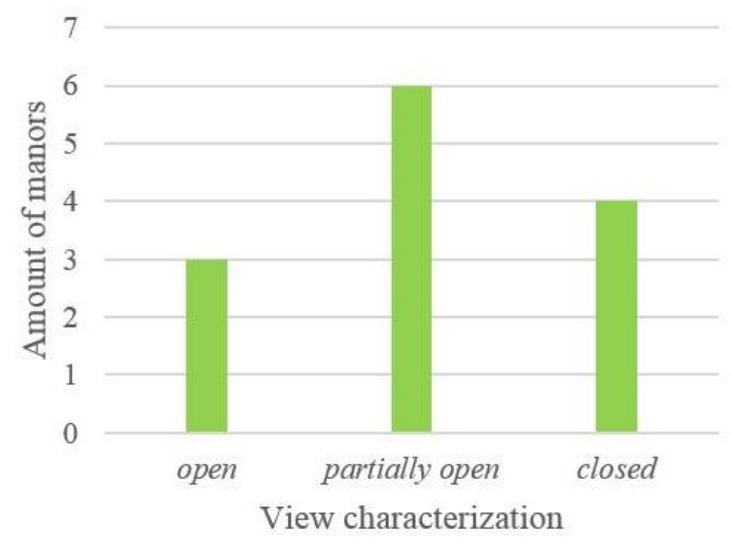

Fig. 8. The description of the representative view of the manor palace [created by the author]

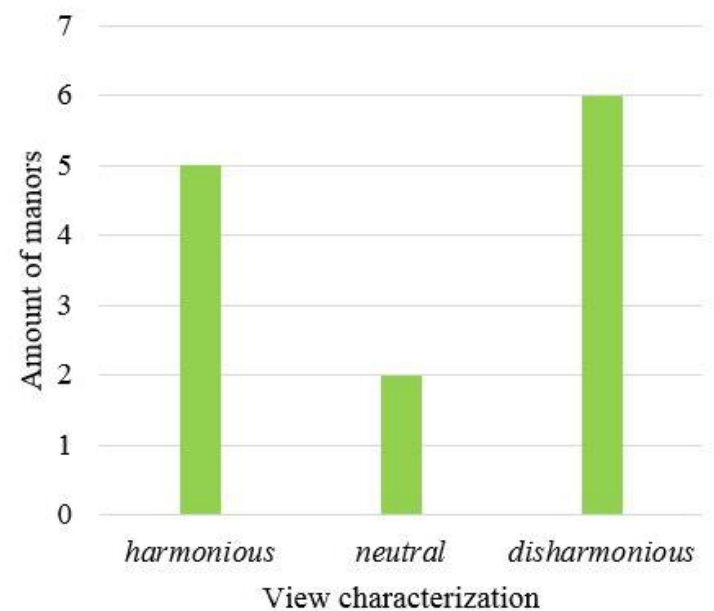

Fig. 9.The assessment of the sight to the central glade of the park [created by the author]

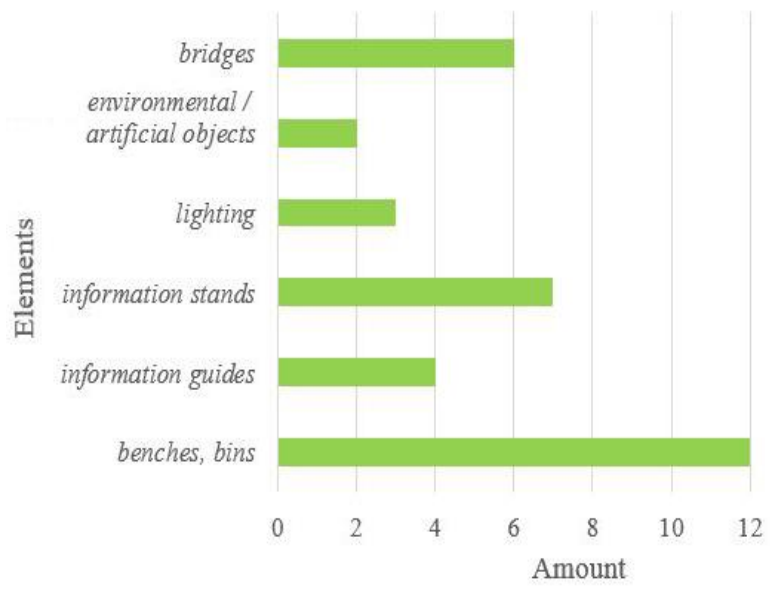

Fig. 10. The new facility elements of the park [created by the author]

The expressiveness of the sight point in the areas of manor parks is affected by the overall nature of the construction of the park:

- The landscape space of the park and the glades are formed by groups of trees and bushes;

- The groups of trees and bushes do not constitute a distinct landscape space;

- The park is transparent, its structure is primarily determined by the trees.
Of the surveyed parks, in eight parks the structure of the landscape space of the park is readable which is formed by glades and plantings. Due to a wrong management, four parks are too groomed or have become dull, as sight lines with evenly correct trunk rhythm of the trees have developed in the park.

In each of the parks included in the research, any of the elements of water are met (a river, pond, lake, spring, ditch, wetlands, an island) which brings the intrigue and mystery in the park. In ten of the surveyed parks, the land surface is flat or moderately undulated, therefore the importance of the plantings in the creation of the landscape space of the park is growing.

From the historic plantation forms, in eleven of the surveyed manors alleys are located. Circular plantations (around the former arbor) are identified in three parks. It should be noted that the topographic measurement and the inventory of the woody plants could reveal yet so far unidentified circular or arc-type plantations. Assessing the quality of the new plantations of the parks, it is concluded that the plantations appropriate to the scale of the site are met - in four parks, partly appropriate quality - in five parks, and an inadequate compositional character - in 5 parks. The protection of the new plantations can be observed in 3 parks.

The small architectural forms are little preserved. Road guidance posts of stone are found - in seven parks, in Ezere Park - foundations of a pavilion have survived. In the park of Remte Manor, a vase podium, torment chamber, grotto, hunting tower, and the pavilion columns can be found. From the visited parks, the small forms of the historic architecture of parks were not found in five of the visited parks.

In the school parks for walks included in the research, both paths and the ground vegetation are used. Six of the surveyed parks have a general path network. A partial path network has remained in four parks but in three parks, the path network does not exist. Considering the compliance of the access road to the palace and the cover of the park's paths with the historic place, in ten manors it is to be assessed as partially adequate. The dominant cover type is asphalt or a concrete pavement.

In the parks, new facility elements are installed benches and garbage bins, signs, billboards, illuminations, environment/art items, small bridges. Only in three parks, the design of new facility elements is judged as appropriate for the historic site, others - of an inadequate quality. The new construction volumes of an economic character - in 12 parks, which have arisen in the post-war years, in terms of the architectural form are of low quality (Fig. 10). 
The new facility elements are fixed for educational activities in the school or the old manor parks - such as benches with Latvian characters in outdoor classes and informative educational elements, such as the Latvian and Latin name of the tree nearby it. For sporting activities, in all the surveyed parks a stadium is built, in 10 parks - gym equipment is placed and in 12 parks-sports playgrounds are installed (for basketball, volleyball, tennis, etc., games). The sporting activity areas are equipped near the lord's house (palace). They can be reached in a very short time, but judged as a degrading element of the cultural landscape. Children's playgrounds are installed in 7 parks behind the manor palace or sometimes next to it. The infrastructure necessary for school activities is focused nearby the palace, the landscape space of the park is less used.

For the promotion of tourism and recreation infrastructure near the schools or the historical palace, informational elements are placed that help the visitor to find new information and navigate in the space. Reference stands were located in 6 parks, in turn, a descriptive planning of the park is located just in 3 parks, informative references - in 5 parks. Near the manor palaces, where the tourist information is located, it refers to the manor ensemble, the palace, the baronial family. A few lines are sometimes found about the parks, although they have the potential to become just as important tourist attractions like the palace, making it possible for tourists to stay longer at the site and to get a wider picture of the manor palace and its surroundings. In the park, the local population is brought together by the stages, found in 7 parks. The campfire site is located in 4 parks but the picnic site - in 8 parks. A bathing place is located in one of the parks.

\section{Conclusions}

The school as an educational institution at a cultural and historical site has a dual benefit to its school youth. This is particularly attributable to the transfer of the historical cognition to the next generations.

The manor building and the structure of the park of the last century has been distant from the historical original form. It contributed to the need for new facilities, subordinated to the interests of the schools, local residents, and tourists.

The surveyed center territories of the manors have a potential to evolve in accordance with the site's identity and implementation of complex solutions, raising the cultural quality of the cultural and historical site, which is enhanced by the start of the volumes of restoration work both for buildings and the park area.

The use of the area of the parks for the school needs most often is limited to the stadium, playground, and gym area. The park has a much wider range of opportunities that can be used by the school - to learn about plants, animals, history, art (color transitions, proportions), to draw and paint, listen to the birds, observe natural phenomena, and more. By restoring the historic manor garden, there is the opportunity to provide school children with healthy fruits. The Eco-school program is applicable to the placement of schools in manor buildings.

Estonia has a successful example where horses are currently kept in the stables of Ruila Manor, and riding classes are included in the school curriculum (an exhibition of schools in Estonian manors). In Estonia, a program for the restoration of manor schools has been implemented. In the ten years (2004-2015), 14 schools have been restored.

The rebirth of historical territories is largely due to the human activity or inactivity and natural processes. The municipality, the Ministry of Education and Science, and the Inspection for the Protection of Cultural Monuments are responsible for the development of the school territory in the historic manor houses.

\section{References}

1. Janelis, I. M. Latvijas muižu dārzi un parki. Rīga: Neputns, 2010.

2. Lancmanis I. Svitenes muiža = Schwitten; Bērsteles muiža = Gross-Bersteln. Rundāle: Rundāles pils muzejs, 2003. $85 \mathrm{lpp}$.

3. Lancmanis I. Kaucmindes muiža = Kautzemünde. Rīga: Rundāles pils muzejs, 1999. 52 lpp.

4. LPMA - Skolas pilīs un muižās [online] Latvijas piḷu un muižu asociācija (LPMA) sadarbībā ar www.google.com/maps [cited 12.11.2017] www.google.com/maps/d/viewer?mid=1qAH_hqDvfswEhqCrl0N7tnl ZRU\&hl=en_US\&ll=56.91389886596841\%2C24.543499500000053\&Z=17

5. Valsts kultūras pieminekḷu aizsardzības inspekcijas Pieminekḷu saraksts [online 12.11.2017] www.mantojums.lv /lv/piemineklu-saraksts/

6. Rubene, S., Lāčauniece, I. New structural elements and activities in historical gardens and parks. Scientific Journal of Latvia University of Agriculture. Landscape Architecture and Art. Jelgava: LLU, 2016, Vol. 5, No 5, p. 14-24. 
INFORMATION ABOUT AUTHORS:

Lolita Hercoga, Landscape Architect in Ltd. "Veido vidi". Master student (since 2016) in Latvia University of Agriculture, Department of Landscape Architecture and Planning. E-mail: hercoga.lolita@gmail.com Aija Ziemelniece, Dr.arch., Professor at the Faculty of Environment and Civil Engineering, Department of Landscape Architecture and Planning of the Latvia University of Agriculture, 22 Liela iela, Jelgava, Latvia, LV-3001. E-mail: aija@k-projekts.lv

Kopsavilkums. Pētījums aplūko vēsturisko muižu parku pielāgošanas iespēju skolu vajadzībām. Pēdējos simts gadus kopš skolu dibināšanas buma vecajās muižu pilīs vai kungu mājās, ir ienesta jauna funkcionālā slodze ne tikai vēsturiskajām ēkām, bet arī vecajam muižas parkam. Visbiežāk tas ir attiecināms uz parka kompozicionālās struktūras izjaukšanu, izvietojot jaunu celiņu tīklu, laukumus un atsevišşus elementus, kas nav pakārtoti vēsturiskajām skatu līnijām un ainavtelpas uzbūvei un ietver svarīgus kritērijus, lai nepazaudētu vēsturisko parku mērogu un atbilstību 18./19. gs. stilistikas tendencēm. Pēdējo simts gadu laikā tikai dažiem muižu parkiem ir veikta ainaviskā izpēte un dokumentācijas izstrāde, taču finansējuma trūkuma dēl projekts nav realizēts. Tas ir veicinājis muižu parkos veidoties atseviškāanm zonām ar nejaušǐbas raksturu, kuru tālāk papildina profesionalitātes trūkums parku uzturēšanā. Liela daḷa no perspektīvē darāmā darba gulsies uz pašvaldības vai privātīpašnieka pleciem. Ievērtējot statistiku, ka skolu skaits lauku teritorijās iet mazumā, iespējams, ka vēsturiskais mantojums nonāk apzin̄̄gu īpašnieku rokās, kas veltīs ne mazums pūlu veco parku uzturēšanā.

No 20. gadsimta divdesmitajiem gadiem, mainoties Latvijā politiskajām varām, līizi ir mainījusies arī muižu apbūves ansambḷu nozīme. Muižu ēkas un parki ir ieguvuši jaunu funkciju, kas veicinājis to izmantošanu mūsdienās. Aktivizējoties dzīvesveidam un sabiedrības vajadzībām, tas ir nolasāms dažādos jauninājumos muižas pils apkārtnē un parka teritorijā. Pārmainasas, kas nepieciešamas mūsdien̄̄gai parku izmantošanai, novērojamas parkos Latvijā, kaimiņvalstīs un Rietumeiropā. Daudzviet jaunie elementi labi papildina vēsturisko apbūvi, bet nereti tie ienes disproporciju, nerespektējot vietas kultūrvēsturisko kontekstu gan stilistiski, gan novietojuma ziṇā. Lai arī laika gaitā klāt nākušās funkcijas veicina teritoriju izmantošanu un apsaimniekošanu, taču ir vēl nopietns darbs veicams, lai rastu līdzsvaru starp kultūrvēsturiskā mantojuma saglabāšanu un mūsdienu tehnolog̣iju jauninājumiem.

Kā viens no grūtākajiem uzdevumiem ir sabalansēt skolas kā izglìî̄ibas iestādes obligātās mācību programmas prasības ar to novietojumu vēsturiskā muižas ēkā. Agrārās zemes reformas laiks Latvijā no 1922. gada noteica muižu apbūves ansambḷu pielāgošanu dažāda rakstura izmantošanai - skolai, sanatorijai, tautas namam, biedrībai, pienotavai, pagastmājai, nabagmājai. Visbiežāk muižu kungu māja vai pils tika pielāgota skolai, mainot ēkas plānojumu un veidojot piebūves. Saskan̄ā ar Latvijas Piḷu un muižu asociācijas datiem uz 2009. gadu Latvijas muižās pastāvēja 109 skolas. Uz 2009. gadu valsts nozīmes muižu centros darbojās 17 skolas, no tām līdz 2017. gadam skolas vēl izvietojas 13 pilīs (Beḷava, Dzelzava, Ezere, Jaunmuiža, Laidi, Marinzeja, Naukšēni, Ozolmuiža, Pope, Remte, Vandzene, Vilce, Zaļenieki). Muižu ēkas un parki veido kultūras un dabas mantojumu, ko vairākās vietās pozicionē arī kā tūrisma objektu. To apmeklē un izmanto skolēni un vietējie iedzīvotāji. 